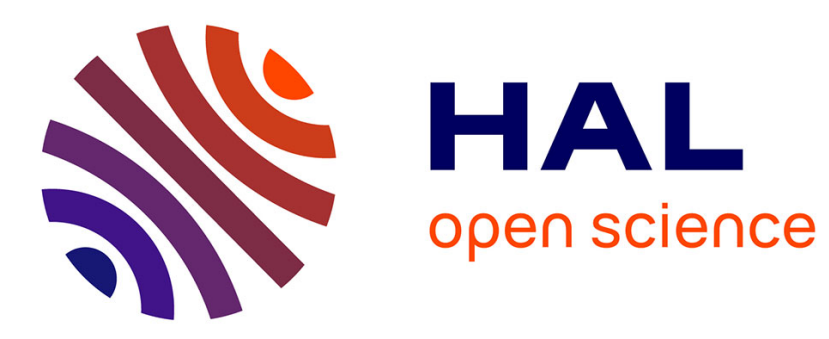

\title{
The Archaeological Landscape of Koh Ker, Northwest Cambodia
}

\author{
Damian Evans
}

\section{To cite this version:}

Damian Evans. The Archaeological Landscape of Koh Ker, Northwest Cambodia. Bulletin de l'Ecole française d'Extrême-Orient, 2010, 97-98, pp.91-150. 10.3406/befeo.2010.6130 . halshs-01885948

\section{HAL Id: halshs-01885948 \\ https://shs.hal.science/halshs-01885948}

Submitted on 2 Oct 2018

HAL is a multi-disciplinary open access archive for the deposit and dissemination of scientific research documents, whether they are published or not. The documents may come from teaching and research institutions in France or abroad, or from public or private research centers.
L'archive ouverte pluridisciplinaire HAL, est destinée au dépôt et à la diffusion de documents scientifiques de niveau recherche, publiés ou non, émanant des établissements d'enseignement et de recherche français ou étrangers, des laboratoires publics ou privés. 


\section{The Archaeological Landscape of Koh Ker, Northwest Cambodia} Damian Evans

Citer ce document / Cite this document :

Evans Damian. The Archaeological Landscape of Koh Ker, Northwest Cambodia. In: Bulletin de l'Ecole française d'ExtrêmeOrient. Tome 97-98, 2010. pp. 91-150;

doi : https://doi.org/10.3406/befeo.2010.6130

https://www.persee.fr/doc/befeo_0336-1519_2010_num_97_1_6130

Fichier pdf généré le 08/05/2018 


\title{
Résumé
}

Cet article offre une synthèse du déroulement des recherches et des résultats obtenus au cours de plusieurs années de prospections aériennes et de terrain sur le site de Koh Ker, province de Preah Vihear, dans le Cambodge du Nord-Ouest. Les principales découvertes concernent la mise au jour d'un système d'ingénierie hydraulique complexe comparable à celui d'Angkor au Xe siècle ; la reconnaissance de zones vraisemblablement dédiées à l'agriculture intensive pendant la période angkorienne ; une réévaluation des « routes » et des « enceintes urbaines » précédemment identifiées ; le taux de connectivité de la « route » septentrionale reliant Koh Ker à la route menant de Beng Mealea à Vat Phu ; la probable continuité d'occupation du site des débuts de la période historique jusqu'à la période post-angkorienne ; les preuves de l'effondrement du système de gestion des eaux ; et l'examen des données recueillies qui indiquent des changements à grande échelle de l'environnement local, dont l'altération de cours entiers de rivières.

\begin{abstract}
This article provides a summary of research activities and outcomes following several years of aerial and ground-based surveys undertaken at Koh Ker, in Preah Vihear Province in northwest Cambodia. Key findings include the discovery of a sophisticated and multi- period system of hydraulic engineering works bearing some similarities to that of Angkor in the 10th century ; the identification of areas likely devoted to intensive agriculture during the Angkorian period ; a re-appraisal of previously identified "roadways" and "city enclosures" ; evidence for domestic habitation and stone working sites ; the degree of connectivity of the northern "road" from Koh Ker to the Beng Mealea to Vat Phu road; possible continuity of occupation from early historic to post-Angkorian periods ; evidence for the collapse of the water management system ; and indications of large-scale changes to the local environment including alterations in the flows of entire river systems.
\end{abstract}




\title{
The Archaeological Landscape of Koh Ker, Northwest Cambodia
}

\author{
Damian Evans*
}

\section{Background and Rationale}

\section{Early Studies}

Aymonier's account of Koh Ker (fig. 1), based on field investigations undertaken in the 1880 s and 1890 s and published in 1900 , provides an overview of the principal monuments of the central area; notes the existence of the baray known locally as the "Rahal", along with its inlet and outlet; and provides a rudimentary map (fig. 2) that indicates the existence of a major embankment extending to the north from the main temple complex at Prasat Thom. In his treatment of Koh Ker, based primarily on architecture and inscriptions but also making use of anecdotal observations about the archaeological landscape and local environment, we see the emergence of several themes that have become a feature of all subsequent scholarship: the poverty of the natural environment of the area; the need for large-scale hydraulic engineering to maintain a substantial population; the peculiar orientation of the temples; the abundance of natural stone (both laterite and sandstone); the particular stylistic or chronological coherence of the body of architecture and inscriptions, attributable almost entirely to a single, relatively brief period in history; the notion of Koh Ker as an alternative, ephemeral capital of the Khmer Empire from 928-944 AD; and the theory that Jayavarman IV improvised a city within the wilderness at the beginning of that period, only to have his successor, Harshavarman II, abandon it once again to the forest (Aymonier 1900: 397-411).

Although Lunet de Lajonquière's subsequent (1902) treatment from a survey conducted in 1900 added considerable detail to the descriptions of the monuments and uncovered numerous inscriptions, it added little of analytical or historical value. His principal contributions were to point out that the orientation of the Rahal - designed, as it was, with large dykes on only the north and west, in order to capture natural flows with minimal engineering effort - may have been the determining factor in the orientation of the temples, and that two distinct groupings of temples could be identified based on orientation, indicating that the architectural periodisation was perhaps slightly more complex than Aymonier had proposed. Finally, whereas Aymonier (1900: 410) had been somewhat dismissive of the 10th century achievements of the Khmer at Koh Ker in the domains of art history, architecture and epigraphy, Lunet de Lajonquière (1902: 380) made a case for the significance of the site from an architectural and art historical point of view that has been amply justified in the century since (Jacques \& Lafond 2007: 103-133). Additionally, the estampages of inscriptions collected during his mission were later to provide the foundation for an important reappraisal of the history of the first half of the 10th century in Cambodia (Cœè̀s 1937-66, vol. I: 47-71).

\footnotetext{
* Department of Archaeology, University of Sydney.
} 


\section{Parmentier's Art khmèr classique}

Virtually all of the ideas of Aymonier and Lunet de Lajonquière were appropriated and extended to some degree by Parmentier (1939: 15-117), who, following some minor interventions in 1924, conducted an extremely thorough investigation of the monuments in 1929-1930 and continued to undertake work at the site well into the 1930s. Parmentier's focus was, like his predecessors, principally on the monuments and inscriptions, and throughout the course of his work he was able to double the number of known monuments at Koh Ker and record a number of additional inscriptions. By the time Parmentier's treatise on Koh Ker was published in 1939, Cœdès' survey of the inscriptions relating to Koh Ker had rendered the conventional interpretation of its timeline (i.e., 928-941 AD) problematic (1937: 47-71): K. 682 and K. 184, both from the principal temple of Prasat Thom, indicated that Jayavarman IV had claimed kingship of the Khmer by 921 $\mathrm{AD}$ at Koh Ker, in spite of inscriptional and architectural evidence from elsewhere that the royal capital remained at Angkor in that year. Furthermore, two inscriptions (K. 674 from Prasat Dan and K. 682 from Prasat Thom) indicated that at least some development at Koh Ker took place in the sixty years since its 'abandonment' as capital. Parmentier noted a series of temporal anomalies in Prasat Thom and adjacent temples that were indicative of renovation and modification, and concluded that these could be explained by the transition in 928 AD from Koh Ker as 'rival capital' to the unambiguous capital of the Khmer Empire, and a consequent imperative for more grandiose constructions. He argued that much of this project of expansion remained incomplete with the fall of Koh Ker as capital in $944 \mathrm{AD}$, and that only Prasat Andong Kuk could be definitively identified as being built outside of (post-dating, in this case) the reign of Jayavarman IV (Parmentier 1939: 111-114).

Perhaps the most innovative aspect of Parmentier's work was to undertake an analysis of the landscape surrounding the temples based on aerial prospection, encouraged no doubt by the high-profile successes of the aerial surveys that took place in the $1930 \mathrm{~s}$ over Angkor, and in particular the work of Goloubew, Marchal and Trouvé (Evans 2007). The result of that work was a detailed (and relatively accurate) map of the distribution of monuments (Parmentier 1939: 16) that included rice growing areas, ponds, watercourses, a hypothetical roadway that might explain the orientation of the monuments, and a series of rectilinear embankments to the north of Prasat Thom (fig. 3).

\section{Issues Arising from Parmentier}

This expansion of the methodology and scale of the study was accompanied by a more detailed (and somewhat contradictory) treatment of broader geographical aspects of Koh Ker's history. Parmentier, although he conceded that Koh Ker 'as a city' was very poorly delimited in space (1939: 19), nonetheless argued that the series of embankments north of Prasat Thom represented the partial remnants of an outer enclosure of the city, in spite of the fact that they are very similar in configuration to the banks of the Rahal - and, like the Rahal, had a watercourse emerging from them. Also, somewhat paradoxically, having defined the location of numerous fields of sandstone and laterite in the vicinity of the temples (and having even identified an Angkorian quarry at Trapeang Khna) he nonetheless suggested that difficulties in moving sandstone from the distant quarries of Phnom Tbeng or Phnom Kulen (fig. 1) may explain the unfinished state of sandstone temples at the 'fall' of Koh Ker in 944 AD. Furthermore, after pointing out that a road from Beng Mealea is known to proceed in the direction of Koh Ker, but admitting that he was unable to trace any connection. Parmentier omitted from his map the massive 
embankment extending northwards several kilometres from Prasat Thom that had been mapped and described by Aymonier (1900: 401-402) and instead traced an alternative, entirely imaginary road in a different place. Finally, having identified multiple potential outlets from the Rahal, he proposed that it was a critically important reservoir built for a program of rice irrigation which, in turn, was necessary to support a concentrated population in the harsh environment of Koh Ker. To move with so little evidence from 'the Rahal as a simple device for water storage with a spillway' towards 'the Rahal as a complex device for water storage and distribution across a field system' was a leap of faith and logic that anticipated, in many ways, the genesis of the controversial 'hydraulic city' hypothesis at Angkor over the next fifteen years (Goloubew 1941; Groslier 1952).

In spite of these issues, the map that Parmentier produced, as well as his descriptions of the temples, were of such a high quality that they remained the definitive account of Koh Ker and its environs for seventy years. ${ }^{1}$ In the published literature, Jacques' volume (2007) offers the definitive recent synthesis of scholarship on the provincial temple complexes and cities of the Khmer Empire, including a chapter on Koh Ker, and is instructive: the map of the site (fig. 4) is in fact Parmentier's map with only the font of the labels changed, and almost all of the description and interpretation of the temples derives from Parmentier. The main contribution of Jacques' treatment is to reappraise the nature of Jayavarman IV's kingship prior to 928 AD in light of the evolving debate about the universality of Khmer kingship, and an important new interpretation of the temple of Andong Kuk, which, following a visit to the Koh Ker by Pottier and Jacques, has been identified as a hospital chapel typical of the era of Jayavarman VII in the 12th to 13 th centuries (Jacques \& Lafond 2007: 133; Christophe Pottier, pers. comm.). ${ }^{2}$ Indeed, Parmentier's L'art khmèr classique, and the work of Aymonier, Cœdès, and Lunet de Lajonquière that it extends, informs virtually all of the standard histories of the Khmer as can be seen by the consistent references their notions of hydraulics, environment, urbanism, demography and decline at Koh Ker (Briggs 1999 [1951]: 117; Chandler 2000: 40-41; Dumarçay \& Royère 2001: 4; Groslier 1962: 106,112; Higham 2001: 70-71).

\section{Recent Research Context}

In 2006 and 2007 the Apsara National Authority conducted the very first modern scientific excavations at Koh Ker, consisting of small test excavations at three different sites in the central temple precinct under the direction of Ly Vanna (Ly, Ea, Loeu et al. 2010). These sites were: the bank of the artificial pond known as Trapeang Sre; on the north bank of the Rahal, at the laterite outlet identified by Aymonier; and a possible canal feature in the vicinity of the structures $200 \mathrm{~m}$ east of the eastern gopura of Prasat Thom, which the authors give the name Prasat Srut (called Monument A by Lunet de Lajonquière). The excavations were also accompanied by pedestrian surveys designed

1. In some cases, Parmentier's account is likely to remain definitive: In a visit to Koh Ker in 1952 , Boisselier remarked upon the degree to which the temples had suffered both from a lack of care and from the depredations of people in search of iron objects in the two decades or more since Parmentier's landmark study; ironically, the iron objects in question were largely elements put in place by Parmentier to prevent further degradation of the temples and statuary (EFEO Archives, Paris: Carton 1, Dossier V: Boisselier, Jean. Activités scientifiques. Rapport sur la mission exécutée dans le groupe de Koh Ker et les groupes d'Angkor-Roluoh entre le l't et le 19 avril 1952).

2. In unpublished archives at the EFEO in Paris, Boisselier in 1952 identified the temple as belonging to the Bayon period on stylistic grounds, but did not recognize it as a hospital chapel (EFEO Archives, Paris: Carton 1, Dossier V: Boisselier, Jean. Activités scientifiques. Rapport sur la mission exécutée dans le groupe de Koh Ker et les groupes d'Angkor-Roluoh entre le l'or et le 19 avril 1952). 
to clarify some aspects of the topography to the east and north of Prasat Thom (Llopis 2009; Ly, Ea, Loeu et al. 2010). Trenches at Trapeang Sre revealed minimal evidence for occupation in the form of earthenware fragments, possibly discarded from households located on or near the bank of the pond; however, the trenches to the north of Prasat Srut revealed a substantial ceramic sequence $1.5 \mathrm{~m}$ deep consisting mostly of roof tiles, but also including fragments of glazed stoneware pots and bowls and, at the lowest levels, pre-Angkorian earthenware. Perhaps the most interesting excavation of the three was that of the north exit of the Rahal, which revealed multiple stages to the construction of the baray. The authors also note a complex and highly varied topography to the north of the Rahal, including a broad depression, and a distribution of pre-Angkorian ceramics and ferric pisoliths immediately to the north of Prasat Thom, and conclude generally that the Rahal has undergone several stages of renovation and that the central Koh Ker area may have been inhabited (although not necessarily continuously) since the proto-historic or pre-Angkorian period.

Clearly, therefore, a major re-evaluation of the history and archaeology of Koh Ker is long overdue. In addition to the pioneering work at Koh Ker undertaken by Apsara, recent studies have facilitated considerable advances in our understanding of settlements elsewhere in Cambodia (Evans 2007; Fletcher \& Pottier 2002; Gaucher 2003; Pottier 1999; Potticr, Bolle, Llopis et al. 2005; Stark 2006); closer consideration of the longneglected Khmer-language inscriptions (which are abundant at Koh Ker) have resulted in new perspectives on pre-Angkorian and Angkorian societies (Lustig 2009; Vickery 1998); advances in scientific dating techniques permit high-resolution dating of temples, archaeological landscapes, and the palaeoenvironment (Buckley, Anchukaitis, Penny et al. 2010; Penny, Pottier, Fletcher et al. 2006; Penny, Pottier, Kummu et al. 2007; Sanderson, Bishop, Stark et al. 2003; Wilson, Carter, Hall et al. 2009; Zoppi, Barbetti, Fletcher et al. 2004); advances in geospatial sciences such as remote sensing and GIS can reveal previously undetected features, even beneath forest canopies, and allow the management and analysis of vast quantities of data (Evans, Pottier, Fletcher et al. 2007; Fletcher, Johnson, Bruce et al. 2007; Lustig, Evans \& Richards 2007; Moore 2000); and new approaches to traditional topics in the archaeology and art history of Cambodia have revealed important new insights into the development of Khmer culture across time and space (Hendrickson 2007; Polkinghorne 2007). Combined, all of these approaches have the potential to clarify the historical development of Koh Ker, which will in turn have implications for our understanding of Khmer history in the 10th century and, more broadly, of the complex interactions between people and their environment in early Cambodia.

This archaeological potential was summarised in a report produced in cooperation with the Hungarian-Cambodian Koh Ker Project (Evans 2009), accompanied by a new (and somewhat preliminary) treatment of various spatial and chronological issues surrounding the site of Koh Ker, and a series of suggestions about how to move toward a fuller understanding of the archaeological landscape of the site. The methodological foundation of this research agenda was a major revision of Parmentier's 1939 map of Koh Ker, while the overarching aim of the program has been to uncover, document and analyse the archaeological context of the well-known monuments across a broad area of the landscape, in order to elucidate aspects of the development of urban form, industry, agriculture, water management, infrastructure and environment associated with the temple complex throughout the Angkor period. 


\section{Recent Research}

In the years since 2009 , a measure of this potential has been realised by various international teams, working both jointly and independently. The University of Sydney, the Apsara National Authority and the Hungarian team have been working jointly on the analysis of ceramics and also in the domain of remote sensing, culminating in an airborne laser scanning (lidar) mission in April 2012 and the production of a new archaeological map of the site, presented here for the first time. Furthermore, under the direction of Éric Bourdonneau of the École française d'Extrême-Orient, a Franco-Khmer team has been conducting a series of excavations on the large artificial mound immediately to the west of the Prang/Prasat Thom enclosure, and providing important new insights into aspects of Koh Ker's architecture, epigraphy and art history (Bourdonneau 2011). Also in partnership with Cambodian researchers, the Hungarian and Japanese teams have made a severalyear commitment to topographic survey, excavations and epigraphic and architectural studies which promise to considerably enhance our understanding of Koh Ker's history, and in particular have contributed to a much expanded knowledge of the distribution of archaeological sites on the ground, and an excellent corpus of documentation on those sites (Mizoguchi \& Nakagawa 2011; Renner 2011; Vajda 2010). Meanwhile, two important $\mathrm{PhD}$ theses have been produced on Koh Ker (Chen 2011; Sato 2010), and a new volume on the epigraphic corpus of Koh Ker (Chhom 2011).

In spite of the volume of work, however, much of this new material has remained in unpublished theses and reports with limited distribution, and very few peer-reviewed publications that deal with Koh Ker in any detail have made it to press in recent years. What follows, therefore, is a further contribution to this multinational effort, involving not only the presentation of a previously unpublished archaeological map of Koh Ker, but also an attempt to summarise and synthesize recent work and reconcile it with features newly identified as a result of the mapping work. Located specifically in the domain of landscape archaeology, this paper aims to provide a spatial framework for further and more detailed analyses on the ground at Koh Ker in the future. It forms one component of a broad, comparative study of early Khmer urbanism that includes similar studies at sites such as Angkor, Banteay Chhmar, Preah Khan of Kompong Svay, Sambor Prei Kuk, Beng Mealea, and Oudong/Lovek (Evans 2010; Evans \& Moylan 2013; Evans, Pottier, Fletcher et al. 2007; Evans \& Traviglia 2012). A great deal of work remains to be done at Koh Ker; however, a number of provisional results and hypotheses - including an updated map of the site and its environs - are presented here.

\section{Methodology: Remote Sensing and Archaeological Survey}

\section{General Methodology}

The methodology used for this study was based on that used by the Greater Angkor Project for mapping approximately two thousand square kilometres of the archaeological landscape around Angkor from 2001 to 2007 (Evans 2007: 144-203), a methodology which was based largely, in turn, on Pottier's (1999) mapping work on the southern and central areas of Angkor itself (for a summary, see Evans, Pottier, Fletcher et al. 2007). The method has proven successful in identifying habitation areas in the form of mounds and ponds, and other archaeological features such as canals, roadways, reservoirs, moated temple sites (often with no architectural remains on the surface), as well as pre-modern field systems. Analysis is based firstly on the collection, digitization and evaluation of all of the available historical evidence. Then, an extensive collection of remotely sensed 
data is acquired and used to identify subtle surface variations in topography; vegetation type, density and geometry; soil moisture and chemistry; as well as the spatial logic and 'surface stratigraphy' of related artifacts on the archaeological landscape. Verification derives from pedestrian survey and the analysis of surface scatters of ceramic, brick and stone debris and the general confirmation of observations derived from remote sensing; this is done systematically on the ground, where circumstances permit, or otherwise opportunistically based on an evaluation of the features most likely to be of archaeological interest. In the case of the Greater Angkor Project, fifteen years of invasive methods such as coring and excavation, as well as non-invasive techniques such as ground penetrating radar (GPR), have also been employed in order to evaluate the effectiveness of the method for identifying subsurface remains (Fletcher, Penny, Barbetti et al. 2006; Fletcher, Penny, Evans et al. 2008). The method of surface data collection and mapping are described in detail elsewhere (Evans 2007: 144-203), but the particular circumstances of Koh Ker have required some adaptations in the methodology and these are described here.

\section{Methodological Adaptations at Koh Ker}

One of the key challenges presented by Koh Ker is that of forest cover. Although remote sensing has proven highly effective at Angkor in identifying archaeological features in areas now given to scrubland, agriculture and urban development, forest cover remains a serious impediment to most forms of aerial archaeological prospection. The open deciduous woodland of Koh Ker, however, presents much less of a challenge than areas such as the Kulen, for example, with its dense, canopied forest. This is particularly true for dry-season data acquisitions of data over Koh Ker, where reduced foliage and the systematic burning of undergrowth by local residents results in marked improvement of the visibility of the ground from above. Although all remote sensing datasets used in the analysis were therefore acquired during the dry season, it should nonetheless be pointed out that the results of the mapping may be significantly less accurate or complete than the maps produced of the lowlands of greater Angkor. At Angkor, the study area could be usefully defined by using the watersheds of all of the fluvial resources manipulated by the successive capitals at the site, as loosely defined by previous studies (Groslier 1979; Jacques 1978). Due to the lack of previous information on the extent of hydraulic works at Koh Ker, however, the study area was arbitrarily defined by the extent of the available remote sensing data and the need to extend Parmentier's map to include the quarry fields of Srayang, to the south, and the Beng Mealea to Wat Phu road, to the north (Parmentier 1939: 16; Hendrickson 2007).

\section{Primary Sources}

The principal remote sensing datasets used for analysis, in order of importance (i.e., usefulness), were: A series of 1:25,000 scale black and white aerial photographs, in stereo pairs, acquired by the FINNMAP company in the dry seasons of 1992 and 1993; a $1 \mathrm{~m}$ resolution multispectral and panchromatic IKONOS satellite image acquired in January 2001 ; a $0.5 \mathrm{~m}$ resolution TerraSAR-X radar image acquired on May 8th 2009; a series of 211 oblique aerial photographs taken by the author in the course of a low-level aerial survey in a microlight aircraft April 2nd 2009. Background datasets were derived from other sources for features such as roads (Hendrickson 2007), topography (Japan International Cooperation Agency 1999) and temples (Phann, Chrin, Chan et cl. 2007; Shimoda \& Sato 2011). Finally, high-precision airborne laser scanning (lidar) data acquired in April 2012 were used to verify and correct the mapping of the most archaeologically signifi- 
cant features at Koh Ker, although at the time of publication no complete and systematic analysis of the lidar data for Koh Ker had been achieved, and this task is expected to take some years to complete and to verify on the ground. ${ }^{3}$

As with Angkor, the existing 1:50,000 scale hydrological dataset for the area (Japan International Cooperation $\Lambda$ gency 1999) was deemed inadequate for a thorough evaluation of the nature of water flows within the study area, and these were manually digitised at a nominal scale of 1:5,000. Based on a review of hundreds of geolocated photos taken in the course of field surveys, a contemporary forest cover classification was also performed using a supervised classification in ENVI of the multispectral IKONOS data based on three broad categories: open land (including bare ground, grassland, shrubland, urban and built, and cropland); woodland; and forest. Additional feature types unmapped at Angkor have also been included in the new map of Koh Ker presented here. These are linear traces of pre-modern field walls; seasonally inundated areas such as swamps, broad channels and meander floodplains adjacent to streams; surface scatters of ceramics, excluding roof tiles, in the immediate vicinity of temples; and surface scatters of laterite rubble. Additional detail on primary sources and survey and mapping methodology can be found in previous reports (particularly Evans 2009). The outcome of the mapping project ${ }^{4}$ is presented as fig. 6 , representing a study area of $167 \mathrm{~km}^{2}$.

\section{Landscape, Environment and Agriculture}

\section{Introduction}

From the earliest surveys of the site of Koh Ker, the issue of the poverty and barrenness of the landscape has been a consistent theme in the literature (Aymonier 1900: 397411; Briggs 1999 [1951]: 117; Jacques \& Lafond 2007: 107). Because this idea is used to underpin several historical assumptions about Koh Ker - the need, for instance, for massive water storage devices to support a large population throughout the dry season - it needs to be considered critically. There are two major components to the arguments: on the one hand, that there is little available water in the area; and on the other hand, that the soil is impoverished and that the land is therefore unproductive.

3. For the purposes of this paper, most attention was focused on a final elaboration of the linear structures to the east and to the north of the ceremonial centre of Koh Ker, with a view to finally resolving certain questions about the functioning of the water management system (see the section on water management below). One notable omission, compared to the previous map published by Evans (2009), is the large mound complex to the north of Prasat Thom; this was deemed to be a possible extension of a natural ridge, and could not be definitively classified as anthropogenic.

4. A note on names: there is substantial variation in the names of temples, and in their transcription into English, in the revisions of Parmentier's map (fig. 3, fig. 4, fig. 5), and some errors in naming and positioning have been introduced in the recent maps (fig. 5). I have generally followed the names given by Shimoda and Sato (2011) to the temples. Some confusion also exists about the names of streams and rivers in the area of Koh Ker, and in particular, the very important eastward flow that stretches across the northern reaches of Koh Ker. Most 20th century topographic maps refer to its major tributary to the west as the Stung Traling, but after this is joined by the O Sre Prang it is unclear what name it takes until its confluence with the O Tray, after which point it tends to be labelled the Stung Rongea. In spite of this, numerous local informants were unable to specify a name for the river (although some correctly volunteered that it was a tributary of the Stung Sen). For the purposes of this study it is called the Stung Rongea, but this may be subject to revision. 


\section{Palaeoclimate}

Firstly it should be noted that all of these observations about the palaeoenvironment of Koh Ker are anecdotal, highly subjective and based on very recent environmental conditions and observations. Until recently, high-resolution reconstructions of palaeoclimate during the late Holocene were frustratingly rare for mainland Southeast Asia, with the highest-resolution proxy records in the vicinity of northern Cambodia deriving from treering data in Northern Vietnam extending back only some five centuries (Sano, Buckley \& Sweda 2009), and with only broad generalisations possible beyond that period (Stark 2006). While these data provided some insight into the climatic conditions concurrent with the demise of Angkor as the capital of the Khmer Empire in the 15th century (Buckley, Anchukaitis, Penny et al. 2010), they provided little of use for an analysis of the 10th century, beyond the identification of occasionally occurring 30-year 'megadroughts' in the last 500 years that could conceivably be a pattern extending several centuries further back in time (this remains purely hypothetical at this stage). New research, however, indicates that the rise of Koh Ker as an alternative capital to Angkor may have coincided with the beginning of the Medieval Climate Anomaly, a period starting in (perhaps) the 10 th or (at the latest) the early 11 th century AD that was associated with warmer temperatures and higher rainfall in mainland Southeast Asia, and which saw the florescence of several inland, agrarian civilisations across the region (Lieberman \& Buckley 2012). Is it possible that additional rainfall may have mitigated the dry-season advantages enjoyed by 'lowland' Khmer centres like Angkor, with its high water table and technologies of floodplain management, and facilitated a brief ascendancy of more successful 'upland' populations in places Koh Ker? Once again, unfortunately, the temporal coverage of the high-resolution climate proxy data falls frustratingly short, and the question must remain unresolved unless that record can be extended back perhaps a century further.

In any case, in the absence of higher resolution data, the working assumption for the time being may therefore be that patterns of rainfall in the conventional 'era of Koh Ker' were indeed generally quite similar to those today, or higher; however, there remains the possibility, especially given the very circumscribed period in which Koh Ker was the 'capital' of the Khmer Empire, that its major period of development was characterised entirely by severe drought. In terms of land cover, although the general assumption must be that the Koh Ker area was forested at the end of the second millennium AD, research has shown that many areas in mainland Southeast Asia have undergone cyclical changes between forest and grassland; on the current evidence, however, this seems likely to have been produced by anthropogenic clearing more than through purely natural phenomena (Bishop, Penny, Stark et al. 2003; Penny, Pottier, Fletcher et al. 2006; Stark 2006: 412). Fortunately, at Koh Ker there is clear potential to come to terms with the local and regional land cover relatively quickly, and at high resolution, using the techniques employed by other research teams in Cambodia (Bishop, Penny, Stark et al. 2003; Penny, Pottier, Fletcher et al. 2006; Penny, Pottier, Kummu et al. 2007). Again, this work remains to be done. Let us assume for the sake of argument, as Claude Jacques does (2007: 107), that rainfall and natural land cover at Koh Ker in the 10th century were more or less consistent with what is observable today.

\section{Soil Quality and Agriculture}

On the issue of soil quality in the Koh Ker area relative to that of the Angkor area, with a view to assessing relative suitability for rice agriculture, detailed studies also remain to be completed. The principal sources at this stage are Croker's (1962) general 
classification of soil types, two edited volumes on rice production and soil classifications in contemporary Cambodia (Nesbitt 1997; White, Oberthür \& Pheav 1997) neither of which specifically address Preah Vihear Province - and very coarse-resolution spatial datasets of soil types and suitability for rice agriculture produced by the Mekong River Commission (2002) and by the Cambodian $\Lambda$ gricultural Research and Development Institute in Phnom Penh. Nonetheless, even on the basis of the available data, it is clear that the rice-growing potential within the Koh Ker study area is indeed poor relative to greater Angkor area. Although both areas are generally characterised by acrisols with relatively low rice-growing potential, the floodplains of the Tonle Sap near Angkor are characterised by substantial bands of fluvisol and gleysol (Mekong River Commission 2002), rich with alluvium, which considerably enhances the productive potential of the Angkor area. According to White and Oberthür's (1997) classification, the greater Angkor area, from south to north, consists of lacustrine floodplains graduating to expansive floodplains and relatively low-lying alluvial terraces (and including some meander floodplains between Angkor Thom and Banteay Srei), creating a hydrological regime highly conducive to the productive rice agriculture that characterises much of Cambodia's lowlands (Nesbitt 1997). Koh Ker, on the other hand, has a landscape characterised by rolling hills and more variable topography; although the major temples are located between 70-80 m AMSL and the landscape is by no means mountainous, altitude varies within the study area within the range of $50-160 \mathrm{~m}$ and much of the terrain - particularly between the Rahal and Srayang - is amenable only to the classic 'upland' model of Cambodian agriculture (Nesbitt 1997). In this scheme, the majority of land is suitable only for swidden rice cultivation that is highly dependent on rainfall and subject to rapid runoff, and only smaller areas - usually small meander floodplains adjacent to streams are seasonally inundated and can be devoted to bunded field systems that capture surface runoff, allow more precise control of critical water levels, and help to ameliorate annual variability in rainfall.

Such areas represent only $21.65 \mathrm{~km}^{2}$ of the study area, or approximately 13 percent, but there is abundant evidence of manipulation of these resources during the Angkor period. The new mapping work presented here reveals that numerous small embankments were built laterally across seasonally inundated and meander floodplains areas in order to capture their flow, similar to the 'upland' system of water management described in the Phnom Kulen area of Siem Reap (Boulbet 1979; Van Liere 1980).

In other parts of the study area, however, and particularly across a $\sim 20 \mathrm{~km}^{2}$ stretch of the landscape between the main temples of Koh Ker and the small river $5 \mathrm{~km}$ to the west, remote sensing has revealed evidence of the remains of a pre-modern walled field system beneath the light woodland which now covers the area. This system is not only in seasonally inundated areas but in places extends onto the low-lying terraces beyond, and is clearly designed to take advantage of rainfall and surface runoff across a much broader area. In this sense, the majority of the study area resembles the transitional lowland-tohighland agricultural landscape of Angkor between the central temples and the Phnom Krol, Phnom Kbal Spean and Phnom Kulen massif to the north, which we know to have been populated and almost certainly cultivated to some extent during the Angkor period (Evans 2007). The extent to which the current picture of Angkorian rice field remains at $\mathrm{Koh} \mathrm{Ker}$ is accurate, or whether there were more extensive field systems which remain obscured by the woodland, will only be resolved through the further analysis of highresolution topographic data derived from the 2012 lidar data, which has the capability 
to detect subtle height variations on the forest floor. This work is ongoing at the time of publication.

\section{Productivity and Population}

On the current evidence, then, was large-scale hydraulic engineering therefore actually "necessary" to support a significant population at Koh Ker? The first thing to note is that there are now indications that the area was inhabited (although not necessarily continuously) across a span of at least a thousand years (see below), from perhaps as early as the proto-historic period ( $\sim 500 \mathrm{AD}$ or earlier) until the present day, and that there is no clear evidence at this stage that large-scale hydraulic works were undertaken outside of the 'classical' Angkorian period of the 9th to 15 th centuries (see below). It may nonetheless be informative at this point to make some very rough calculations as to the population carrying capacity of the landscape, as has been done for Angkor (Acker 1998; Groslier 1979; Lustig 2001; Pottier 2000b) in order to evaluate the premise that large-scale hydraulic infrastructure was needed to support the (presumably) large population associated with a capital of the Khmer Empire. Allowing, after Acker and Pottier, that all of the seasonally flooded areas within the study area $\left(21.65 \mathrm{~km}^{2}\right.$, or $\left.2165 \mathrm{ha}\right)$ were cultivated during the wet-season, they are capable of providing enough rice to support 15,800 people. ${ }^{5}$ If that area werc expanded to include lowland areas for which we currently have evidence of pre-modern rice agriculture occurring on terraces beyond flood zones (approximately an additional $2000 \mathrm{ha}$ ), it might support an additional population of perhaps $11,000 .^{6}$ Although it makes an appreciable contribution to modern agricultural output in the Koh Ker area, the role of upland rice agriculture is unlikely to have been very significant in pre-modern Cambodia due to issues of yield, soil fertility, vulnerability to drought and the need for constant crop rotation (Nesbitt 1997: 75-80). However, if an additional 2000 ha/year within the study area were devoted to this form of agriculture, one might expect enough rice to support perhaps an additional 6800 people. $^{7}$

The total of these very rough and extremely provisional estimates is that the land within the study area - all of which it should be remembered is $<8 \mathrm{~km}$ and within a two hour walk of Prasat Thom - even on conservative estimates had the capability of supporting a population of more than 30,000 people without large-scale engineering works such as the Rahal; if (again conservatively) only half of these were of working age, it would have provided a pool of 15,000 people to draw upon during the dry season in order to devote to civil engineering such as temples and hydraulic constructions, which is, of course, a not insignificant number of labourers especially given the relatively modest dimensions of the engineering achievements at Koh Ker, the Prang notwithstanding.

What contribution would the Rahal have made? Here again, a precise calculation of its water-carrying capacity awaits further study of the lidar data. However, topographic surveys undertaken by Sato (2010:100-102) along the eastern edge of the reservoir permit a rough estimation. According to that study, the distance between the top of the wall (at $\sim 80 \mathrm{~m}$ in height) and the bed of the reservoir is a maximum of $7 \mathrm{~m}$ at the (northern) down slope

5. Based on a figure of 1.46 tonnes/ha for irrigable areas with bunded field systems subject to careful management of water resources, with each tonne feeding 5 people/year, after Acker and Potticr.

6. Based on a figure of 1.1 tonnes/ha for wet season for conventional lowland rain-fed rice in bunded field systems, after Acker and Pottier.

7. Based on a figure of 0.68 tonnes/ha alter Groslier. 
end, with a $3 \mathrm{~m}$ difference at the southern (up slope) end. ${ }^{8}$ Considering that the eastern side of the reservoir abuts a westward slope at a height of $-80 \mathrm{~m}$, it is conceivable" that the reservoir was filled from this direction to a maximum height of $80 \mathrm{~m}$. Given then that the interior dimensions of the Rahal are approximately $1100 \times 520 \mathrm{~m}$, and assuming a uniform slope in its floor from the north dyke to the south dyke, it is possible to calculate that the Rahal, in its final stage, was capable of containing at the very most $2,574,000 \mathrm{~m}^{3}$ of water. ${ }^{10}$ Following Acker (1998), if we assume an approximate relationship between a cubic metre of irrigation water and a square metre of irrigable land, the total amount of extra population to be supported by a construction such as the Rahal would be less than 2000 people. ${ }^{11}$ So much, then, for Parmentier's prototypical 'hydraulic city' hypothesis for Koh Ker, at least based on the carrying capacity of the Rahal.

It should also be noted that the red earth region of Srayang village is highly productive from an agricultural point of view, and that large tracts of land in this area are currently devoted to banana plantations and intensive year-round farming. Given the presence of numerous Angkorian remains in this area, including the temple of Prasat Dei Khmau and an extensive laterite quarry, it is reasonable to assume that it was also intensively exploited in support of the population at Koh Ker, although this awaits further archaeological investigation.

\section{Water Storage and Availability}

There remains another issue, which is the availability of water, relative to Angkor/ Siem Reap, for regular rain-fed rice agriculture in the wet season and also of course for the sustainability of a given population throughout the dry season. In terms of annual rainfall, although here again data are scarce, it should be recognized that the Koh Ker area, and Preah Vihear Province generally, receive 20 to 25\% more rainfall than the Angkor area (Mekong River Commission 2005:17; Nesbitt 1997: 45). In this sense, Koh Ker cannot be considered to be a 'dry and inhospitable zone' relative to Angkor according to the conventional wisdom. Moreover, although Koh Ker is well-drained due to its considerable surface slope, and although the water table is substantially lower than Angkor (where ponds excavated to a depth of less than $5 \mathrm{~m}$ are able to maintain water year-round in many areas), field surveys have shown that some of the numerous artificial ponds at Koh Ker, including Trapeang Khna, Andong Preng and the moat of Prasat Thom, can retain water until the very end of the dry season. This can be attributed to the substantial depth to which they have been excavated, and perhaps also to the relatively impermeable sandstone substrate which underlies some of the Koh Ker area at a depth of only 2-3 m

8. Contrary to assertions by Aymonier, Parmentier and others, the southern dyke of the Rahal does exist (as does an eastern dyke) but is difficult to discern in some sections. I would suggest that Sato's limited survey of the southeast corner showing a depth of $4 \mathrm{~m}$ inside the baray is therefore somewhat misleading; in fact, there is a quite small and unusually deep depression exactly in this corner (probably in fact a ditch resulting from excavating earth to build the baray wall), the base level of which cannot extrapolated across the entire reservoir. I will nonetheless use the generous figures suggested by Sato"s survey in order to obtain a 'maximum possible' figure for productivity from the reservoir.

9. But of course highly improbable from an engineering point of view, given the volume of water and the structural implications of a 100\% full reservoir for the main dam wall at the north, which is made primarily of earth. Nonetheless, I will again use the figure that provides a more generous estimate of agricultural yield.

10. That is, a north-south profile of $4950 \mathrm{~m}^{2}$ multiplied by the east-west width of $520 \mathrm{~m}$.

11. Based on a figure of 1.46 tonnes/ha for irrigable areas with bunded field systems subject to careful management of water resources, with each tonne feeding 5 people/year, after Acker and Pottier. 
(Carò, Douglas \& Im 2009: 3; Moriai, Matsumura \& Akama 2002; see however Parmentier 1939: 20 in relation to Andong Preng). Moreover, although there are no permanent water sources at Koh Ker to rival the Tonle Sap, there are numerous potentially permanent, natural bodies of water in the area. Springs in the vicinity of Srayang village feed a reservoir there and a small stream and wetland near Prasat Dei Khmau. Also, although all of the streams within the study area are seasonal in terms of flow, large stretches of the Stung Rongea and its tributaries maintain significant bodies of standing water throughout the dry season. In the IKONOS image of January 2001 , virtually all of the $16 \mathrm{~km}$ length of the Stung Rongea in the study area contained water, with drainage effectively prevented by occasional sandstone outcrops from the streambed; many of these water bodies to the north of Koh Ker were verified as still standing in March and April of 2008 and 2009, by which time occasional rains were already heralding the onset of the next wet season. All of these water resources are within a few hours' walking distance of the center of Koh Ker (the nearest is $4 \mathrm{~km}$ away) and could conceivably have supported a very substantial population without the development of additional water control systems.

Finally, as mentioned above, it is clear from the new mapping work that a large number of small earthen dams were erected across the valleys created by the varied topography of Koh Ker, as part of a widespread and system of capturing seasonal flows that bears many similarities to the well-documented system of water control in Phnom Kulen. The problem at Koh Ker, it seems, was not one of water supply: rather, it was a problem of overcoming the inherent topographic limitations of the area, in which water-instead of flooding the landscape - rapidly drained away into steep valleys and thence into tributaries of the Stung Sen. Although fundamentally different from the lowland system of Angkor, which revolved around trapping floodwaters and excavating ponds down to the water table, it is nonetheless likely to have been quite effective if applied on a large enough scale at Koh Ker, and certainly capable of supporting a very substantial population.

It needs to be reiterated that these population figures are highly provisional and are designed only to give a very approximate indication of the population carrying capacity of the landscape within the study area. The study area is, as mentioned, almost entirely arbitrary; there is at this stage there is no clear idea of the 'economic catchment' across which the royal centre at Koh Ker appropriated natural resources or labour; no clear indication of the degree to which the population in and around the temples was permanent/ sedentary or fluctuated seasonally based on an influx of a transient/mobile population from elsewhere during the dry season; no clear data from the inscriptions about the degree to which specialization and stratification, or gender roles within the society created a class of 'non-producers' who cannot be included in counts of builders or farmers; and no archaeological evidence of the extent to which the agricultural potential of the landscape of the area was actually realized. Nonetheless, it is clear that, if the environmental conditions in the Koh Ker area were not radically different to those of the present day, traditional assumptions about the landscape there not being able to support a substantial population - and in particular, deterministic links between the natural environment and hydraulic engineering - are deeply problematic.

\section{Industry}

\section{Ceramics and Kilns}

Unlike the other major 'city' of Preah Vihear Province, Preah Khan of Kompong Svay, or the road that leads to it from Angkor (Hendrickson 2007), there is little archaeo- 
logical evidence at this stage to suggest that Koh Ker was involved in large-scale industrial production of any kind of goods or materials, whether it be ceramics, iron products, or stone. No kilns have been located within the study area, or, to my knowledge, within Preah Vihear Province, although a large number have been identified elsewhere in northwestern Cambodia and in adjacent areas of what is now Thailand (Ea, Chhay, Chap et al. 2008; Hendrickson 2008). A significant scatter of surface ceramic debris at Prasat Boh Lohon - itself unusual for Koh Ker, where sherds are not commonly seen in very large quantities on the surface - seems unlikely to indicate the existence of a kiln at the site, due to the heterogeneity of the pieces (including imported wares from China dated 14th century or later), the absence of any wasters and of the mounded features that normally indicate buried Angkorian kilns, and the fact that the quantity of sherds on the surface is substantially less than at other kiln sites that have been observed.

\section{Metals and Metalworking}

Jacques (2007: 107) suggests that the hegemony of Koh Ker may have extended south to the well-known iron producing area of Phnom Daek and Preah Khan of Kompong Svay. Although an intriguing possibility, there is little evidence to support the notion at this stage. Koh Ker is $40-50 \mathrm{~km}$ from this area and there are no riverine connections between the two - Koh Ker and Preah Khan of Kompong Svay are in fact located on two completely different river catchments leading into the Tonle Sap - and no evidence of any road linking the two sites. Although the development of Preah Khan of Kompong Svay tends to be dated two centuries later that the royal capital at Koh Ker, there is no reason at this stage to believe that it too does not have a long and complex history of occupation, nor any reason to suppose that the wealth of Koh Ker was predicated on the exploitation of such a distant resource. Llopis (2009) also documents the existence of ferrous nodules north of Prasat Thom at Koh Ker and mentions reports from villagers of finds of iron implements in the context of pre-Angkorian ceramics, and notes the possibility of early iron works at the site; however, ferric accretions are common in the soils around Koh Ker (for example the great laterite fields of Srayang) and there are, to my knowledge, none of the classic signs of iron smelting (ceramic tuyeres, slag, or large mounds indicating buried furnaces) within the study area. Jacques' hypothesis, finally, is based on the idea that an independently wealthy and influential Koh Ker cannot possibly be explained given its marginal environmental conditions, which as I have argued above is probably false.

\section{Stone and Quarries}

There are two resources in which Koh Ker is undeniably rich, and these are sandstone and laterite, which often protrude in large outcrops, with sandstone prevalent in the area around the major temples of Koh Ker and abundant laterite in the vicinity of Srayang and to the west of Prasat Bei. However, numerous sandstone quarries have been identified in the Phnom Kulen area, in the Khorat plateau of Thailand, in Champassak in Laos, and in the Banteay Meanchey, Kompong Cham, Kratie, Siem Reap and Preah Vihear provinces of Cambodia (Boulbet 1979; Carò \& Im 2012; Moriai, Matsumura \& Akama 2002; Parmentier 1939; Phann, Chrin, Chan et al. 2007; Rocks 2009 and author's field investigations at Koh Ker and Banteay Chhmar). Although it seems clear that temple builders sourced stone from a number of different quarries for a given temple based on particular architectural or decorative requirements (Rocks 2009), there is little, at this stage, to suggest that Koh Ker was a major source of sandstone for construction elsewhere in Cambodia, although positive moves are being made to compile a petrographic database 
to enable the sourcing of stone from various locations (Carò, Douglas \& Im 2009). Laterite quarries such as those identified in the vicinity of Srayang (fig. 7) are less common across the Khmer Empire - to my knowledge, these have only been identified in Siem Reap (Phann, Chrin, Chan et al. 2007), Banteay Chhmar and Koh Ker (author's field surveys) - but this could be due to a relative lack of interest on the part of researchers, and such quarries are also likely to prove numerous given the distribution of lateritic soils across the region.

Aside perhaps from particular pieces imported for particular elements such as lintels or statues, the bulk of building material for the temples is likely to have come directly from the Koh Ker area, which indicates at the very least a substantial 'local' industry in quarrying (unlike at Angkor, for instance, where sandstone and laterite were sourced from areas lying 30-40 km away at Beng Mealea, and transported to Angkor by canal (Boulbet 1979: 210; Evans 2007; Evans, Pottier, Fletcher et al. 2007). Aymonier's (1900: 410) assertion that decorated temple stone must have been sourced from afar (i.e., Angkor) where the "official ateliers" operated is not necessarily true: ateliers were almost certainly mobile to some degree, and the stone was in all likelihood decoratively carved in situ (Polkinghorne 2007). In any case, one can assume that if members of the royal court 'moved with the capital' from Angkor to Koh Ker and back again (Coedès \& Dupont 1943) that their most spccialized workmen may well have done the same, and there is in fact some evidence of this being the case at Koh Ker specifically (Polkinghorne 2007: 216, 229). In addition to the abovementioned laterite quarries, two sandstone quarries have been previously identified at Koh Ker: the one adjacent to Trapeang Khna (Parmentier 1939: 77) and another in the bed of the Stung Rongea $5.8 \mathrm{~km}$ due north of Prasat Thom (fig. 6, fig. 7) (Moriai, Matsumura \& Akama 2002; Sato 2010). Further exploration undertaken by the author as part of the present study (Evans 2009) has located a third major quarry site to the east of the temple site of Prasat Thnal Russei. ${ }^{12}$ Covering an area of approximately six hectares, according to a subsequent study by Carò and Im (2012:1457), it is by far the largest of the three major quarry sites so far identified at Koh Ker. ${ }^{13}$

Stone was acquired from the Trapeang Khna and Thnal Russei quarries using a combination of two methods: the channelling method, and splitting the protruding elements of an outcrop. The Stung Rongea site, in which the workmanship appears much more systematic and precise, or is perhaps just less degraded from weathering, is a classic pit quarry (similar to those near Angkor) achieved through the channelling method. Furthermore, it is possible that some of the permanently flooded stretches of the Stung Rongea may also be inundated pit quarries. It is quite likely that Trapeang Khna itself is an infilled and inundated pit quarry, given its irregular shape and the fact that it does not conform to the standard rectilinear model of formal Angkorian ponds. On the other hand, there is certainly no evidence at this stage to support Higham's (2001: 71) claim that the

12. When first reported (Evans 2009), this temple was given the name "Prasat Trapeang Russei" by a local informant but has appeared in subsequent reports (c.g. Sato 2010) as "Prasat Thnal Russei". The latter variation is used here to avoid confusion with the other "Prasat Trapeang Russei" located close to the centre of Koh Ker (which is also referred to as Prasat Kbal Chey, or Monument $\mathrm{K}$ and is listed with the inventory number IK 281). Note, however, that some authors continue to refer to the quarry site as Trapeang Russei (e.g. Carò \& Im 2012).

13. Interestingly, there is a partially-carved guardian lion at the site, and it is therefore to my knowledge the only sandstone quarry in Cambodia with evidence of statuary being carved in situ; the conventional understanding of statue production is that rough-cut blocks were transported from quarries to specialised sculpture workshops closer to the royal court (Martin Polkinghorne, pers. comm.). 
Rahal itself was "hewn from living rock" -.. in fact, based on extensive field investigations, this is almost certainly untrue. It should also be noted that the method of splitting outcrops and boulders that is in evidence at the Trapeang Khna and Thnal Russei quarries is an apparently common practice which remains largely unrecognized in the literature, due to an emphasis on the more 'formal' (and much more obvious) Angkorian quarries achieved through the channelling method (see however Rocks 2009). In the foothills of the Dangrek range to the north of Banteay Chhmar, for instance, it is possible to observe freestanding boulders that have been partially exploited through splitting (fig. 7), and it stands to reason that wherever boulders or outcrops of appropriate quality could be located, it would make sense to split them (if indeed that is even necessary) and dress them for architectural purposes rather than make the effort of pit-quarrying and raising stone from subsurface strata. ${ }^{14}$

Finally, in relation to stone working, there is a notion dating from Delaporte (1880:100) and Aymonier (1900: 400) that the monolithic pedestal and linga structures in temples G-K were carved 'on the spot' from natural sandstone outcrops in those exact locations. I have previously argued (Evans 2009) that this is exceedingly unlikely, particularly given the unnaturally precise symmetry of their placement to the east of Prasat Thom, although the idea continues to have some traction in the literature because of the perceived difficulties in transporting such massive pieces of stone (Jacques \& Lafond 2007: 125). There is however no evidence of stone quarrying or working around these temples, and as I will argue below, they have most likely been placed in alignment with architectural and hydraulic features to the east. ${ }^{15}$ Finally, it should not be considered so difficult, after all, to move pieces of stone of that size during the Angkorian period: one only needs to consider the enormous sandstone linga raised to a height of more than $150 \mathrm{~m}$ at Phnom Bok at Angkor, for example, or indeed the putative linga of Koh Ker itself, which was supposedly transported to Koh Ker from elsewhere, raised to a height of $36 \mathrm{~m}$ atop the Prang, and subsequently moved to another location (Cœdès 1937-66, vol. I: 60, 70). The origin and destination of this linga remains to be identified, but on the current evidence we can conclude at least that it was some distance from the Prang, and these examples indicate that it was certainly within the technical capacity of Angkorian engineers to transport megaliths and even to raise them to considerable heights.

Overall, therefore, the abundant local availability of sandstone and laterite contributes very strongly to the suitability of Koh Ker as a site for the monumental building projects associated with a 'capital', and was almost certainly a major factor in the quite particular development both of architectural forms and of massive stone sculptures at the site. The tunnels of looters at the Prang, for example, reveal that it is the only major temple mountain of the Khmer known to have a core composed entirely of masonry, instead of earth (Christophe Pottier, pers. comm.). Certainly there is no reason at all to suppose, after Parmentier, that the distance of Koh Ker from adequate quarry resources was a liability,

14. In 2002 a joint expedition of the University of Sydney and the EFEO found a very large sandstone cylinder with a volume of several cubic metres in the foothills of the mountains to the north of Angkor, approximately $30 \mathrm{~km}$ to the north of Angkor Thom. It was not found in a quarry context, and the most likely hypothesis is that it was a large freestanding boulder that had been carved down to a cylinder to allow for easy transportation by rolling, and subsequently abandoned en route.

15. Indeed, a recent excavation by a joint Japanese and Cambodian team suggests that at least one of the structures is not a natural outcrop (Shimoda, Ea, Chhun et al. 2011), and tends to confirm my argument that these megaliths were transported from elsewhere. 
except in the improbable event that it can be proven through petrographic analyses that most of the stone in Koh Ker's temples was sourced from a great distance.

\section{Systems of Water Management}

\section{Introduction}

A major focus of the research described here was re-evaluating the scale and structure of water management systems in the Koh Ker area, considering first of all, obviously, the nature of the Rahal and the numerous smaller ponds, but also with a view to assessing whether the embankment structures identified by Parmentier and Aymonier fulfilled any purpose in terms of the capture, storage and distribution of rain water and surface runoff.

\section{Excavated Ponds}

The mapping work at Koh Ker reveals 209 obviously anthropogenic ponds within the study area (the largest, of course, being the Rahal itself), or around one pond for every $0.8 \mathrm{~km}^{2}$, with a total surface area of $1.67 \mathrm{~km}^{2}$. These figures are of course for the entire study area, which may not have been all populated. In the central temple area, there are concentrations of up to 15 ponds per $\mathrm{km}^{2}$, which apparently represent densely urbanised areas south of Prasat Thom, and between Bantcay Pir Choan and Prasat Kracap; beyond the vicinity of Rahal, the areas with the highest concentration of ponds the figure reaches 4 ponds per $\mathrm{km}^{2}$, which is approximately equivalent to Angkor itself, but these concentrations are limited to the areas around Prasat Bei, Prasat Veal Kriel, and an arc between Prasat Trapeang Prei and Prasat Kok Kroel. With the exception of the Rahal, Andong Preng, and Trapeang Khna, very few of these ponds appear to be excavated deeply and (as with today) it is doubtful that they were able to hold water until the end of the dry season; however, this could be due to post-Angkorian deposition within the ponds, and excavations will be required to determine their original depth. One striking difference between the temples of Koh Ker and those of Angkor is the lack of excavated moats around temple sites: of the several dozen temples at Koh Ker, moats can only be identified at five. Compared to Angkor, furthermore, very few of Koh Ker's temples exhibit the 'classic' Angkorian spatial arrangement (Evans 2007; Pottier 1999) of a moated temple mound with a co-aligned pond to the east (or less commonly, to the north). In total, the map indicates what is perhaps at most a moderate investment in attempting to preserve water to sustain a dry-season population through the excavation of moats and ponds, which is perhaps unsurprising given that the practice is better adapted to the lowlands of Cambodia (around the Tonle Sap, and in the south-eastern provinces) with a high water table (Kummu 2009), and where Angkorian sites are typically concentrated (fig. 1).

\section{The Rahal}

Great efforts, on the other hand, were expended to contain rainfall, fluvial resources and surface runoff, as at Angkor. Much has been written about the Rahal (fig. 8), but very little detailed work on the reservoir has been completed with the exception of some test excavations by the Apsara Authority and some limited survey work by the Japanese team (Llopis 2009; Ly, Ea, Loeu et al. 2010; Sato 2010). Its alignment is of course unusual in the scheme of Angkorian hydraulic engineering, where the great reservoirs are generally oriented east-west, and the consensus among scholars is that this represents an advantageous and quite ingenious adaptation of Khmer engineering tradition to the specific topography of Koh Ker: its location in a natural valley provides a degree of natural inflow 
without the need for canalization, and only the northern and western borders of the reservoir therefore require major artificial embankments. A laterite outlet in the north bank, near the northeast corner, has been clearly identified. There has also been a broad consensus on the fact that the Rahal was designed and built under the reign of Jayavarman IV, and that it was probably donc carly in his reign, because it thereafter determined the equally unusual orientations of numerous temples in the immediate vicinity of the reservoir, including Prasat Thom itself (Aymonier 1900: 399; Bourdonneau 2011: 102; Coedès 1968 [1964]: 114; Jacques \& Lafond 2007: 110; Lunet de Lajonquière 1902: 354, 363; Parmentier 1939: 19). There are only minor variations to this conventional account. Parmentier (1939: 20) believed that a collection of laterite blocks in the midpoint of the Rahal's northern dyke represent an additional outlet, which he believed, correctly in fact, was a common feature of the great reservoirs of the Angkor period (Fletcher, Penny, Evans et al. 2008). In the published literature there is, to my knowledge, only one variation on the theory that the Rahal was designed and built at the beginning of the reign of Jayavarman IV and became the determining factor in all subsequent urban planning. It comes from Dumarçay and Royère $(2001: 4,63)$, who argue that the Rahal must predate Jayavarman IV because its lack of a fully enclosing wall is a "throwback" to an earlier tradition of Angkorian water management.

The reality, however, is that the Rahal is poorly located from an engineering point of view. It is not particularly efficient as a device for capturing water, and does not 'need' to be aligned as it is in order to ensure optimal use of the local topography. While it is true that the natural hillocks to the north-east and south-west of the Rahal lessen the need to engineer massive embankments to enclose water on those sides (note however that there are still embankments, just not very high), the small size of the Rahal and the relatively steep internal slope created by those hillocks greatly reduces the capacity of the reservoir. Essentially, instead of locating the Rahal in a wide valley, which would have ensured optimum storage capacity, the engineers at Koh Ker have placed it in a location where it encompasses the sides of two adjacent ridges. This could potentially be overcome by excavating the interior slope of the Rahal in order to create a level surface, but the only clear evidence of excavation in the interior of the Rahal (as with the baray of Angkor) is immediately next to the embankment, where earth has evidently been excavated from the interior of the Rahal in order to create the massive retaining walls. In any case, this hardly represents a clever or efficient adaptation of traditional Angkorian water engineering (i.e., the Indratataka and Yaśodaratataka baray at Angkor) to specific local topography. A much more efficient outcome could, in fact, have been achieved by building a 'classic' Angkorian baray, oriented east to west, in much the same location (fig. 9), thereby taking advantage of the broad north-south valley centered on Prasat Thom and similarly negating the need for massive embankments on the eastern and southern sides. An even better solution, even if it would have involved a measure of extra investment in building retaining walls, would have been to take advantage of that same valley in a position in the area that is now Koh Ker village.

Both of these alternative solutions, moreover, would have dramatically increased the catchment area of the Rahal. As it was built, the Rahal has a catchment of less than $4 \mathrm{~km}^{2}$, and (aside from rainwater) is fed by only by three very small streams which penetrate its eastern and southern banks, and at the height of the wet season, when the area floods during storms, by some surface runoff that washes over its relatively modest banks. Had the Rahal been placed on an east-west axis and a little to the north, it could have captured the additional flow of the streams that pass immediately to the west of Prasat Thom and 
resulted in a nearly tenfold increase in its catchment to approximately $25 \mathrm{~km}^{2}$. To go one step further, the Rahal could also have been built $5-10 \mathrm{~km}$ further north to take advantage of the Stung Rongea with a catchment in the order of $750 \mathrm{~km}^{2}$ (fig. 1).

This leaves us with three distinct possibilities: that the location of the Rahal was completely arbitrary, and/or based on imperatives that are unknowable to us; that it was a giant folly built by engineers with no clear understanding of the hydrology of the area; or that the location of the Rahal - contrary to accepted wisdom - was dictated by spatial imperatives that were a legacy of previous, intensive development of the site of Koh Ker as a religious and urban center. In the latter view, the limitations imposed by existing infrastructure, habitation sites and temple locations, in addition perhaps to traditional modes of smaller-scale water management in the area and the need to incorporate the Rahal into the symmetry of the sacred geography of Koh Ker, in fact determined the location of the Rahal, and not vice versa. This theory accords well with a range of other evidence, for example the preliminary evidence from recent archaeological excavations of the northern bank that, as mentioned above, indicate a long and complex history to the development even of the Rahal itself. The map also shows linear traces within the bed of the Rahal which suggest the possibility that it was enlarged to the south at some point in its history (fig. 8), and also that the western embankment may once have been a curvilincar structure, which as I will show below has some relevance to the so-called 'city walls' of Koh Ker to the north. North of the Rahal there is no evidence of a system of water distribution, although as Pottier (2000b) has shown, this does not necessarily preclude the existence of a simple gravity-based method of distributing water from the outlet of the Rahal through a network of bunded fields. What is more likely, however, is that the outlet of the Rahal was designed simply to provide water on demand to a second reservoir that the new map identifies directly to the north. This (as yet unnamed) reservoir, the existence of which was inferred previously (Evans 2009) and can now be confirmed by lidar elevation measurements, also takes advantage of the natural slope on its eastern flank; to the south, it is enclosed by the north wall of the Rahal; to the north and to the west, an artificial embankment completes the rectangle. No outlet for this reservoir has been found, although logically one might expect one to have existed immediately to the north of Prasat Srut (Monument A). In terms of the question of water distribution from the Rahal, there remains the issue of Parmentier's postulated additional outlet, in the centre of the north bank of the Rahal, where there is a scatter of laterite blocks. This scatter however seems unlikely to be the remains of an outlet given its location on top of the bank and the absence of a significant number of masonry blocks at the bottom of the bank on either the inside or the outside of the Rahal, where one would expect the base of an outlet to be located. There are, in any case, five major concentrations of laterite and/ or sandstone blocks at various points along the bank of the Rahal, and at least two of them (on the western bank) give a clear impression of a platform or temple rather than a device for channelling water. A GPR transect across the north bank of the Rahal by Till Sonnemann in 2009 also revealed no evidence of subsurface stratigraphic disturbances or anomalies that typically indicate infilled channels.

\section{The Dykes of Prasat Thom}

Another major revision to accepted wisdom about water management at Koh Ker comes in the form of evidence that the Rahal was merely the southernmost component of a much more extensive and elaborate network of dams and channels stretching $7 \mathrm{~km}$ to the north (fig. 10). Careful mapping and surveying of the 'urban enclosure' of Koh 
Ker, including cross-checking from lidar measurements, have revealed that it is not a coherent, single-period structure; that it is substantially curvilinear, and not rectilinear; that there is no evidence for any continuation that may have completed an 'enclosure' of any kind; and that there is a clear logic for its construction as a series of devices to dam water (fig. 8). The westernmost embankment (A) and part of the northern embankment (B) are structures evidently designed to impede and divert the flows of the various streams that converge on this area from the south. Embankments (A) and (E) extend to the area of Prasat Chen, and define the western and eastern sides of a series of dykes designed to manage the flow of water from large flows coming from the south and southwest. Embankments (A) and (B), which achieve heights of up to $2-2.5 \mathrm{~m}$, are in relatively poor condition and although they are occasionally reinforced with laterite rubble they are not as massive as the northern and western walls of the Rahal. Furthermore, although embankments (A) and (B) have traditionally been considered part of the "unitary conception" of Koh Ker's walls that included embankment $(C)$, in fact embankments $(A)$ and (B) were likely built during a different program of public works than embankment (C), which is one to two metres higher, much more massive, and is heavily reinforced by laterite rubble on its northern face. It is possible that $(C)$ is a later improvement of an original extension of (B), since there is some evidence of a distributor canal (D) extending northward from what may have been the original, coherent northern dyke. Embankment (E) is also inconsistent along its length, and seems also to reflect multiple periods of planning and construction. At its southernmost end, south of Andong Preng, it strongly resembles embankment (A) as a quite massive embankment enclosing a stepped series of rectangular reservoirs (F); however, north of Andong Preng it takes on a markedly different form: here it is low, averaging $1.5 \mathrm{~m}$ in height, and has evidence of canalization on the eastern side. This embankment may have been constructed contemporaneously with the Rahal and/or Prasats Dang Tong $N$ and $S$, in order to better contain the water trapped by embankments (A) and (B) and perhaps channel further runoff or overflow to the north away from those temples and from Prasat Thom.

\section{A Northern Dam}

By far the most substantial of all of Koh Ker's water control systems is earthen embankment $(\mathrm{G})$, first identified by Aymonier and generally interpreted as a "royal road", which extends $2.4 \mathrm{~km}$ due north from the central temple zone before changing course and continuing $2 \mathrm{~km}$ to the northwest, ending in a complex series of banks where it meets the (modern) flow of the Stung Rongea (fig. 10). In its first stage, proceeding due north from Koh Ker, it is approximately $60-70 \mathrm{~m}$ wide, is quite heavily reinforced with laterite rubble on its western flank, and achieves heights of up to $4 \mathrm{~m}$ above the surrounding landscape. ${ }^{16}$ In terms of its scale and morphology, it bears much resemblance to, and is probably contemporary with, embankment (C) from which it departs. As it departs northward from embankment $(C)$, embankment $(G)$ actually formalises an irregular, low-lying natural ridge extending north from Koh Ker, but is nonetheless an almost entirely artificial construction made from mounded earth, except for a small 200 $m$ section within the village of Thmei where it takes advantage of a sandstone outcrop. Five hundred metres north of Thmei village, where embankment $(G)$ changes course to the northwest, there is also a marked change in morphology, as it departs its previous

16. In spite of localised topographic variation, the lidar data indicate a reasonably consistent absolute height for the top of this section of the embankment of between $69.5 \mathrm{~m}$ and $71 \mathrm{~m}$ AMSL. 
course along a natural ridgeline: for approximately $1 \mathrm{~km}$ northwest of here (location $\mathrm{H})$, the embankment is at least $100 \mathrm{~m}$ in width and rises to heights of more than $10 \mathrm{~m}$ above the surrounding landscape, ${ }^{17}$ and is again reinforced on the western flank by laterite rubble, before once again diminishing in size as it joins a naturally elevated area, performing a series of turns and switchbacks around the Stung Rongea and eventually joining a low-lying natural promontory that extends southeast from Prasat Ta Mean and the Beng Mealea to Wat Phu Road.

In fact, a primary function of the entire assemblage of embankment $(\mathrm{G})$ is absolutely and unambiguously that of a dam. Angkorian roads with no associated water function typically consist of elevated earthen embankments that are raised 1-2 $\mathrm{m}$ above the lay of the land. This feature, on the other hand, strictly maintains an absolute height of between $69 \mathrm{~m}$ and $72 \mathrm{~m}$ for its entire $7 \mathrm{~km}$ length, exactly as one would expect from a dam, even though the lay of the land surrounding it varies widely (from between $10 \mathrm{~m}$ to exactly level). It is obviously designed to capture the flows proceeding northward from Koh Ker and also, more importantly, the much more substantial eastward flow of the Stung Rongea itself. The newly acquired lidar data, as well as a comprehensive pedestrian survey of the morphology of this massive artificial ridge, clearly shows that the original course of the Stung Rongea, and the streams from Koh Ker which join it, was to the east through low-lying floodplains immediately to the west of Prasal Thnal Russei. The largest section of embankment $(\mathrm{G})$, to the north of Thmei village at location $(\mathrm{H})$, was specifically engineered to withstand the force of that flow; the remainder of embankment $(G)$ would have effectively contained that water resource and flooded much of the broad, low-lying valley that extends north from the centre of Koh Ker and then arcs westward from location (H) along the basin of the Stung Rongea (fig. 10). In this view, the present course of the Stung Rongea from location (I) to location $(\mathrm{J})$ is not a purely natural phenomenon, but is predominantly a legacy of the breaching of the dam at location $(\mathrm{K})$ and the northward escape of water to join what may originally have been, at most, a very meagre stream flowing eastward from near Prasat Ta Mean.

The existence of a large body of water in this location not only helps to explain the relative absence of archaeological features in the area, but may also clarify the reason for the existence of the main east-west embankment immediately to the north of Koh Ker (locations (B) and (C) in fig. 8 and fig. 10), which as I have already argued is almost certainly not the remains of an "enclosure wall". The lidar elevation data show that embankments (B) and (C) also maintain an absolute height of $69 \mathrm{~m}$ and $72 \mathrm{~m}$, which is perfectly consistent with an explanation for them as the southern wall of the great dam to the north of Koh Ker. The junction of embankments (A) and (B) meets at a natural ridge and effectively closes off the northern half Koh Ker's hydraulic system from the southern half; thus, in the wet season embankments (B) and (C) would have protected the central temple area from the rising waters of the great dam to the north, while at the same time retaining a moderate amount of water during the dry season on its southern side, in the immediate area of Prasat Thom.

\section{Spillway of the Northern Dam}

In addition to the hydraulic logic of its position, other evidence indicates that embankment $(G)$ is a dam and is quite consistent with Angkorian techniques of water manage-

17. Nonetheless, the absolute height of the top of the embankment remains essentially consistent at approximately 70-71 m AMSL. 
ment in the late 9th to early 10 th centuries, which are increasingly well understood due to ongoing work at Angkor by the Greater Angkor Project (Fletcher, Penny, Evans et al. 2008; Fletcher, Pottier, Evans et al. 2008; Kummu 2009). In the modern village of Thmei, a finely constructed masonry spillway, $1816.5 \mathrm{~m}$ in width from east to west and built from interlocking blocks of laterite, extends north-south for $190 \mathrm{~m}$ along the castern (or 'exterior') flank of the dyke, with a gradient designed to facilitate the flow of excess water (above a level of approximately $69 \mathrm{~m} \mathrm{AMSL}$ ) over the dyke, out of the dam and into a collector channel to the east (fig. 11) without eroding or compromising the integrity of the earthen dam. It is analogous in many respects to the spillway of the Bam Penh Reach diversion dam at Angkor, which also likely dates from the late 9th to early 10 th centuries due to its method of construction and its logical association with the East Baray (Fletcher, Penny, Evans et al. 2008: 663-664), although the spillway at Koh Ker takes advantage of a natural sandstone outcrop for its foundation, and the earthen embankment that it would have buttressed has been substantially eroded (rather than buried, in the case of Bam Penh Reach). Indeed, the spillway of this northern dam at Koh Ker has itself been completely destroyed in sections, with large laterite blocks strewn over half a hectare on the 'outside' slope of the dam wall, and some blocks lying as far as $200 \mathrm{~m}$ away from the actual spillway. Intriguingly, although the area experiences a measure of surface runoff during the rains of the wet season, this is almost certainly not sufficient to account for the wide distribution of blocks beyond the breach in the spillway, which may indicate a catastrophic failure of the device at a time when the northern dam was full - that is to say, at the time it was still functioning during the classical Angkorian period.

\section{Outlet of the Northern Dam}

The other feature of the vast northern dam that is analogous to contemporary hydraulic works at Angkor is a masonry outlet channel (see (K) in fig. 10) near the northern extremity of embankment $(\mathrm{G})$. Like the site of Krol Romeas, which functions as an outlet to the East Baray at Angkor (Fletcher, Penny, Evans et al. 2008: 664-665; Pottier 1999), it consists of two parallel walls of laterite masonry, $5 \mathrm{~m}$ high and $30 \mathrm{~m}$ apart, each buttressed with earth on the exterior. Unlike Krol Romeas, however, which is $100 \mathrm{~m}$ in length, the outlet of the northern dam at Koh Ker extends for $240 \mathrm{~m}$, and there is no evidence at this stage that its interior space was paved with laterite masonry, and no specific indication of where the water barrier or sluice was located; however, the Koh Ker outlet lies in the middle of a heavily vegetated, uncleared minefield and detailed investigations of its structure remain difficult and dangerous for the time being. In addition, and again unlike at Krol Romeas, the Koh Ker outlet has a $220 \mathrm{~m}$ (southward) extension to one of its walls along the interior slope of the dam, no doubt intended to protect the earthen embankment there from erosion and destruction when water was being discharged through the outlet.

18. Local people commonly interpret this structure as a causeway, platform or bridge that has subsided unevenly to the point where its surface apparently slopes down the western side of the embankment. This is not a plausible explanation. It is certainly not a bridge, because there is no evidence for any passages for water to flow underneath the structure, even where the structure is intact and almost completcly exposed above the surface. Nor can it be a causeway or horizontal platform: many of the blocks are not actually rectilinear, but have an irregular or rhomboid shape, and were clearly carved and set in place in order to create a sloping masonry structure down the east side of the embankment (fig. 11). 


\section{Closure and Breaching of the Northern Dam}

To the west of the outlet (at location (K) in fig. 10), another very large embankment, reinforced on the interior slope of the dam by laterite rubble, extends to meet a prominent natural ridge that forms the final connection to the natural promontory extending southeast from Prasat Ta Mean, thus completing the closure of the dam. Where this dam has been breached by the flow of (what would thereby become) the Stung Rongea, sandstone and laterite blocks and rubble are strewn across the river bed, and are no doubt the remains of the embankment that used to block the flow of water in this area.

One hundred and fifty metres to the south of the breach, there is also evidence of an additional, smaller water barrier, which at one stage may have blocked the flow of the Stung Rongea (fig. 11). A linear series of postholes, regularly spaced and all approximately $2 \mathrm{~m}$ apart, traverse the $40 \mathrm{~m}$ width of the sandstone stream bed at an angle of 280 degrees. These postholes are all between $15-19 \mathrm{~cm}$ in diameter, have a mean depth of $16 \mathrm{~cm}$, and are easily distinguishable from the many natural holes in the sandstone of the area by the uniformity of the structure and the evidence of vertical chisel marks along their sides. In at least three places within this linear array of postholes, natural fissures within the sandstone take the place of artificial holes within the sequence. Where the line of postholes meets the natural sandstone of the eastern (right) bank of the Stung Rongea, a large groove has been cut into the sandstone bank, probably designed for a large wooden pole to buttress the connection between the dam and the bank (note however that it is $2 \mathrm{~m}$ upstream away from the alignment of the postholes, and that there is no analogous feature visible on the western [left] bank). In general, the interpretation of this particular site as a dam is problematic, because there are alternative explanations: that it was a wooden bridge, for example, or that it was a mechanism for supporting a large net traversing the stream for fishing in the wet season. The latter, however, is to my knowledge unknown either in contemporary Cambodia or from Angkorian bas-reliefs, and one would obviously expect a bridge to require two parallel lines of postholes, not just one. From a chronological point of view, if we follow the hypothesis that the broad flow of the Stung Rongea in this area is an outcome of the breaching of the principal northern dam of Koh Ker, that is to say embankment $(\mathrm{G})$, it could be argued that these postholes represent the remains of a more modest attempt to dam the flow of the Stung Rongea in the later history of Koh Ker. On the other hand, they may also represent an earlier stage of construction of the principal dam, in which postholes were driven at regular intervals down through the surface soil to the bedrock to provide a wooden interior structure underneath the earthen superstructure of a dam, as with the south wall of the West Baray (Christophe Pottier, pers. comm.). There are traces of banks and masonry rubble on the landscape around both sides of the posthole feature which tend to support this explanation; one theory might be that the original outlet for the northern dam at Koh Ker was located here, and was later replaced by the far more durable and massive construction that I have described above.

\section{Summary}

What becomes abundantly clear from the new research is that vast efforts were, indeed, expended on the management of water resources in the Koh Ker area: in sections, the scale of the northern dam approaches the dimensions of the greatest water control device at Angkor, the West Baray (Fletcher, Penny, Evans et al. 2008: 662), and would have flooded between 4 and $5 \mathrm{~km}^{2}$ of the landscape with water up to $7 \mathrm{~m}$ deep in places, providing an excellent dry season water resource for rice growing, varied cultivation, domestic use, grazing and fishing. Returning once again to Parmentier's irrigation hypothesis, could the 
dam have been used for rice irrigation, and substantially increased the population carrying capacity of the landscape? Here there is certainly more agricultural potential than with the Rahal. To perform some extremely rough calculations, with numbers again generously in favour of Parmentier's hypothesis: if the average height of water at the dam was $5 \mathrm{~m}$, receding over $5 \mathrm{~km}^{2}$ across an even slope to a height of zero, the northern dam may have contained enough water to feed perhaps an additional 9000 people. In addition to the figures from the Rahal, this does indeed begin to look like a very significant potential contribution to the agricultural productivity of the land within the study area. As with the Rahal, however (and indeed, as with Angkor itself), there is no conclusive evidence that this potential was systematically realized. Aside from the main outlet in the north there are channels, particularly in the area of Prasat Boeng Veng, which may indicate off-takes from the dam; however, all of these outlets are notable for having very little agricultural potential downstream, with essentially no evidence for pre-modern field systems, or a further cascading series of dams, or indeed any structures that would prevent the water simply evacuating into the Stung Sen. On the current evidence, then, it seems likely that the water control devices were not used for downstream irrigation, but simply to ensure a water supply for the population of Koh Ker; if they made any contribution to rice production at all, it would be through the use of the receding floodwaters of the dam for aquaculture and flood retreat rice agriculture, ${ }^{19}$ but again, there are none of typical signs of that system either (e.g. a cascading series of minor U-shaped dykes upstream of the major dam, as one commonly sees at Angkor).

\section{Patterns of Urbanisation}

\section{The Issue of 'Urban Enclosures'}

Another historical issue that is resolved from the research undertaken so far is that the dykes north of Prasat Thom almost certainly do not represent the remains of a formal "enclosure" as traditionally understood. As mentioned above, Parmentier himself offered a somewhat confusing account of the issue: while he certainly believed that the dykes enclosed an urban area of some kind, he nonetheless conceded, on the basis of the broad distribution of temples, that the limits of the city were difficult to define (1939: 16, 106). Subsequent interpretations of the urban space of Koh Ker have tended to echo Parmentier's conflicting ideas, in the absence of careful consideration of what is actually meant or defined by the words 'city' or 'site' in relation to Koh Ker. Briggs (1999 [1951]: 117), for example, repeats the $1200 \times 1200 \mathrm{~m}$ walled city idea. Higham (2001: 71), even though he notes (after Parmentier) that there is a distribution of temples covering $35 \mathrm{~km}^{2}$, nonetheless agrees that there is a $1200 \times 1200 \mathrm{~m}$ walled urban area that "followed in the tradition of ... Hariharālaya".

Jacques (2007: 110), who also notes the broad distribution of temples across $35 \mathrm{~km}^{2}$, is perhaps the only scholar who has written on Koh Ker to cast doubt on the very existence of an "enclosure" at the site. For this reason, he believes that the urban structure of Koh Ker is highly atypical, considering that in his view (as with Higham) the traditional layout of a Khmer city, in the tenth century, consisted of a square, earthen city enclosure with a royal temple at its centre, with that ensemble neatly defining the formal urban space. In this context, it is worthwhile reconsidering the entire notion of formally enclosed urban spaces in Khmer history in order to assess whether or not Koh Ker was, indeed, so unusual.

19. I am grateful to Terry Lustig for suggesting this possibility. 
Recent research (Pottier 1999; 2000a) disputes the existence of the pre-Angkorian enclos ure of Banteay Chhoeu in Siem Reap; demonstrates that 8th to 9th century occupation at Hariharālaya extended well beyond the temple enclosures; and proves that the 9 th century "walls of Yaśodharapura" were not city walls but actually dykes to control water that were built in the 11 th century. It would seem, therefore, that most Khmer cities since the pre-Angkorian period might be defined as "open cities" characterized by a "remarkable rural-urban continuum" (Pottier 2006: 66) and fundamentally unconstrained by enclosures or formal urban planning. In fact there is, to my knowledge, no compelling evidence in the published literature that formally bounded urban areas were constructed at all in northwest Cambodia until the 12th to 13 th centuries. Furthermore, even then 'bounded cities' such as the Angkor Thom of Jayavarman VII (Gaucher 2003) show evidence of a contemporary low-density settlement pattern stretching far beyond their walls (Evans 2007; Pottier 1999), and new data from the 2012 lidar acquisition shows that the formallyplanned grid of city streets previously thought to be the defining urban characteristic of Angkor Thom is not simply an intra-mural phenomenon. Thus, Koh Ker is not at all located within a 'tradition' of enclosed cities, and the absence of an enclosure wall can be considered completely unremarkable for that period of Khmer history.

\section{Settlement Pattern and Modes of Habitation}

As mentioned above, however, the apparent absence at Koh Ker of the 'classic' lowland settlement pattern - moated temple mounds with a pond to the east, surrounded by occupation mounds and additional ponds - is interesting at Koh Ker. There are likely two reasons for this: firstly, that the lowland pattern is well-adapted to areas with a high water table (Acker 2006; Kummu 2009) but would have provided little benefit at Koh Ker; and secondly, the fact that the undulating terrain of Koh Ker, with its rolling hills and outcrops of stone, makes anthropogenic mounds relatively difficult to discern using aerial archaeology. The key indicator of occupation at Angkor is surface scatters of ceramics, which again are relatively scarce at Koh Ker compared to Angkor; this is probably because very few areas of Koh Ker are currently inhabited and cultivated, and there is minimal disturbance of the subsurface cultural layers. In spite of this, some mound complexes with surface ceramics can be identified. Although it may in fact consist mostly of a low-lying natural ridge, the modern day, elevated village of Koh Ker that stretches north of Prasat Thom to embankment $(\mathrm{C})$ is one example, and ceramics are particularly abundant immediately to the north of Prasat Thom and on embankment (C) itself (fig. 8). This suggests that both mounds and embankments were favoured locations for occupation, as at Angkor (Fletcher 2000-2001; Fletcher, Barbetti, Evans et al. 2003). Although some high-quality stoneware is evident, the vast majority of the sherds visible on the surface are earthenware, which may tend to suggest that these mounds and embankments were residential spaces rather than areas devoted exclusively to royal or religious activity. In fact, this distribution continues south along the west wall of the Rahal to Prasat Chen, with a particularly dense coverage of sherds in the area around, and just to the west of, Andong Preng (cf. discussion below relating to the location of the royal palace). Aside from roof tiles, which are frequently associated with temples, there are dense concentrations of non-architectural ceramics at Prasat Boh Lohon and Prasat Chen that indicate intensive occupation of those sites.

Probably, on the current evidence, we are forced to rely on the gross distribution of temples as a rough indication of population distribution, considering that Angkorian religious foundations, from the largest to the smallest, generally relied upon a network of 
surrounding residential areas for their establishment and maintenance (Evans 2007; Lustig 2001, 2009). However, no research has provided clear evidence of the spatial distribution or organisation of those 'supporting' settlements at Koh Ker or anywhere else. In spite of assertions by Aymonier (1900: 409) and others that monumental engineering indicates the immediate presence of a large population, this remains to be proven at Koh Ker. In fact, the Khmer-language sections of the inscriptions at Koh Ker are famously preoccupied with the appropriation of temple workers from elsewhere (Cœedès 1937-66, vol. I: 47-71: Jacques \& Lafond 2007: 125; Lustig, Evans \& Richards 2007). Although Jacques takes this as evidence that labour was being appropriated from across the Khmer Empire, it is entirely possible that many of the places mentioned in the Koh Ker inscriptions refer to localities lying within the study area, or otherwise near to Koh Ker itself. Efforts to compile a toponymic atlas from Khmer epigraphy may ultimately help to clarify this issue; in the meantime, both Kunthea Chhom (2011: 19) and Eileen Lustig (pers. comm.) have noted that the place names mentioned in the Khmer-language inscriptions of Koh Ker are predominantly "villages" rather than "provinces" (the former outnumber the latter by an order of magnitude, in fact), which could reasonably be interpreted to mean that the origin of the work force was from familiar, well-established communities in the immediate area, rather than from distant territories.

On the other hand, it is worth noting incidentally that although many other inscriptions of the first half of the tenth century address issues related to land tenure, including Jayavarman IV-era inscriptions elsewhere in Cambodia, none do at Koh Ker. The first inscription to do so here, in fact, is the K. 674 from Prasat Dan which dates from 966 $\mathrm{AD}$, some decades at least after the conventional date for the establishment of the site (Cœedès 1937-66, vol. I: 47-71; 1964: 89-90; Higham 2001; Lustig 2009). Moreover, discussions of land tenure issues in Khmer epigraphy frequently mention land being delineated with boundary posts (Coedès 1937-66), and these sandstone artifacts can still be identified in many settlements across Cambodia. In Angkor, they are almost exclusively found in rural areas, and the most significant distribution is north of the West Baray in an area densely populated with 'village temples' and given over to agricultural land during the Angkor period (Evans 2007; author's field investigations; Christophe Pottier, pers. comm.). Sandstone boundary posts are also well represented in the surface archaeology of Koh Ker (fig. 8), but seem invariably to mark significant locations in the structure of the hydraulic network, rather than fulfilling an obviously cadastral function in relation to agricultural or residential space. In light of the relative absence of evidence for occupation, the preoccupation of the inscriptions with the appropriation of labour and their neglect of land-related issues, it may be useful to consider the possibility that Koh Ker was to some extent 'land rich but people poor', that is to say, that its existence (as a capital at least) may have relied to a large extent on the capacity of its ruler to enlist a work force from distant settlement sites in order to build and maintain the royal court. This could have been an essentially transient dry-season labour force that returned home to cultivate rice during the wet season, or a sedentary population based permanently at Koh Ker. As noted above, there are very few temples within the study area that conform to the 'classic' lowland model of Angkorian occupation sites (Evans 2007), and these are mostly located a considerable distance (at least $4 \mathrm{~km}$ ) from the centre of Koh Ker.

\section{Ceramics and the Dating of Occupation}

Although the nature of Koh Ker's settlement structure and demography therefore remains somewhat ambiguous, the preliminary analysis of ceramic sherds reveals evidence of a 
very lengthy history of occupation (fig. 12). As noted by Llopis (2009), potentially (but by no means certainly) pre-Angkorian earthenwares can be found in abundance in certain locations. Surface collections by the Hungarian team at Prasat Boh Lohong, for example, include fragments bearing strong stylistic similarities to earthenwares from layers at the pre-Angkorian temple of Prei Khmeng at Angkor; these wares are commonly found in contexts at Angkor dating (approximately) from the 1st to 8th centuries AD, but are rare thereafter (Christophe Pottier, pers. comm.). ${ }^{20}$ Presently the earliest dates for ceramics at Koh Ker come from thermoluminescence dating on material from Prasat Kracap (Sipos, Belényesy \& Bozsó 2011); although most of the dates returned fell within the range of the 10th to 13 th centuries, the authors present two samples with approximate ages of 1700 and 4000 years, and are confident of the accuracy of their findings. Additional field surveys, as well as excavations undertaken by the Apsara Authority and the Hungarian and Japanese teams (Belényesy 2011; Ea 2011; Ly, Ea, Loeu et al. 2010; Shimoda, Ea, Chhun et al. 2011; Shimoda, Uchida, Chhun et al. 2011), have resulted in finds of greenglazed "Kulen" wares and typical brown-glazed stonewares (notably along the west bank of the Rahal, but also near Prasat Trapeang Prei, at Prasat Boh Lohong, Andong Preng, and Prasat Kracap) indicating intensive occupation of the site into at least the late 10th or early 11 th century, and probably well into the 12th to 13 th centuries (see Hendrickson 2008: 55), although given corroborating inscriptional and architectural evidence for a sustained later occupation of Koh Ker into at least the 12th to 13th centuries, this outcome is not surprising.

In addition to these locally produced wares, numerous sherds of imported wares have been analysed and dated in recent years (Li 2011; Shimoda, Uchida, Chhun et al. 2011). In respect of a terminal date for occupation, some of the most interesting finds have included a full suite of Chinese ceramics spanning the 11 th to 19 th centuries at Prasat Boh Lohong; Chinese covered boxes from the 11 th to 13 th centuries at Prasat Kracap; Ming Dynasty (1368-1644) blue and white porcelain from the Jingdezhen kilns in Jiangxi around embankment $(\mathrm{F}) ;^{21}$ and Chinese blue and white ware from the late 19th to early 20 th at Andong Preng. 22 Much work remains to be done on the ceramics of Koh Ker, and ceramics from well-dated and stratified contexts will be essential in reaching any firm conclusions; nonetheless, it is remarkable that essentially every excavation or surface survey of the area reveals significant amounts of ceramic material dating from beyond the conventional dating of Koh Ker as the capital of the Khmer Empire. On the current evidence, indications are that the site has been occupied, perhaps even continuously, for at least one thousand years.

In fact, the site was potentially occupied for even longer than this, considering that (in spite of its generally 'upland' location) there are seasonally inundated lowlands at Koh Ker that would provide an amenable environment for the development of pre-

20. Unfortunately, therefore, we cannot be absolutely certain that these are in fact ceramics from the pre-Angkorian period. In spite of the number of reports that contain references to the existence of pre-Angkorian ceramics at Koh Ker, it is regrettable that so little scientific analysis of these sherds has been undertaken or published.

21. Information from Lin Baoping and John Miksic. Miksic suggests in fact that the Ming Dynasty sherds date from Wan Li period, in the late 16th or early 17 th centuries.

22. John Miksic identifies several sherds from the site of Andong Preng as coming from what are known as "double happiness bowls" after the Chinese characters that appear on them; they are commonly found in excavations of colonial sites in Singapore. These are the same sherds referred to by the Japanese team (Shimoda, Uchida. (hhun et al. 2011), although they provide no date. 
historic mounded sites that are found in abundance in northwest Cambodia. These are generally dated to approximately $500 \mathrm{BC}$ to $500 \mathrm{AD}$ (Evans 2007; Malleret 1959; Moore 2000; Richards 2007), although human occupation of mounded sites has been a feature of Angkor for a period of time approaching 4000 years (Pottier 2007; Pottier \& Bolle 2009; Pottier, Bolle, Llopis et al. 2005). Therc prchistoric sites (often incorrectly called 'circular sites' or 'moated sites' even though they are often not circular and usually not moated) are characterised by a 'radial' field system which extends from an irregular central mound, in which concentric circles of field walls surrounding the mound are intersected and divided by field walls radiating directly outward and away from the mound itself (Evans 2007: 185). This quite characteristic spatial patterning has been identified in two locations within the study area (one just to the north of Prasat Dan, and another around Prasat Trangol), and warrants further attention, particularly in light of the very early dates returned by TL dating of ceramics (Sipos, Belényesy \& Bozsó 2011). ${ }^{23}$

\section{The Royal Palace of Koh Ker}

In addition to general issues of settlement pattern and population distribution, there remains the issue of the location of the royal palace of Koh Ker, which has not been clearly identified but has been variously proposed as being Andong Preng (Aymonier 1900: 409), or the buildings $\sim 200 \mathrm{~m}$ to the east of the east gopura of Prasat Thom variously named 'Prasat Srut' by Apsara (Ly, Ea, Loue et al. 2010) or 'Monument A' by Lunet de Lajonquière (Parmentier 1939: 20-21), ${ }^{24}$ or the area 'enclosed' by the dykes of Koh Ker (Jacques \& Lafond 2007: 110). In 1933 Parmentier (1939: 17) carried out excavations near Andong Preng in order to evaluate Aymonier's hypothesis, which was based on the availability of clear water within the basin of Andong Preng and the existence of a series of obvious laterite foundations (presumably for galleries of wooden walls, from their configuration) immediately to the east, which were recently documented in some detail by the Japanese-Khmer team (Shimoda, Uchida, Chhun et al. 2011). Parmentier found nothing in particular to confirm Aymonier's theory, and the question, for now, remains open. It seems however that the most likely position for the royal palace would indeed be the area around Andong Preng. Field investigations and aerial prospection of the area have revealed traces of a laterite foundation for an enclosure wall measuring approximately $300 \times 220 \mathrm{~m}$, which abuts the bank of the Rahal on its eastern side, in addition to the numerous laterite foundations for galleries that exist within that enclosure. There is no evidence of a religious structure within this enclosure, yet stoneware roof tiles are ubiquitous, which indicates the former existence of an impressive wooden structure unrelated to any particular temple. Staff at the demining camp formerly located at the site collected some very fine examples of (non-roof tile) glazed Angkorian stoneware from the ground within this enclosure. Evidence from Hariharālaya and the 'Eastern

23. Field investigations at one of the sites in 2009 by the author with the assistance of Arianna Traviglia and Stephen White did not reveal any clear surface evidence of prehistoric occupation, but this is not uncommon, even for sites that are unambiguously "pre-historic", and is therefore an inconclusive result. The second of the sites was inaccessible due to an uncertain situation in relation to land mines. It also seems rather difficult to take at face value the very early TL date of -4000 BP that has been reported. in spite of the authors" confidence in the validity of the date. The 2012 lidar remote sensing acquisition provides no particular insight into the issue, which is unlikely to be resolved conclusively without excavation.

24. Parmentier was in fact reporting the interpretation of the local people about the function of this building, but his text suggests that he himself was sceptical. 
city' of Rajendravarman indicates that other royal palaces of the 9th to 10th centuries were also rectangular structures located immediately to the south-southeast of the King's principal state temple (Pottier 1999), even if the royal palace of Yaśovarman I remains to be unambiguously defined. It is likely that systematic, large-scale archaeological excavations at Andong Preng would uncover evidence of a royal palace in the location, and provide valuable new information on the apparent rise and fall of Koh Ker as the 'capital' of the Khmer Empire.

\section{Road Connectivity}

\section{Connections to the Angkorian Highway Network}

Until recently (Hendrickson 2007; Phann, Chrin, Chan et al. 2007) there was a measure of uncertainty about the true course of many of the great highways linking the farther reaches of the Khmer Empire to Angkor, and numerous maps and texts have been published with the erroneous depiction of a road proceeding from Angkor and Beng Mealea directly to Koh Ker (Bruguier 2000; Coe 2003: 151; Ishizawa \& Hitoshi 1999: 198; Jacques \& Lafond 2007: 133). In fact, Hendrickson's (2007) detailed mapping shows that the highway in question (which connects Beng Mealea to Wat Phu) passes some $6 \mathrm{~km}$ to the north of Prasat Thom.

However, although this report has suggested that numerous linear embankments in the Koh Ker area that have previously been identified as roads or 'enclosure walls' be re-interpreted as dykes for the control of water, it is important to point out that this does not preclude their use as important arteries of transportation and communication. It is well-recognised that the earthen embankments and hydraulic structures built by the Khmer in pre-modern times served multiple functions (Bruguier 2000; Evans 2007: 27,104; Groslier 1979), and even if the primary function of large-scale engineering works at Koh Ker can now be identified as the control of water, there is no doubt that they would also have facilitated interaction between widely dispersed communities in the study area, particularly along the north-south axis stretching from the Rahal to the Beng Mealea to Wat Phu Road.

The map presented here strongly suggests that the dam extending northward from Koh Ker was a multi-functional structure that included a road on top of the embankment; Koh Ker would, therefore, have effectively been connected to the highway network by an elevated, all-weather route. Jacques (2007) argues that this connection attests to the enduring importance of Koh Ker for several centuries after it had ceased to become a capital, but on the current evidence this is difficult to assess. Although the bulk of its final engineering was probably achieved during the twelfth century (Hendrickson 2007), the highway network may have existed in some form or another for several centuries previously; complicated chronological issues therefore preclude any definitive conclusion. Once again, a program of excavation at the junction of the Beng Mealea to Wat Phu highway, and the embankment that connects it to Koh Ker, would likely provide some insight into the issue.

\section{Architecture and Inscriptions}

The great majority of previous studies of Koh Ker have focused on architecture, art history and inscriptions, and very little archaeological analysis has been completed outside of these domains. The main purpose of this study is to begin to redress that imbalance, and 
in light of the new evidence presented above, it is worthwhile considering, briefly, some of the implications for our understanding of the architecture and the epigraphy of the site.

\section{A Mebon in the Rahal?}

Considering the extensive programs of exploration and survey at Koh Ker in recent years, which have documented numerous additional archaeological sites at Koh Ker, including some temples (Evans 2009; Mizoguchi \& Nakagawa 2011), it seems unlikely that any major additions will be made to the inventory of known temples within the study area from this point forward. On one of the more recent maps of Koh Ker (Phann, Chrin, Chan et al. 2007; see fig. 4), which is otherwise based almost entirely on the work of Parmentier, a feature has been added to the centre of the Rahal that seems to indicate the existence of an island-temple or mebon. However, intensive investigations on the ground have failed to uncover any evidence of the existence of a structure here, or even occupation. There are no architectural remains or ceramics, and a GPR survey revealed no obvious anomalies suggesting the presence of buried structures or major disturbances to the natural soil. In all likelihood, therefore, there was no mebon in the Rahal of Koh Ker. Although there is indeed an area of higher ground in the centre of the reservoir, this appears to be nothing more than a low-lying promontory of the hillock that forms the eastern flank of the Rahal, or perhaps colluvium from that higher ground. Another error in that map - and indeed, in all previous maps of the site of Koh Ker - is the placement of the massive artificial mound to the west of the Prang (known as Phnom Damrei Saw) directly on the axis of the Prang and Prasat Thom, and at some distance from the enclosure wall of the Prang, whereas in fact aerial surveys show that this mound is displaced from the axis by several metres to the north, and that its (flattened) eastern flank directly abuts the outer enclosure of the Prang/Prasat Thom complex. ${ }^{25}$

\section{The Orientation of Monuments and Embankments}

Much has been made of the unusual orientation of the monuments at Koh Ker. In fact, most of the monuments here are oriented quite conventionally, either towards the east or with a measure of deviation to the northeast (as with a great many sites at Angkor, for example in the Neam Rup area but also Banteay Kdei, the Srah Srang, Prasat Trapeang Ropou, the walls of Angkor Thom, the East Baray, Banteay Samre, and further afield at Preah Khan of Kompong Svay, Banteay Chhmar, Sambor Prei Kuk...). A small number of temples at Koh Ker face west; although this is indeed relatively rare, it is by no means unknown (Angkor Wat being only the most famous example). What remains as highly unusual and quite specific to the Koh Ker area is the array of temples oriented towards the southwest. Parmentier's (1939: 16) suggestion that those located to the east of the Rahal are so oriented because of the existence of the reservoir was a satisfactory explanation, as far as it went; however, it could not explain the orientation of the great linga shrines to the north (IK 280, 279, 297.02, 278), and to account for this Parmentier posited the

25. Boisselier noted the peculiar shape of this mound as early as 1952 (describing it as essentially 'triangular'), as well as its axial displacement (EFEO Archives, Paris: Carton 1, Dossier V: Boisselier, Jean. Activités scientifiques. Rapport sur la mission exécutée dans le groupe de Koh Ker et les groupes

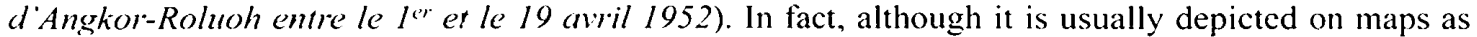
being circular at the base, the new lidar elevation data show that it is considerably flattened on both the eastern and northern sides, and that Boisselier`s characterization is quite accurate. 
existence of a hypothetical road extending northwards from the east wall of the Rahal, following its axis. However, the solid identification of a second reservoir immediately to the north of the Rahal (fig. 8) effectively resolves this issue: every major temple in Koh Ker facing southwest, including Prasat Neang Khmau, is thus oriented towards an adjacent, formalised, rectangular body of water. ${ }^{26}$

The existence of this newly identified reservoir also imparts a certain spatial logic to the arrangement of all of the features to the east of Prasat Thom: at one stage an earthen causeway, now partially eroded, connected the eastern gopura of Prasat Thom to the large earthen platform upon which Prasat Srut was built, which itself formed a kind of 'landing' on the western edge of the reservoir perhaps analogous in some ways to the (original) landing of the Srah Srang at Angkor, or the large earthen platform on the middle of the west bank of the East Baray, all of which were built within the same half century or so. It is possible to see the remains of a small feature - possibly a causeway, or possibly a double-banked canal ${ }^{27}$ - protruding east into the reservoir. The cruciform structure to the west of one of the linga shrines (Prasat G, IK 278), has previously been implied to be a gopura associated with some kind of enclosing wall (Phann, Chrin, Chan et al. 2007), but in fact, from architectural and remote sensing studies, it becomes clear that it is also a landing designed to facilitate access up the wall of the reservoir from water level to the level of the shrinc. ${ }^{28}$ The now map shows clearly that the four linga shrines and Prasat Andong Kuk stand in near-perfect symmetry with the eastern edge of the reservoir, and perpendicular to the axis of Prasat Thom, clearly forming a spatially coherent ensemble of temples and reservoirs. ${ }^{29}$

\section{The Linga Shrines}

Principally because they all lack a roof, these linga shrines are generally interpreted as being in an 'unfinished' state. There is, however, an alternative explanation (Evans 2009), which is that the buildings were left intentionally open to the rain, which after passing over the linga would then have exited the towers through the somasutra protruding from their north walls (and in reality, of course, would also have flowed through the front door in heavy rains) and flowed down slope into the into the newly-identified reservoir

26. Previously, I had noted that the only exception to this is the temple of Prasat Neang Khmau, which, although normally mapped as facing due west, is actually substantially off-alignment to the southwest (Evans 2009). However, recent revision of the mapping work using the lidar data has revealed very clearly the existence of a formal rectangular reservoir immediately to the southwest of, down slope of, and on the same axis as, the temple site.

27. Recent research by the author has confirmed the existence of a similar double-banked canal extending into the main reservoir of Preah Khan of Kompong Svay. As at Koh Ker, the canal at Preah Khan of Kompong Svay also extends into the reservoir from the direction of the central state temple, and also follows its principal axis.

28. In a more strictly symmetrical arrangement, one would expect there to be a similar landing immediately to the west of Prasat H (IK 279). In fact no such landing remains, although it is worth noting that there are some laterite blocks scattered in precisely this area, down the bank in the interior of the reservoir.

29. To my mind, this is the only such spatial coherence in temple positioning that can unambiguously be identified at Koh Ker. In contrast to Shimoda and Sato (2011), I do not believe that too much else can be inferred about religious concepts and sacred geography by "connecting the dots" on specific temples. The sheer quantity of sites and archacological features at Koh Ker almost guarantees that straight lines drawn along the axes of certain temples will arrive at other features of interest, and in my opinion one cannot draw any firm conclusions from the fact that some arbitrarily-chosen features happen to be so aligned, while at the same time ignoring the inconvenient fact that the placement of the great majority of features at Koh Ker does not conform to any discernible spatial pattern. 
immediately to the west. ${ }^{30}$ Interestingly, because he (incorrectly) believes that the linga were carved in situ from natural rock outcrops, Jacques (2007: 124-125) draws parallels with the natural rock carvings at a number of other locations in the Khmer Empire; two of them are Phnom Kbal Spean and Phnom Kulen, and in both of these areas, of course, there are carved sandstone elements with linga designed to sacralise a natural flow of water that ultimately ends up within an Angkorian baray. Given the identification of an adjacent, down slope reservoir here, it is likely that this was also the primary function of the linga shrines at Koh Ker.

Previous work (Evans 2009) had identified a major problem with this theory, which is the anomalous location and orientation of the other large linga shrine at Koh Ker, Prasat Kabal Chey (IK 281) (also known as 'Prasat Trapeang Russei' or 'Monument K'), which is located several hundred metres to the north of the other linga shrines, faces northeast, and did not previously appear to be upslope of any identifiable reservoir; however, further mapping work has revealed the existence of an exceptionally large Angkorian dyke that would have created an artificial reservoir immediately to the northeast of that temple as well. Subsequently, Shimoda, Ea, Chhun et al. (2011) have proposed that Prasat Khna, a collapsed linga shrine located in an area that drains directly into the Rahal, performed a similar function of sacralising water destined for the reservoir, which seems to confirm the overall pattern at Koh Ker.

The only anomalous feature in this scheme, then, is Prasat Andong Kuk, a Jayavarman VIIera hospital chapel (Jacques \& Lafond 2007: 133) that interrupts the symmetrical layout of the linga shrines to the east of Prasat Thom. However, Prasat Andong Kuk re-uses various blocks from an earlier construction; it is therefore likely that, in the original 10th century configuration, a linga shrine stood on this spot, or that one was planned, or that construction had begun. Much later, during the period of Jayavarman VII, there is an apparent desire to place Prasat Andong Kuk firmly within the formal spatial logic of the Prasat Thom axis, perhaps on the site of a collapsed or partially-completed linga shrine. ${ }^{31}$

\section{Orientation and Periodisation}

Jacques' theory (2007: 123) that the more 'conventionally oriented' temples south of the Rahal probably indicate a later period of construction is therefore quite questionable, as we can see that the vast majority of Koh Ker's temples are oriented more or less conventionally, aside from those directly associated with reservoirs. Also, as has been detailed above, the Rahal was probably a formalization of one of the curvilinear, L-shaped, northwest-oriented dams that characterised a longstanding system of water management around Koh Ker, and there is no need to believe the common assertion that Jayavarman IV must therefore have commissioned the Rahal at the beginning of his reign, or indeed even that he commissioned it at all, simply because there are Jayavarman IV temples such as

30. It is extremely unlikely, besides, that all of the linga shrines would have remained "unfinished" to exactly the same degree - i.e., missing only their roof. Furthermore, subsequent field investigations have revealed that the tops of the walls show no evidence of postholes or grooves to support a wooden roof structure; I am grateful to Anna Fluss of the German Apsara Conservation Project for confirming this for me in 2009. See more recently (Shimoda, Ea, Chhun et al. 2011).

31. There is one potential explanation for this - highly unlikely, to be sure, but not inconceivable -, which is that Prasat Kabal Chey once stood on the site of Prasat Andong Kuk, and was dismantled and rebuilt in an alternative location in the 12 th to 13 th centuries. We can see from the orientation of Prasat Andong Kuk that the preference for Jayavarman VII-era construction at Koh Ker was for buildings to be oriented to the northeast, and that the 'rebuilt' Prasat Kabal Chey may have been re-oriented accordingly. 
Prasat Banteay Pir Choan (IK 274), Prasat Plae Beng or 'Prasat D' (IK 275) and Prasat Kracap (IK 276) that face that direction. The Rahal, in either one of its original forms or in its final form, may have existed well before his reign, and in my opinion the general orientation of the structures at Koh Ker reflects this traditional system of water management, or perhaps a very early and very important brick temple later subsumed within Prasat Thom, or both. It is interesting to note, finally, that the curvilinear distribution of sites to the east of the Rahal follows almost precisely the same curvature as the series of structures identifies as embankments (A) and (F), although this may be coincidental, unless in an earlier incarnation the Rahal itself followed this particular model.

\section{Periodisation and Stylistic Homogeneity in Art and Architecture}

Although it is well-recognised that Prasat Thom in particular has a complex history of architectural development, and that Prasat Andong Kuk was built in the 12th-13th centuries, there is a general consensus in the literature that the temples of Koh Ker demonstrate a considerable temporal coherence, falling within one major period of construction in the years 921-944 AD, and that most of the variation that can be observed within the temples is to be explained by the evolution of the 'Koh Ker style' within that specific period. According to conventional accounts, this evolution was driven, in turn, by changing political and economic realitics, in particular in $928 \mathrm{AD}$ (Jacques \& Lafond 2007: 123; Parmentier 1939: 19). Unfortunately, however, very few of the temples have corroborating dates from inscriptions, and in light of new evidence presented above for the longevity of occupation at Koh Ker it is perhaps not implausible to suggest that the supposed coherence evinced by the temples may be somewhat misleading. Although this is not the place to present any detailed challenge to the notion of coherence and consistency, some further points relevant to chronology might be taken into consideration.

Firstly, there is the well-recognised phenomenon of archaism in the decorative sandstone elements of Khmer temples (Polkinghorne 2007: 157-160), in which artisans extensively referenced and reproduced 'traditional' artistic elements and motifs, even as other elements evolved. It is reasonable to suggest that the phenomenon of archaism may have been more in evidence at provincial centres than in Angkor itself, and may be attributable to the establishment of durable, localised artistic traditions that were perhaps less prone to periods of change and innovation generated by the many political and economic upheavals at Angkor. This may go a considerable way to explaining the apparent coherence in certain elements of the material culture of Koh Ker, for example in relation to statuary and certain sandstone decorative elements of temples such as lintels and colonnettes.

But how coherent is this "Koh Ker style", in fact, when one considers the full range of material culture? First of all, it is important to note something that is too easily overlooked in assessing the issue homogeneity vs. heterogeneity: that of the 80 or so masonry structures documented at Koh Ker (Shimoda \& Sato 2011) perhaps less than half have inscriptions, decorative features or structural remains that are potentially time-diagnostic; the rest are piles of generic, undecorated masonry, uncleared ruins, or equally generic pedestals that cannot be located usefully in time aside from being described as "Angkorian". Furthermore, when portable artefacts within temples such as statuary are removed from the equation, along with temples (e.g. Prasat Dan, Prasat Rolom, and Prasat Andong Kuk...) that are certainly post-Jayavarman IV, it becomes clear that only a minority of temple sites at Koh Ker can be unequivocally ascribed to the style typically held to be "definitive" of the second quarter of the 10th century, and that by and large these are represented by a handful of major monuments arrayed along 
the Rahal - Prasat Thom axis. Thus, it cannot simply be claimed, on the basis of current evidence, that any great proportion of the remains have any kind of temporal coherence, even if this may arguably be true of a small minority of well-studied monuments in the very centre of the urban complex.

Beyond that, an equally reasonable argument could be made that the temples of the Koh Ker period are, in fact, characterised by a remarkable heterogeneity, even as other aspects of material culture, such as the lintels, give the impression of consistency (Polkinghorne 2007: 283). Notwithstanding specific groupings such as the linga shrines to the east of Prasat Thom, there is a significant degree of variability in building materials; in temple orientations; and in the number, placement and dimensions of towers, enclosure walls, and ancillary buildings such as 'libraries'. Furthermore, recent, very detailed studies of smaller-scale decorated elements of temples such as pedestals and colonnettes have shown distinctive variations in form (Chen 2011; Mizoguchi \& Nakagawa 2011; Shimada 2011). ${ }^{32}$ The architect Christophe Pottier has in fact described Koh Ker as a kind of 'laboratory' for architectural experimentation and innovation (pers. comm.).

In relation to this, it is worth noting that the period designated by art historians as defining the 'Koh Ker style', normally attributed to 921-944 AD based primarily on a reading of the epigraphic corpus, is by no means a lengthy one in the general scheme of Khmer stylistic periodisation. To accept that all of these developments took place within a two decade period would be to propose that stylistic innovation and change took place at Koh Ker at a pace that was perhaps unparalleled throughout the entire pre-Angkor and Angkor periods. Paradoxically, as I have mentioned above, Parmentier and others insist on an overall coherence in the material culture of the Jayavarman IV period even while acknowledging this remarkable heterogeneity at the same time. For scholars wedded to the single-period model of Koh Ker's florescence, however, this is simply and quite arbitrarily explained away as evidence of an 'internal complexity' within a given period, rather than evidence of a need to develop a more complex or lengthy periodisation, in order to ensure that evidence from material culture conforms with the standard 19th century account of Koh Ker's history developed from a handful of dated inscriptions. Moving forward, we may have good cause to suspect that a full consideration of the entirety of the material assemblage, instead of a highly selective focus on the alleged coherence of a very small subset of material at a handful of its temples, will tend to show that perhaps Koh Ker was not so exceptional after all. Indeed, as I have shown above from a study of the broader archaeological landscape and a closer consideration of the urban infrastructure, this sense of coherence and formality breaks down dramatically and irrevocably when moving beyond simple schematic plans and reconstructions designed to restitute some kind of "ideal" original layout. Perhaps, as with other Khmer cities that developed over centuries and across various reigns, this "vast ritual complex" may be more accurately described as a vast palimpsest representing a succession of urban spaces, defying the idea of a single unitary conception of the city, and leading us eventually to a more nuanced assessment of its supposed exceptionality.

32. In an unpublished account of his visit to the site in 1952, the art historian Jean Boisselier also remarked on a series of apparent anachronisms in the decorative elements of various statues and temples at Koh Ker (EFEO Archives, Paris: Carton 1, Dossier V: Boisselier, Jean. Activités scientifiques. Rapport sur la mission exécutée dans le groupe de Koh Ker et les groupes d'Angkor-Roluoh entre le ler et le 19 avril 1952). 


\section{Inscriptions, Periodisation, and the Movement of Cities}

The Khmer epigraphic corpus, of course, does provide a relatively consistent account of the 'establishment and abandonment' of Koh Ker, compared to other categories of evidence. The inscription of Baksei Chamkrong states that Jayavarman IV "founded a city" and erected an enormous linga at Koh Ker (Cœdès 1937-66, vol. IV: 89-101). There is, however, no date provided, and the origins of Jayavarman IV himself - i.e., whether he was a local prince long established at Koh Ker or whether he relocated from Angkor - remain somewhat obscure (Jacques \& Lafond 2007: 107), although the Sdok Kak Thom inscription seems to suggest an origin for him in Angkor (Cœdès \& Dupont 1943: 119). Prasat Thom was established as the central temple of a royal capital at Koh Ker by $921 \mathrm{AD}$, as is clear from the inscriptions located there. There is some uncertainty about the status of Koh Ker as 'the' capital of the Khmer under Jayavarman IV from 921-928 AD due to the perennial debate about the true nature - and in particular, the exclusivity - of the devaraja cult that makes its first appearance in the epigraphy of Koh Ker in $921 \mathrm{AD}$, and the fact that there are other inscriptions in Cambodia which provide conflicting accounts about who was king during this period. Nonetheless, there seems to be a reasonable consensus that by 928 AD Jayavarman IV had become the undisputed king of all of the Khmer, and in the following ten years numerous inscriptions from Koh Ker and beyond attest to the far-rcaching authority of Jayavarman IV from his seat of power at that site (Briggs 1999 [1951]: 115; Coedès 1931; 1937: 47-71; Jacques \& Lafond 2007: 109; Vickery 1996: 394), while the inscription of Sdok Kak Thom confirms the transfer of royal officials to Koh Ker from Angkor (Coedès \& Dupont 1943: 119). Around $941 \mathrm{AD}$ there is a further period of uncertainty regarding kingship and succession, although the epigraphic record indicates that power transferred at around that time from Jayavarman IV to Harshavarman II (Cœè̀s 1937-66, vol. I: 260-266; Cœdès 1943: 14; Jacques 1971: 174), about whom little is known, but who is often presumed to have also ruled from Koh Ker. In any case, according to the inscriptions of Bat Chum (Coedès 1908: 216-217), in 944 AD Rajendravarman "restored the holy city of Yaśodharapura which had long remained empty", and according to the inscription of Baksei Chamkrong by $948 \mathrm{AD}$ had already begun his ambitious program of urban renewal in the area of the East Baray (Cœdès 1937-66, vol. IV: 100). From this point on, only two relatively unimportant inscriptions appear at Koh Ker: that of Prasat Dan, dating from 966 AD (Cœdès 1937-66, vol. VII: 89-90), and another from Prasat Thom dating from 1001 AD (Codès 1937-66, vol. I: 47-71).

On a closer reading, there is in fact very little in the inscriptions to support the idea that Angkor was abandoned at the beginning of the reign of Jayavarman IV, or the idea that Koh Ker was carved from the wilderness, or that Koh Ker was abandoned at the beginning of the reign of Rajendravarman. The inscriptions are quite specific about the point that it was only the king and his royal court that shifted to Koh Ker and then back to Angkor, and yet, one gets the impression from many authors (Aymonier 1900: 410; Cœdès 1908: 216-217; 1937: 71; 1968 [1964]: 114; Parmentier 1939: 15,112; Ricklefs 1967: 412) that entire cities were created from scratch and then left mostly uninhabited on account of a transient royal court in the first half of the 10th century. The only suggestion that this was actually the case comes from the inscription of Bat Chum (Coedès 1908: 216217), which describes Angkor as being deserted during the Koh Ker interlude, but it is almost impossible to imagine a city that must have had some hundreds of thousands of inhabitants in the reign of Yaśovarman I, with all of the inherent benefits of its location on the edge of the Tonle Sap, cmbarking on a wholesale relocation to Koh Ker, and then 
back again, within one or two generations. Additionally, what exactly was left 'empty', according to the Bat Chum inscription, remains undefined; a reasonable, minimalist interpretation of the text might be that the 'emptiness' was spatially, functionally and demographically limited to the specific royal and ceremonial precincts directly associated with kingship at $\Lambda$ ngkor.

Certainly, at least, there is no evidence that Koh Ker ever had that substantial a population, nor, as I have argued, would the Koh Ker area have been likely to have been able to sustain such a large population. The author of the Bat Chum inscription, I suspect, simply makes an implicit association between the transfer of a royal court and radical demographic change. The scholars who have been responsible for writing the history of 10 th century Cambodia, usually architects and epigraphers, have almost universally shared the same assumption. The assumption, in turn, has long been underpinned by the belief - since discredited by Vickery $(1986 ; 1996)$, among others - that the beginning and end of the "Koh Ker interlude" were characterised by violent and tumultuous ruptures in the royal lineage. Of course, a failure to adequately differentiate between a shift in the political centre of gravity and the 'abandonment' of the former locus of power is one of the defining characteristics of Khmer historiography; the resulting confusion is most clearly evident in 19th and 20th century scholarship on the city of Angkor, where a fundamental change in the character of textual and architectural forms in the 14th to 15 th centuries, and a southward shift in the locus of royal power, has commonly - and quite incorrectly - been interpreted as evidence of 'collapse' or 'abandonment' of the city.

\section{Conclusions}

The landscape approach detailed here has, so far, raised many more questions than it has answered about the history and archaeology of Koh Ker. Although several years of research on the issue have now been completed, many of the conclusions remain somewhat preliminary, and further field investigations are required to clarify particular issues such as the distribution of household ceramics at temple sites beyond the main group of Koh Ker, and to unravel the very complex developmental sequence of the urban areas and water management systems within the study area. Nonetheless, there have been several key outcomes: the identification of agricultural areas defined by bunded field systems and by small barrages in meander floodplains next to seasonal streams; the re-interpretation of Koh Ker's 'city walls' as merely a phase in the evolution of water management systems at the site; evidence for occupation over a period of perhaps a millennium or more; a clarification of the spatial logic of several of the temples surrounding the Rahal; the identification of very substantial impacts on the local environment such as the clearing of forest for agricultural areas and radical changes to the natural hydrology of the area; a rejection of the idea of Koh Ker as a site that is necessarily inhospitable and where urban development is unsustainable; and the development of a model of occupation and subsistence which combines some elements of the classical 'lowland' model of floodplain occupation with specific adaptations that reflect the more 'upland' character of Koh Ker.

Many of these results have broader implications for our understanding of the development of Khmer urbanism and water management systems generally. For example, the discovery of the huge northern dam at Koh Ker bears directly on the debate surrounding 'theocratic hydraulics' at Angkor. It can no longer be assumed, as some have argued in the past (Acker 1998; Stott 1992), that the vast water storage devices of the classical Angkor period served a primarily religious or symbolic function. Aside from the Rahal and the newly discovered reservoir to its north, none of the large-scale hydraulic works at Koh Ker are well integrated into the 'sacred geography' of a formal urban space. They 
do not conform to classical Indian models of urban planning and have no logical, spatial or chronological relationship with the temple sites. In fact, the morphology of the dams of Koh Ker are in some ways quite analogous to the great dams of medieval Sri Lanka, which use a cascading series of dams to exploit natural valleys for water storage. Excessive reliance on these structures to sustain a very large population may, as at Angkor, have created a built-in, systemic vulnerability to long-term trends in climatic variability and the 'mega-droughts' that are now being identified in medieval Southeast Asia. Another implication is that the data at Koh Ker support the model of 'open cities' and low-density, agrarian-based urbanism in tropical monsoon civilizations (Fletcher 2009; Pottier 2006), which is in many ways fundamentally incompatible whith the classical model of Khmer urbanism, which posits a succession of well-planned and formally laid-out spaces neatly defined by enclosures.

A great deal of work remains to be done, and this report has identified many potentially useful lines of enquiry. What is urgently required for Koh Ker is a series of palaeoenvironmental studies in order to clarify stages in the development of the site from a forested area into a densely inhabited and cultivated space, and to identify the chronology of the 'abandonment' of the area, similar to what has been achieved at Angkor (Penny, Pottier, Fletcher et al. 2006). Large-scale excavations are required at occupation sites and across hydraulic structures in order to clarify the stages of their development. Modern dating techniques could be used to produce a chronology of monuments with absolute dates (Wilson, Carter, Hall et al. 2009), in order to resolve the issue of Koh Ker's development as a capital and as a religious centre. In terms of landscape archaeology, the greatest potential at Koh Ker probably lies in the further analysis of recently-acquired lidar remote sensing technology to the area, and perhaps the extension of existing lidar coverage, in order to produce an extremely accurate, high-resolution model of the surface beneath the vegetation over the entire region. This will aid in the identification of remnant field systems, occupation mounds and ponds, and allow the development of extremely precise hydrological models with a view to understanding the role of water management systems in the rise and fall of Koh Ker as a major urban centre of the Khmer Empire.

The research on Koh Ker described here was begun many years ago with the idea that Koh Ker was essentially a single period site, and that it would therefore provide an excellent case study for revealing patterns of settlement and water management that were characteristic of the second quarter of the 10th century AD. Parmentier (1939: 15) was fascinated with Koh Ker for similar reasons. In his view, the fact that so much was achieved there in such a constrained period of time meant that it had the potential to reveal a period of Khmer art and architecture with great clarity, without the confusion and uncertainty commonly caused by the spatial and temporal complexities of Angkor. Paradoxically, however, what has emerged from recent research on Koh Ker is that it is indeed a special case, but not because it was ephemeral: but rather, because of the dissonance between the ostensibly brief periods of iconographic and epigraphic output and the much broader evidence for a very long and complex history of occupation. Once again, this underscores the fundamental difficulties of relying primarily on the artistic and literary expressions of the royal court, religious elites and the nobility as a basis for understanding the history of Khmer civilisation. It is worth noting, to take just one example, that the defining feature of the archaeological landscape of Koh $\mathrm{Ker}$ - its vast and extensive water management system, quite different to that of Angkor - is not once mentioned or even alluded to within the epigraphic corpus. Although the method has served us well since the 19th century, it is perhaps time to seriously re-evaluate the limits to the inferences that can be drawn from a selective and subjective consideration of inscriptional sources and decorative 
carvings about the broader social, cultural, historical and environmental context in which they were produced. Above all, it highlights the urgent need for large-scale, systematic archaeological studies at Koh Ker, driven by fundamentally different research questions than those that have been asked of the archaeological record in the past.

\section{Acknowledgements}

This project is principally funded by the Australian Research Council (DP0880490), with contributions from the Wenner-Gren Foundation, the National Geographic Committee for Research and Exploration, the University of Sydney and the Robert Christie Foundation. Logistical and administrative support comes from the University of Sydney (in particular the School of Philosophical and Historical Inquiry and Arts eResearch) and the Apsara National Authority (in particular Soueng Kong, Ea Darith, Phin Samnang and Eric Llopis). The GeoEye Foundation provided Ikonos satellite data free of charge, while the German space agency, DLR, also freely contributed TerraSAR-X satellite data within the framework of an agreement with UNESCO. Airborne laser scanning was acquired within the framework of the Khmer Archaeology LiDAR Consortium (APSARA National Authority, University of Sydney, the Archaeology and Development Foundation Phnom Kulen Program, École française d'Extrême-Orient, Société Concessionnaire d'Aéroport, Hungarian Indochina Company, Japan-APSARA Safeguarding Angkor, and the World Monuments Fund) by PT McElhanney of Indonesia and Helistar. I am grateful to Till Sonnemann for facilitating the TerraSAR-X data acquisition and for conducting the ground penetrating radar assessment in 2009. Eddie Smith and Donald Cooney piloted several aerial surveys of the area. I am indebted to Son Chanthouen, Tom Phalla, Ngaire Richards, Federico Carò, Jérémy Berthelomeau, Phin Samnang, Arianna Traviglia and Stephen White for invaluable fieldwork assistance. Christophe Pottier and Roland Fletcher have provided advice, guidance and practical support at all stages of the project. I am grateful to the staff of the Koh Ker Project for photos of their surface collections at Prasat Boh Lohon; to Terry Lustig for advice on hydrology; to Anna Fluss for architectural investigations; to Li Baoping and John Miksic for advice on ceramics; to Eric Llopis and Ea Darith for providing copies of unpublished Apsara reports for my use; to Eileen Lustig for assistance with epigraphic data; to Mitch Hendrickson for data relating to Angkorian roads; to Martin Polkinghorne for advice on art historical aspects of Koh Ker; to Martin King for crucial administrative support; and finally, to So Malay for providing translations of unpublished Khmer-language material. Christophe Pottier and Martin Polkinghorne provided suggestions on earlier versions of this manuscript; however, all errors and inaccuracies are my own.

\section{BIBLIOGRAPHY}

ACKkR, Robert

1998 "New geographical tests of the hydraulic thesis at Angkor", South East Asia Research 6, p. 5-47.

2006 "Hydrology and the Siting of Yasodharapura", in Phnom Bakheng Workshop on Public Interpretation, Angkor Park, Siem Reap, Cambodia, December 4-6, 2005: Conference Proceedings, Jane Clark Chermayeff and Associates (ed.), Siem Reap, Center for Khmer Studies, p. 73-86. 
Aymonier, Étienne

1900 Le Cambodge : le rovaume actuel, Paris, Ernest Leroux.

BELENYESY, Károly

2011 "Report on archaeological research work in the territory of Prasat Kracap at Koh Ker: 7 March 2011-25 April 2011", in Koh Ker Project: Annual Report 2011. Zsuzsanna Renner (ed.), Budapest, Magyar Indokína Társaság Kft., p. $22-41$.

Bishop, Paul, Dan Plinny, Miriam T. Stark \& Marian Scott

2003 "A 3.5ka record of paleoenvironments and human occupation at Angkor Borei, Mekong delta, southern Cambodia", Geoarchaeology 18, p. 359-393.

Bollbet, Jean

1979 Le Phnom Kulen et sa région: Carte et commentaire, Paris, École française d'Extrême-Orient.

BOURDONNEAU, Éric

2011 "Nouvelles recherches sur Koh Ker (Chok Gargyar). Jayavarman IV et la maîtrise des mondes", Monuments et mémoires 90, p. 93-141.

Briggs, Lawrence Palmer

1999 [1951] The Ancient Khmer Empire, Bangkok, White Lotus.

Bruguiter, Bruno

2000 "Les ponts du Cambodge ancien. Aménagement ou contrôle du territoire?", Bulletin de l'École française d'Extrême-Orient 88, p. 529-551.

Blckley, Brendan M., Kevin J. Anchukaitis, Daniel Penny, Roland Fi.ftcher, Edward

R. Cook, Masaki Sano, Le Canh Nam, Aroonrut Wichifnkeeo, Ton That Minh \&

TRUONG; MAI HONGi

2010 "Climate as a contributing factor in the demise of Angkor, Cambodia", Proceedings of the National Academy' of Sciences of the USA 107, p. 6748-6752.

CARò, Federico, Janet Dolcilas \& IM Sokrithy

2009 "Towards a quantitative petrographic database of Khmer stone materialsKoh Ker style sculpture", Archaeometry 52, p. 191-208.

Caró, Federico \& IM Sokrithy

2012 "Khmer sandstone quarries of Kulen Mountain and Koh Ker: a petrographic and geochemical study", Journal of Archaeological Science 39, p. 1455-1466.

Chandili: David P.

2000 A History of Cambodia, Chiang Mai, Silkworm Books.

Chen Chankatana

2011 Le Site de Koh Ker et le Règne de Javavarman $I V$, unpublished PhD Thesis, université Paris III-Sorbonne Nouvelle.

ChHOM KLNTHF:A

2011 Inscriptions of Koh Ker 1, Budapest, The Hungarian Southeast Asian Research Institute.

Cor:, Michael

2003 Angkor and the Khmer civilization, New York, Thames \& Hudson.

CGEDÈs, George

1908 "Les inscriptions de Bat Chum", Journal asiatique, September-October, p. 213-252. 
1931 "La date de Koh Ker", Bulletin de l'École française d'Extrême-Orient 31, p. $12-18$.

1937-66 Inscriptions du Cambodge, Hanoi, Paris, École française d'Extrême-Orient, 8 vol.

1943 "Nouvelles précisions sur les dates d'avènement de quelques rois des dynasties angkoriennes", Bulletin de l'École française d'Extrême-Orient 43, p. 12-16.

1968 [1964] The Indianized States of Southeast Asia, Canberra, Australian National University Press.

Cafiès, George \& Pierre Dupont

1943 "Les stèles de Sdŏk Kăk Thoṃ, Phnoṃ Sandak et Práh Vihār", Bulletin de l'École française d'Extrême-Orient 43, p. 56-154.

Crocker, Charles D.

1962 The general soil map of the Kingdom of Cambodia and the exploratory survey of the soils of Cambodia, Phnom Penh, Royal Cambodian Government Soil Commission/USAID.

Delaporte, Louis

1880 Voyage au C'ambodge : l'architecture khmer, Paris, Delagrave.

DumarçAy, Jacques \& Pascal Royìre

2001 Cambodian Architecture Eighth to Thirteenth Centuries, Boston, Brill.

EA Darith

2011 "Preliminary report on Khmer ceramics from archaeological investigations at Prasat Kracap", in Koh Ker Project: Annual Report 2011, Zsuzsanna Renner (ed.), Budapest, Magyar Indokína Társaság Kft., p. 42-45.

Ea Darith, Chhay Visoth, Chap Sopheara, lam Sopheak, Loeung Ravatey, Sok

Sovannara Keo \& Em Socheata

2008 "New Data on Khmer Kiln Sites", in Interpreting Southeast Asia's Past, Volume 2: Monument, Image and Text, Elizabeth A. Bacus, Ian Glover \& Peter D. Sharrock (eds.), Singapore, NUS Press, p. 275-284.

Evans, Damian

2007 Putting Angkor on the Map: A New Survey of a Khmer 'Hydraulic City' in Historical and Theoretical Context, unpublished PhD Thesis, University of Sydney.

2009 "Towards a Landscape Archaeology of Koh Ker: Methods, Issues and Recent Research", in Jaya Koh Ker Project: Annual Report 2009, János Jelen \& Róbert Kuszinger (eds.), Budapest, Royal Angkor Foundation, p. 25-63.

2010 "Applications of archaeological remote sensing in Cambodia: an overview of Angkor and beyond", in Space, Time, Place: Third International Conference on Remote Sensing in Archaeology, Maurizio Forte, Stefano Campana \& Claudia Liuzza (eds.), Oxford, Archaeopress, p. 353-366.

Evans, Damian \& Elizabeth Moylan

2013 "Pixels, Ponds and People: Mapping Cultural and Archaeological Landscapes in Cambodia Using Historical Aerial Imagery", in The Spy in the Sky: Archaeology from aerial archives, William Hanson \& Ioana Oltean (eds.), New York, Springer, p. 291-313. 
Evans, Damian, Christophe Pottifer, Roland Fletcher, Scott Hensley, Ian Tapley, Anthony MiLNE \& Michael BARBeTTI

2007 "A comprehensive archaeological map of the world's largest preindustrial settlement complex at Angkor, Cambodia", Proceedings of the National Academy of Sciences of the USA 104, p. 14277-14282.

EVAns, Damian \& Arianna TkAviglia

2012 "Uncovering Angkor: Integrated Remote Sensing Applications in the Archaeology of Early Cambodia", in Satellite Remote Sensing: A New Tool for Archaeology, Rosa Lasaponara \& Nicola Masini (eds.), New York, Springer, p. 197-230.

FLETCHER, Roland

2000-01 "A.R. Davis Memorial Lecture. Seeing Angkor: New views of an old city", Journal of the Oriental Society of Australia 32-33, p. 1-25.

2009 "Low-Density, Agrarian-Based Urbanism: A Comparative View", Insights 2, p. $1-19$.

Fletcher, Roland, Michael Barbetti, Damian H. Evans, Heng Than, Im Sokrithy,

Khieu Chan, Daniel Penny, Christophe Pottier \& Tous Somaneath

2003 "Redefining Angkor: structure and environment in the largest, low density urban complex of the pre-industrial world", Udaya, Journal of Khmer Studies 4, p. 107-121.

Fletcher, Roland J., Daniel Penny, Michael Barbetti, Christophe Pottier, Heng

Than, Khieu Chan \& Tols Somaneath

2006 "The Greater Angkor Project 2005-2009: Issues and Program", in Uncovering Southeast Asia's Past: selected papers from the 10th International Conference of the European Association of Southeast Asian Archaeologists, Elizabeth A. Bacus, lan Glover \& Vincent Pigott (eds.), Singapore, NUS Press, p. 347-354.

Fletcher, Roland, Ian Johnson, Eleanor Bruce \& Khuon Khun-Neay

2007 "Living With Heritage: site monitoring and heritage values in Greater Angkor and the Angkor World Heritage Site, Cambodia", World Archaeology 39, p. 385-405.

Fletcher, Roland, Daniel Penny, Damian Evans, Christophe Potrler, Michael Barbettı, Matti Kummu, Terry Lustig \& Authority for the Protection and Management of Angkor and the Region of Siem Reap (APSARA) Department of Monuments and Archaeology Team

2008 "The water management network of Angkor, Cambodia", Antiquity 82, p. 658-670.

FleTCHER, Roland \& Christophe PotTIFR

2002 "The Gossamer city: A new inquiry", Museum International 54, p. 23-27.

Fletcher, Roland, Christophe Pottier, Damian Evans \& Matti Klimmu

2008 "The development of the water management system at Angkor: A provisional model", Bulletin of the Indo-Pacific Prehistory Association 28, p. 57-66.

GaUCH:R, Jacques

2003 "New Archaeological Data on the Urban Space of the Capital City of Angkor Thom", in Fishbones and Glittering Emblems: Southeast Asian Archaeology 2002, Anna Karlström \& Anna Källén (eds.), Stockholm, Museum of Far Eastern Antiquities, p. 233-242. 
Goloubew, Victor

1941 "L'hydraulique urbaine et agricole à l'époque des rois d'Angkor", Bulletin économique de l'Indochine 1, p. 9-18.

Grosiser, Bernard Philippe

1952 "Milieu et évolution en Asie", Bulletin de la Société des études indochinoises 27, p. 295-332.

1962 The Art of Indochina: Including Thailand, Vietnam, Laos and Cambodia, New York, Crown Publishers Inc.

1979 "La cité hydraulique angkorienne: Exploitation ou surexploitation du sol ?", Bulletin de l'École française d'Extrême-Orient 66, p. 161-202.

HENDRICKSON, Mitch

2007 Arteries of Empire: An operational study of transport and communication in Angkorian Southeast Asia, unpublished PhD Thesis, University of Sydney.

2008 "New evidence of brown glaze kilns along the East Road from Angkor", Bulletin of the Indo-Pacific Prehistory Association 28, p. 52-56.

Higham, Charles

2001 The Civilisation of Angkor, London, Weidenfeld \& Nicolson.

Ishizawa Yoshiaki \& Tamura Hitoshi

1999 Along the Royal Roads to Angkor, Tokyo, Weatherill.

JACQUES, Claude

1971 "Études d'épigraphie cambodgienne, VI. Sur les données chronologiques de la stèle de Tûol Ta Pec (K. 834)", Bulletin de l'École française d'ExtrêmeOrient 58, p. 163-176.

1978 "Études d'épigraphie cambodgienne, X. Autour de quelques toponymes de l'inscription de Pràsàt Trapã̀n Run K 598. La capitale angkorienne de Yaśovarman I ${ }^{\text {er }}$ à Sūryavarman Ier", Bulletin de l'École française d'ExtrêmeOrient 65, p. 281-321.

JACQuES, Claude \& Philippe LAFOND

2007 The Khmer Empire: Cities and Sanctuaries, from the Fifth to the Thirteenth Century, Bangkok, River Books.

Japan International CoOperation Agency

1999 Cambodia Reconnaissance Survey Digital Data, Japan, Japan International Cooperation Agency (JICA).

Kummu, MatTI

2009 "Water management in Angkor: Human impacts on hydrology and sediment transportation", Journal of Environmental Management 90, p. 1413-1421.

Lı Baoping

2011 "Preliminary report on Chinese ceramics found at Prasat Kracap and Boh Lahong", in Koh Ker Project: Annual Report 2011, Zsuzsanna Renner (ed.), Budapest, Magyar Indokína Társaság Kft., p. 46-57.

LIEBERMAN, Victor \& Brendan BuCKLEY

2012 "The Impact of Climate on Southeast Asia, circa 950-1820: New Findings", Modern Asian Studies 46, p. 1049-1096.

LlopIs, Eric

2009 Éléments d'information et d'archéologie récente: Kohker 2009, Siem Reap, Apsara Authority. 
LUNET DE LAJONQUIÈRE, Étienne

1902 Inventaire descriptif des monuments du Cambodge, Paris, École française d'Extrême-Orient.

Lustig, Eileen

2001 Water and the Transformation of Power at Angkor, 10th to 13th Centuries A.D., Unpublished BA (Hons) Thesis, University of Sydney.

2009 Power and Pragmatism in the Political Economy of Angkor, unpublished PhD Thesis, University of Sydney.

Lustig, Eileen, Damian H. Evans \& Ngaire Richards

2007 "Words across Space and Time: An Analysis of Lexical Items in Khmer Inscriptions, Sixth-Fourteenth Centuries CE", Journal of Southeast Asian Studies 38, p. 1-26.

Ly Vanna, Ea Darith, Loeu Chanora, Phin Samnang, Phan Makara, Lon Votey \&

Pich RANETH

2010 "Archaeological Excavations at the Koh Ker Complex", in Koh Ker project: Annual Report 2010, Ágnes Vajda (ed.), Budapest, Magyar Indokína Társaság Kft., p. 11-20.

MaI.LERET, Louis

1959 "Ouvrages circulaires en terre dans l'Indochine méridionale", Bulletin de l'École française d'Extrême-Orient 49, p. 409-434.

MeKong River Commission

2002 Soil Map of the Lower Mekong Basin, Vientiane, Mekong River Commission.

2005 Overview of the Hydrology of the Mekong Basin, Vientiane, Mekong River Commission.

Mizoguchi Akinori \& Takeshi Nakagawa (eds.)

2011 Koh Ker and Beng Mealea: Two large monuments at the eastern portion of the Khmer Empire, Japan, Grants-in-Aid for Scientific Research (A): Overseas Project Japan Society for the Promotion of Science 2007 to 2010.

Moore, Elizabeth $\mathrm{H}$.

2000 "Angkor Water Management, Radar Imaging, and the Emergence of Urban Centres in Northern Cambodia", The Journal of Sophia Asian Studies 18, p. 39-52.

Moria Tomio, Yosiyasu Matsumura \& Yosio Akama

2002 "Geological Study on Angkor Monuments: Part 3", Memoirs of the Tohoku Institute of Technology. Series 1. Science and Engineering 22, p. 23-39.

Nesbitt, Harry J (ed.)

1997 Rice production in Cambodia, Manila, International Rice Research Institute.

PARME:NTIER, Henri

1939 L'art khmèr classique: Monuments du quadrant nord-est, Paris, Les éditions d'art et d'histoire.

Penny, Daniel, Christophe Pottllik, Roland Filtchle, Michael Barbetti, David Fink \& Quan HuA

2006 "Vegetation and land-use at Angkor, Cambodia: a dated pollen sequence from the Bakong temple moat", Antiquity 80, p. 599-614. 
Penny, Daniel, Christophe Potrifr, Matti Kummu, Roland Fi.Ftcher, Ugo Zoppi \& Tous SOMANEATH

2007 "Hydrological history of the West Baray, Angkor, revealed through palynological analysis of sediments from the West Mebon", Bulletin de l'École française d'Extrême-Orient 92, p. 497-521.

Phann Nady, Chrin Sarong, Chan Sovichetra, Chamrofun Chamrong \& Bruno

BRUGUIER

2007 Carte archéologique du Cambodge, Phnom Penh, Kim Long.

POLKINGHORNe, Martin

2007 Makers and Models: Decorative Lintels of Khmer Temples, 7th to 11th Centuries, unpublished PhD Thesis, University of Sydney.

PotTIER, Christophe

1999 Carte archéologique de la région d'Angkor. Zone Sud, unpublished PhD Thesis, Université Paris III-Sorbonne Nouvelle.

2000a "À la recherche de Goloupura", Bulletin de l'École française d'ExtrêmeOrient 87, p. 79-107.

2000b "Some Evidence of an Inter-relationship between Hydraulic Features and Rice Field Patterns at Angkor during Ancient Times", The Journal of Sophia Asian Studies 18, p. 99-120.

2006 "Searching for Goloupura", in Phnom Bakheng Workshop on Public Interpretation, Jane Clark Chermayeff \& Associates (ed.), Phnom Penh, Centre for Khmer Studies, p. 41-72.

2007 "Under the Western Baray Waters", in Uncovering Southeast Asia's Past: Selected Papers from the 10th International Conference of the European Association of Southeast Asian Archaeologists: the British Museum, London, 14th-17th September 2004, Elizabeth A. Bacus, Ian Glover \& Vincent Pigott (eds.), Singapore, NUS Press, p. 298-309.

PotTIER, Christophe \& Annie Bollle

2009 "Le Prasat Trapeang Phong à Hariharâlaya : histoire d'un temple et archéologie d'un site", Aséanie 24, p. 61-90.

Pottier, Christophe, Annie Boll.e, Eric Llopis, Dominique Soutif, Cyril Tan, Jean-

Baptiste Chevance, Kong Vireak, Chea Socheat, Sum Sang, Fabrice Demeter, Anne-

Marie BaCon, Nicolas Bouchet, Caroline Souday \& Mélanie Frelat

2005 Mission archéologique franco-khmère sur l'aménagement du territoire angkorien (MAFKATA). Campagne 2005: Rapport, Siem Reap, École française d'Extrême-Orient.

RENNER, Zsuzsanna (ed.)

2011 Koh Ker Project: Annual Report 2011, Budapest, Magyar Indokína Társaság Kft.

RichaRds, Ngaire

2007 Prehistoric and early historic settlement around Banteay Chmar, northwest Cambodia, unpublished BA(Hons) Thesis, University of Sydney.

RiCKL_EFs, Merle C.

1967 "Land and Law in the Epigraphy of Tenth-Century Cambodia", Journal of Asian Studies 26, p. 411-420. 
Rocks, David

2009 "Ancient Khmer Quarrying of Arkose Sandstone for Monumental Architecture and Sculpture", Proceedings of the Third International Congress on Construction History, Cottbus, May 2009, p. 1235-1242.

Sanderson, David, Paul Bishop, Miriam T. STARK \& Joel Spencer

2003 "Luminescence dating of anthropogenically reset canal sediments from Angkor Borei, Mekong Delta, Cambodia", Quaternary Science Reviews 22, p. $1111-1121$.

Sano Masaki, Brendan M. Buckley \& Tatsuo SwedA

2009 "Tree-ring based hydroclimate reconstruction over northern Vietnam from Fokienia hodginsii: eighteenth century mega-drought and tropical Pacific influence", Climate Dynamics 33, p. 331-340.

Sato Katsura

2010 クメール占代都市「チョック・ガルギャー」研究序説: Ancient Khmer City Chok Gargyar Reviewed, unpublished PhD Thesis, Waseda University.

SHIMADA Mariko

2011 "Study of Pedestal Remains for Linga and Statue of Gods", in Koh Ker and Beng Mealea: Two large monuments at the eastern portion of the Khmer Empire, Akinori Mizoguchi and Takeshi Nakagawa (eds.), Japan, Grantsin-Aid for Scientific Research (A): Overseas Project Japan Society for the Promotion of Science 2007 to 2010, p. 70-75.

Shimoda Ichita, Ea Darith, Chrun Menhong, Chan Vitharong, Som Nang, Mitsumasa Ishizuka, Syohei Toyonaga \& Robert McCarThy

2011 "Archaeological Excavation Survey of the Large Linga Pedestals at Koh Ker Monuments", in Koh Ker and Beng Mealea: Two large monuments at the eastern portion of the Khmer Empire, Akinori Mizoguchi and Takeshi Nakagawa (eds.), Japan, Grants-in-Aid for Scientific Research (A): Overseas Project Japan Society for the Promotion of Science 2007 to 2010, p. 120-128.

SHIMODA Ichita \& Katsura SATO

2011 "Religious Concept in the Layout of the Ancient City of Koh Ker", in Koh Ker and Beng Mealea: Two large monuments at the eastern portion of the Khmer Empire, Akinori Mizoguchi \& Takeshi Nakagawa (eds.), Japan, Grants-in-Aid for Scientific Research (A): Overseas Project Japan Society for the Promotion of Science 2007 to 2010, p. 39-62.

Shimoda Ichita, Kenji Uchida, Chhun Menhong, Chan Vitharong, Som Nang, Mitsumasa Ishizuka, Syohei Toyonaga, Robert MCCarThy, Mariko Shimada \& Kaori Shiraishi

2011 "Preliminary Research on the "Andong Preng" Site, Koh Ker Monument", in Koh Ker and Beng Mealea: Two large monuments at the eastern portion of the Khmer Empire, Akinori Mizoguchi \& Takeshi Nakagawa (eds.), Japan, Grants-in-Aid for Scientific Research (A): Overseas Project Japan Society for the Promotion of Science 2007 to 2010, p. 129-139.

Sipos, György, Károly Bilı́n NYtsy \& Gábor Bozsó

2011 "Thermoluminescence dating of pottery fragments from Koh Ker, Cambodia, Preliminary Results", in Koh Ker Project: Annual Report 2011, Zsuzsanna Renner (ed.), Budapest, Magyar Indokína Társaság Kft., p. 58-72. 


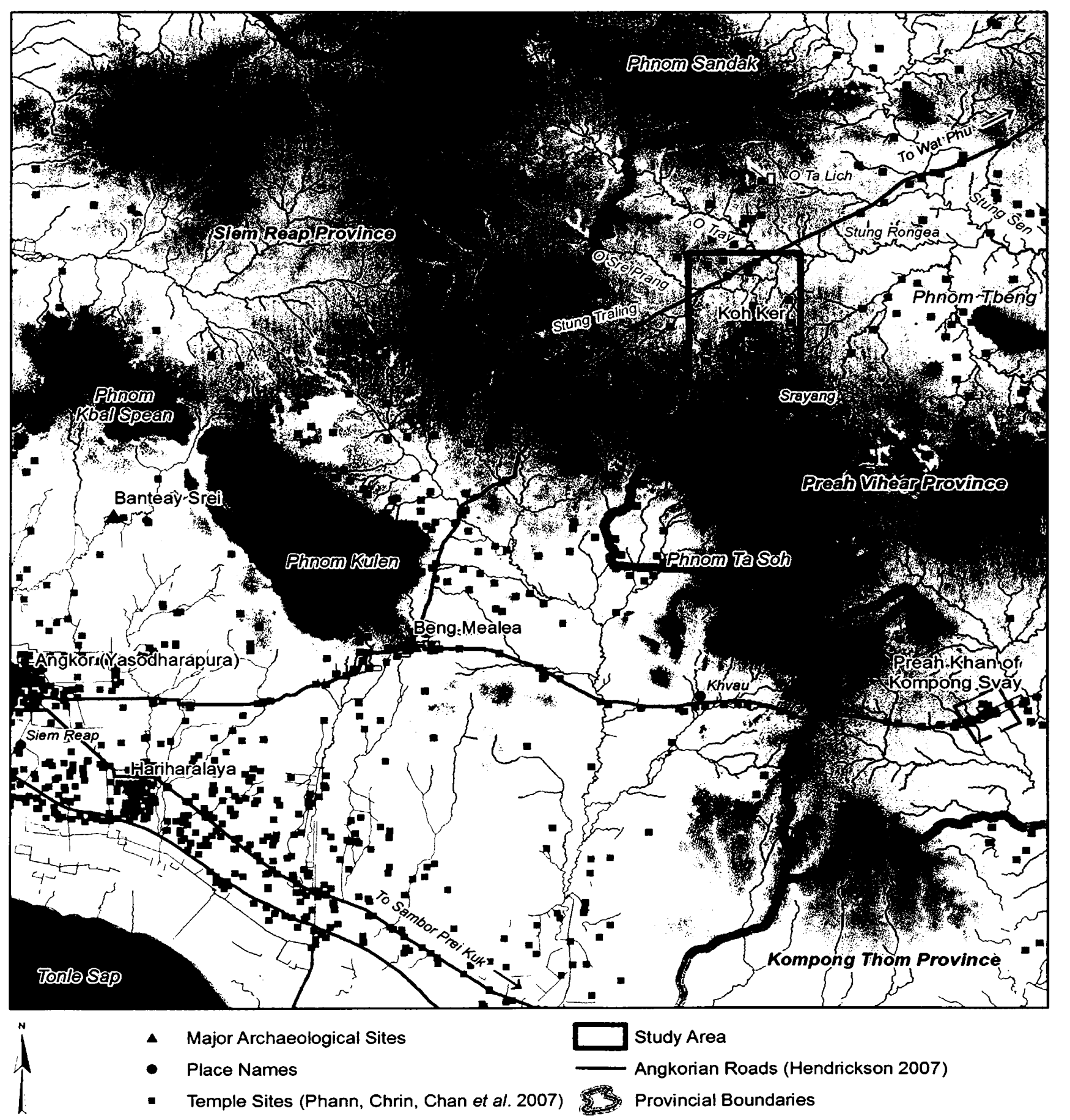

$0 \quad 15 \quad 30 \quad 60$ Kibmeters 


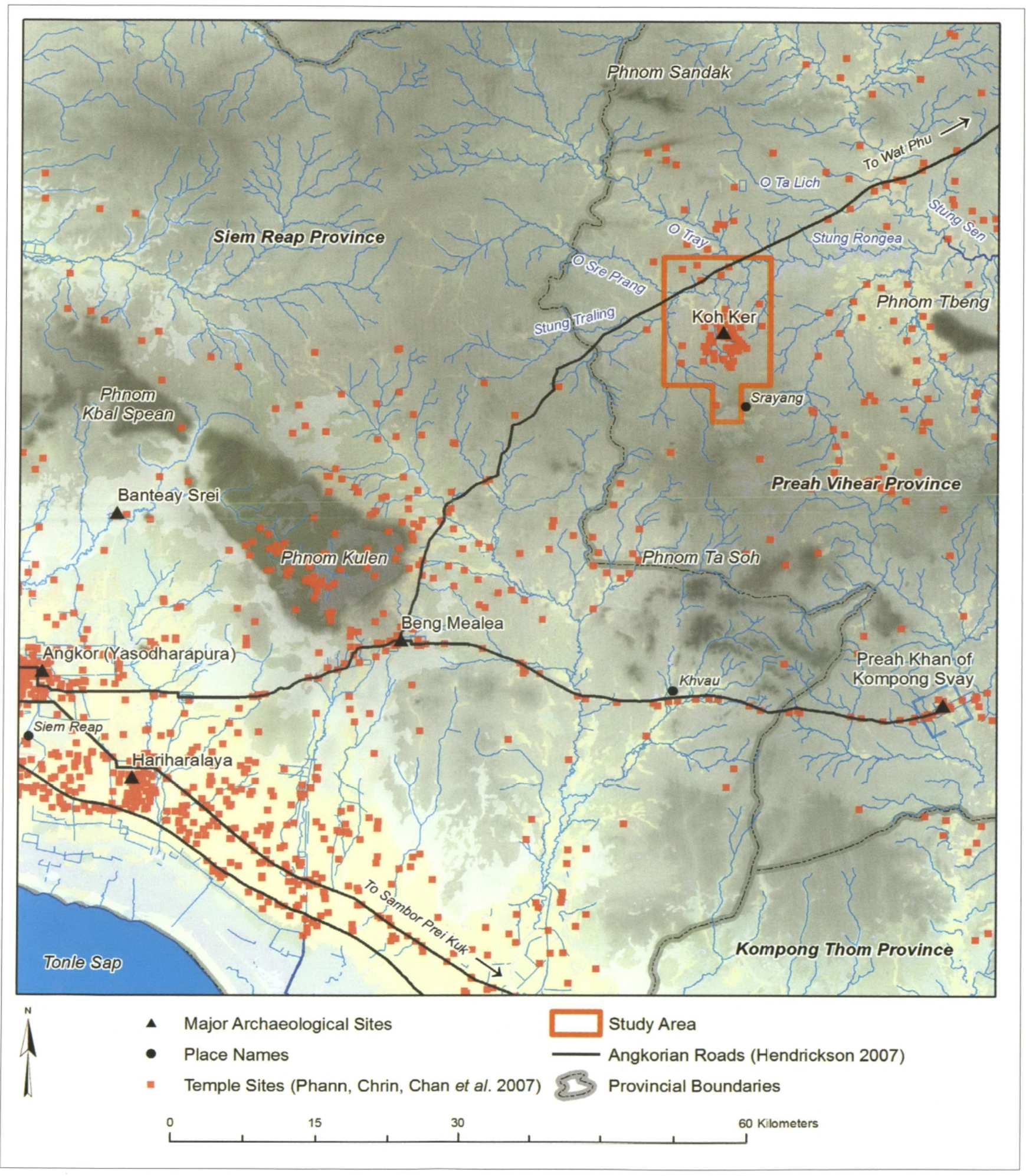

Fig. 1: Overview map of Koh Ker in relation to regional archacological sites (background data courtesy of the Japan International Cooperation Agency and NASA Shuttle Radar Topography Mission). 

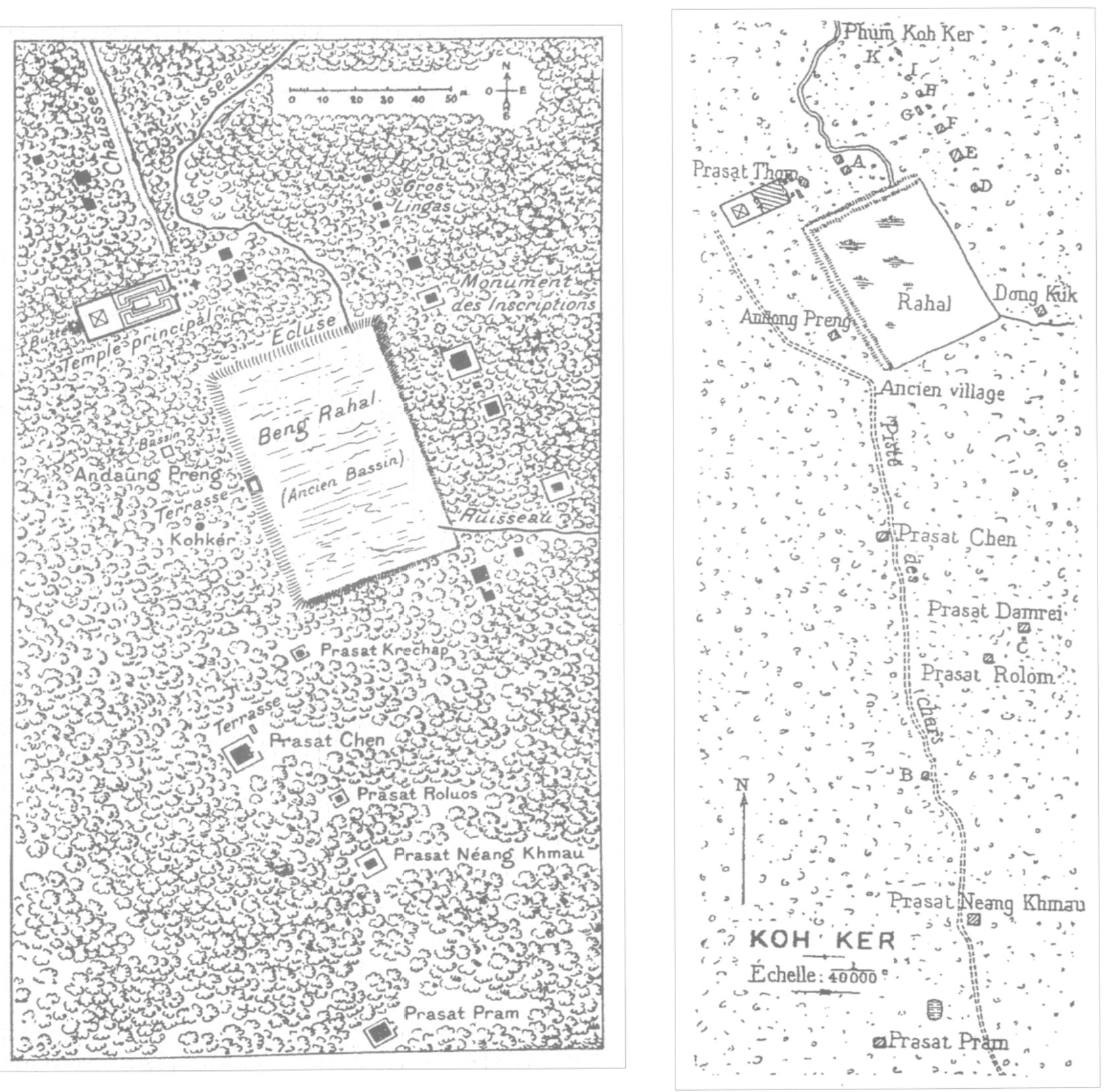

Fig. 2: The maps of Aymonier (left) and Lunet de Lajonquière (right). 


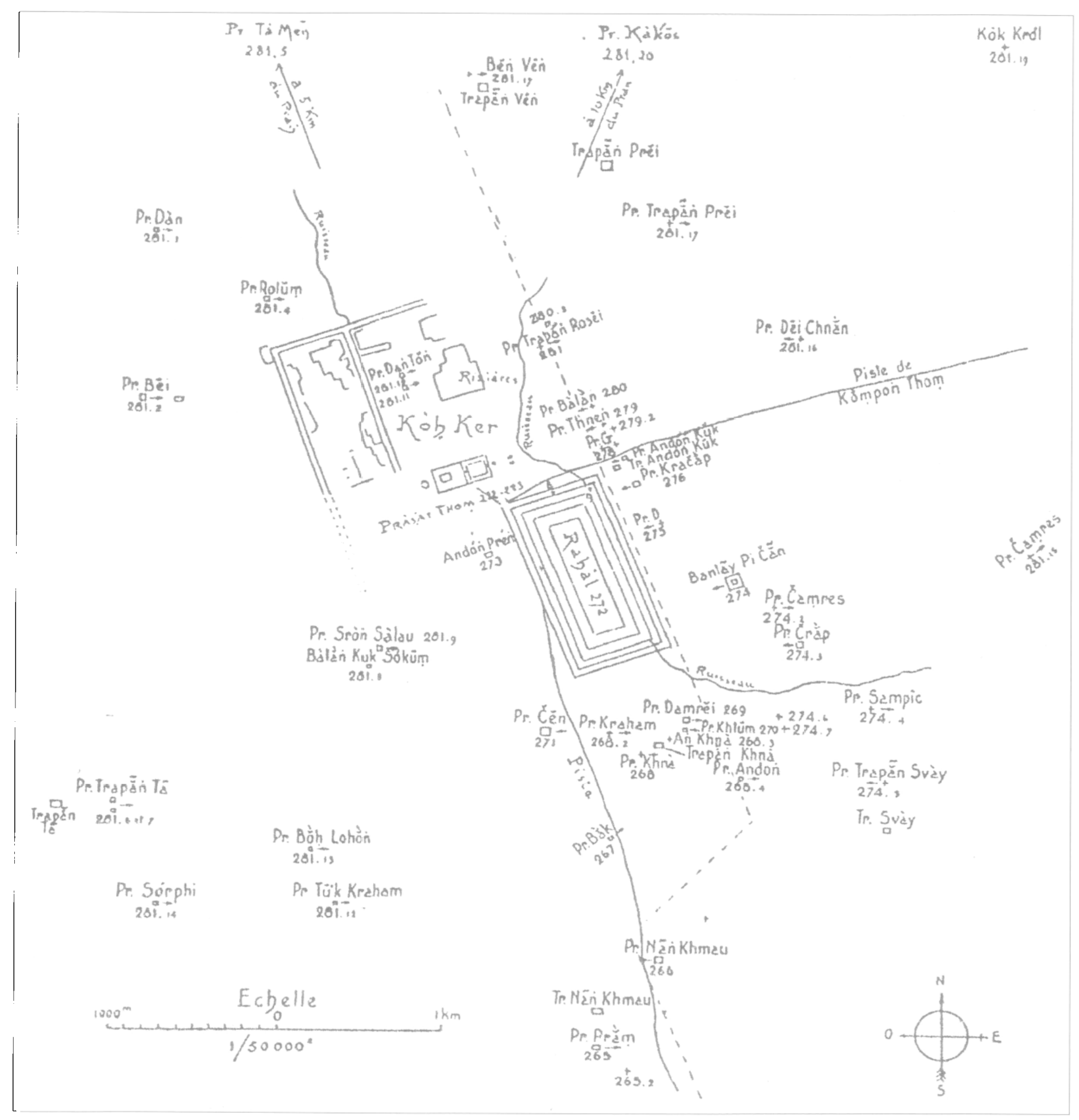

Fig. 3: Parmentier's map of Koh Ker. 


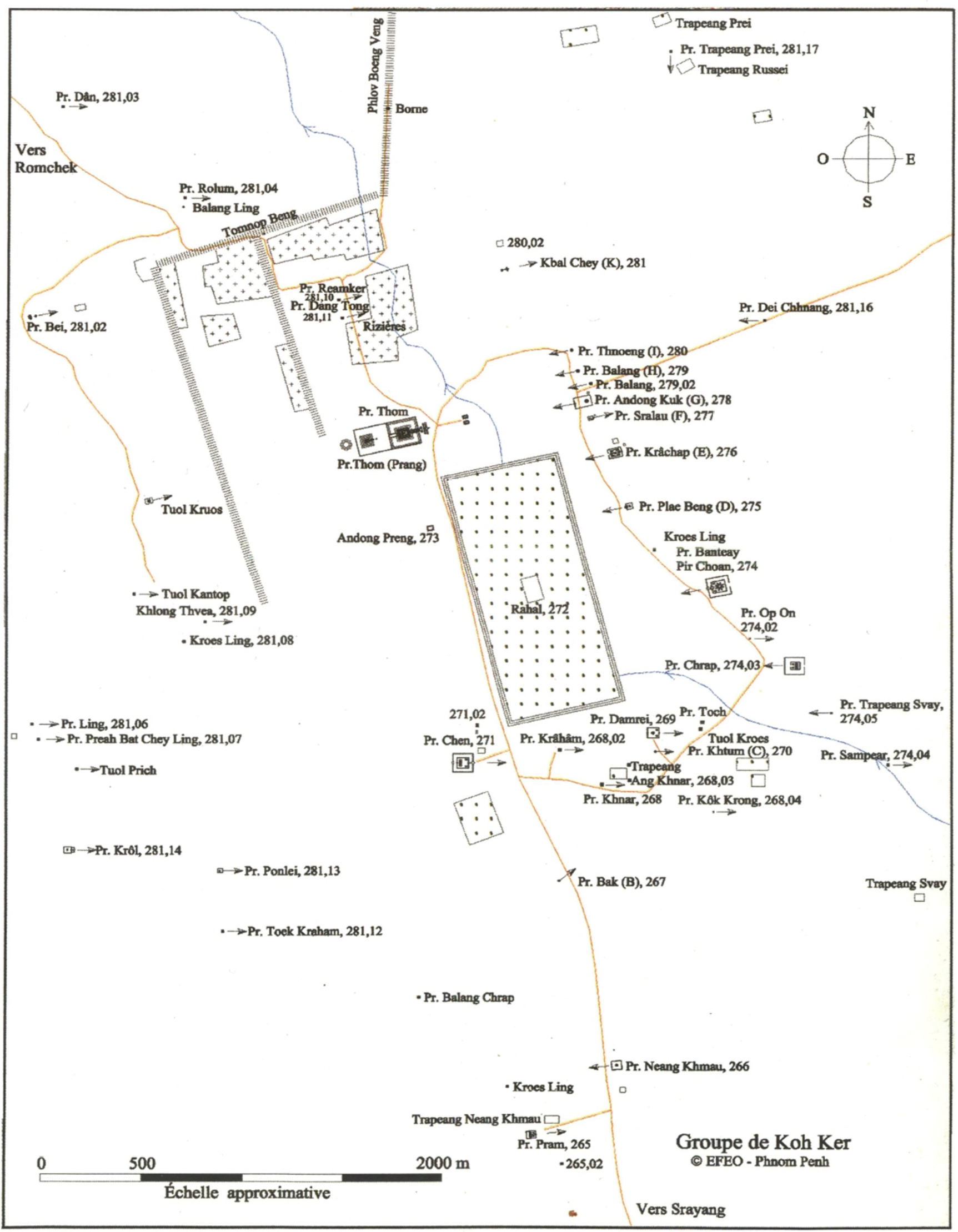

Fig. 4: Map of Koh Ker by Phann. Chrin. Chan et al. 


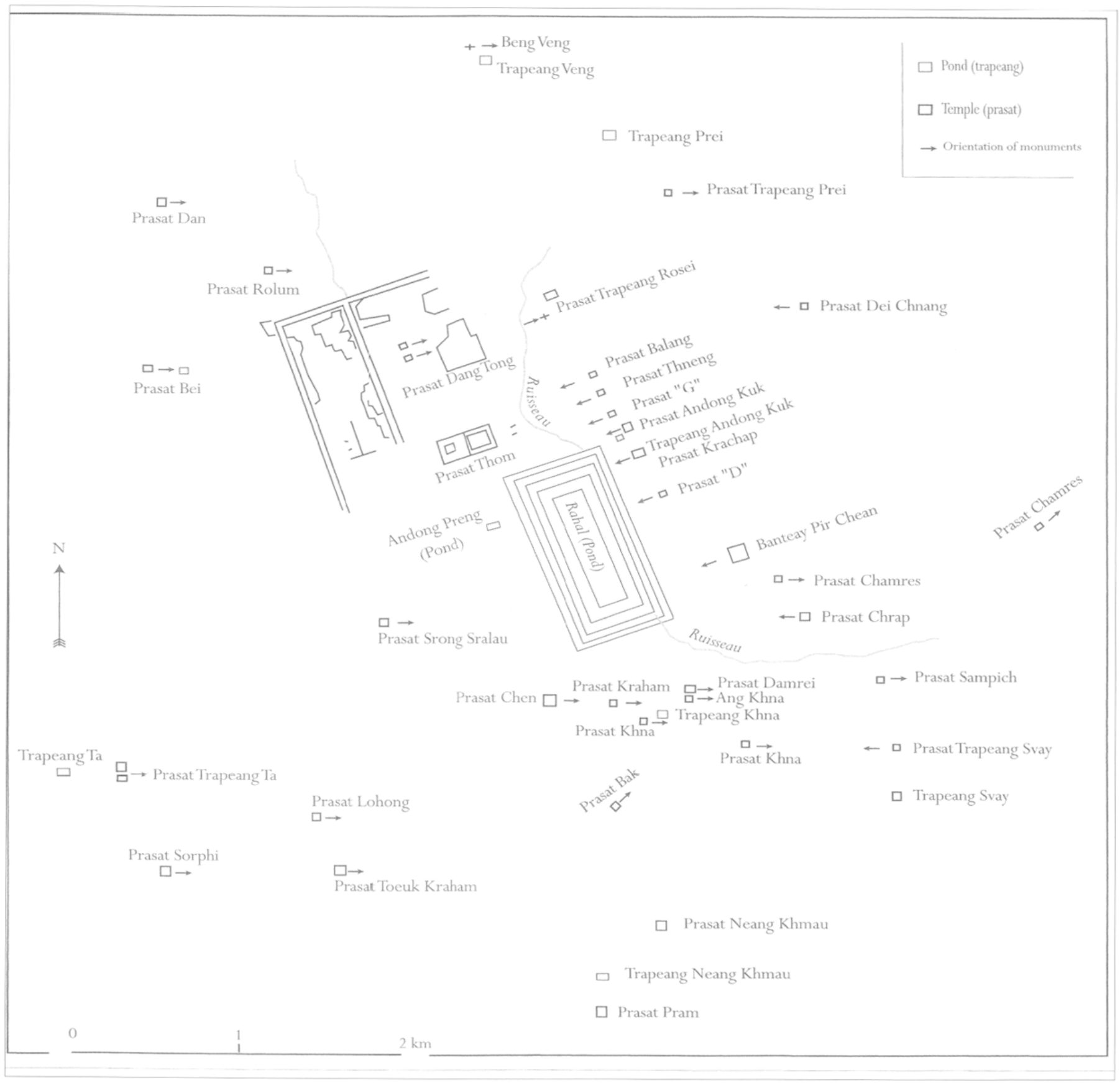

$\Delta$ Fig. 5: Jacques' map of Koh Ker.

-Fig. 6: A new map of Koh Ker (for details and labels in the central area see Figures 8 and 10 ). 


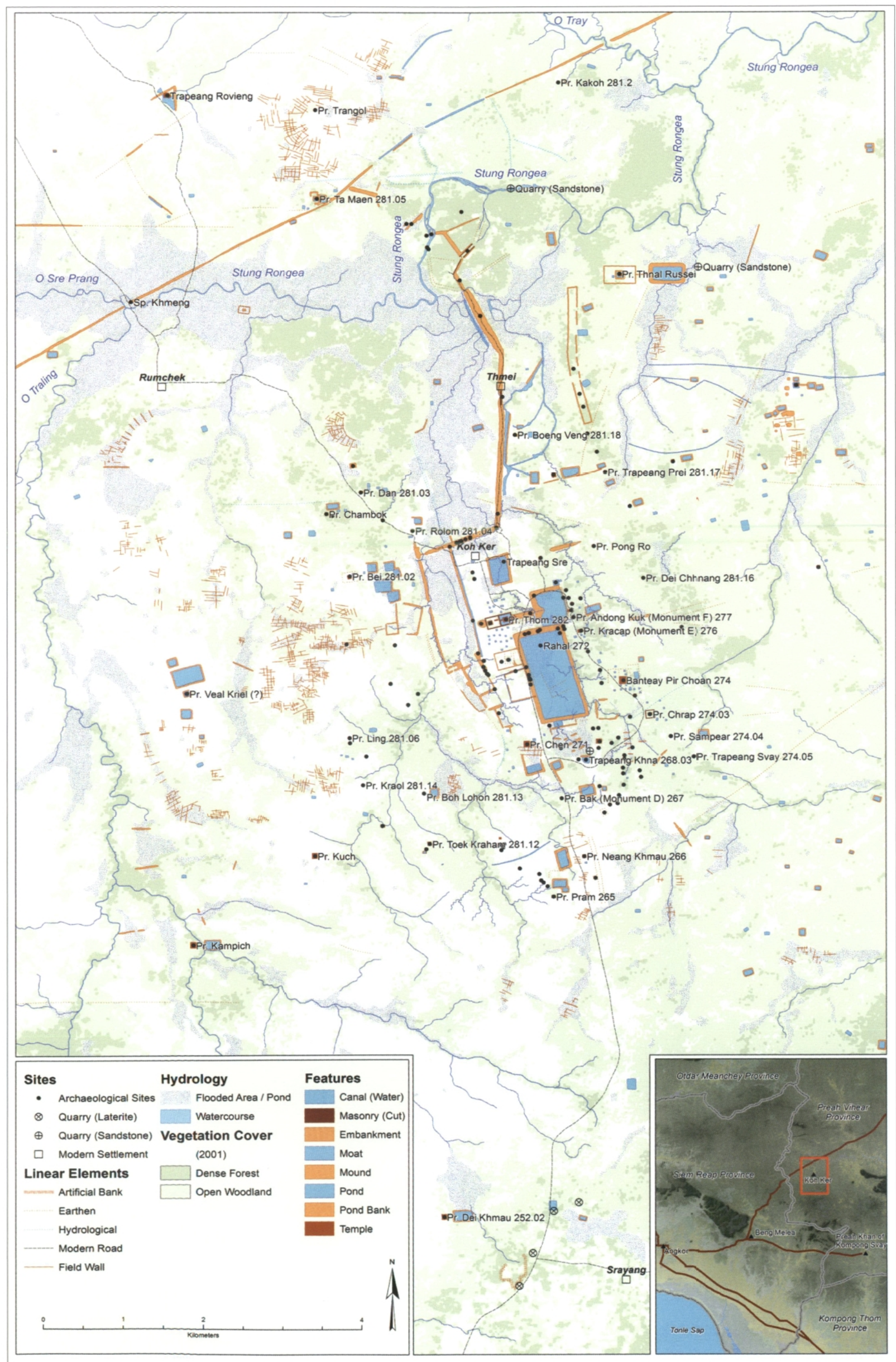


Fig. 7: Quarries at Koh Ker and beyond.

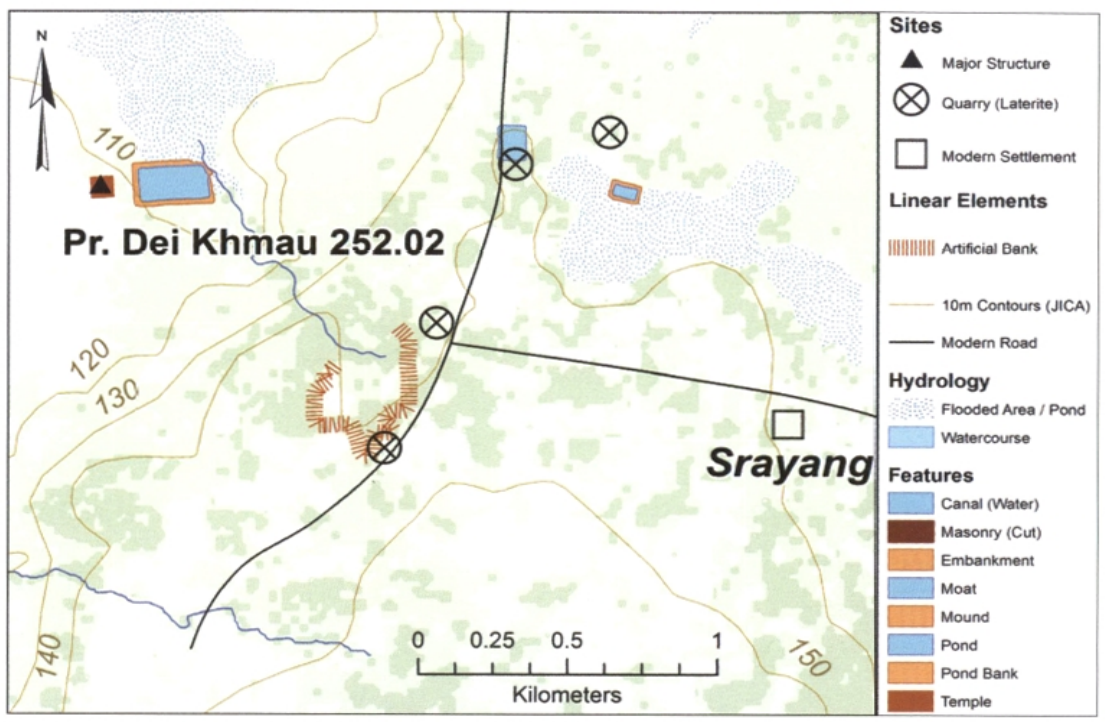

A map of laterite quarries near Srayang \& Pr. Dei Khmau.

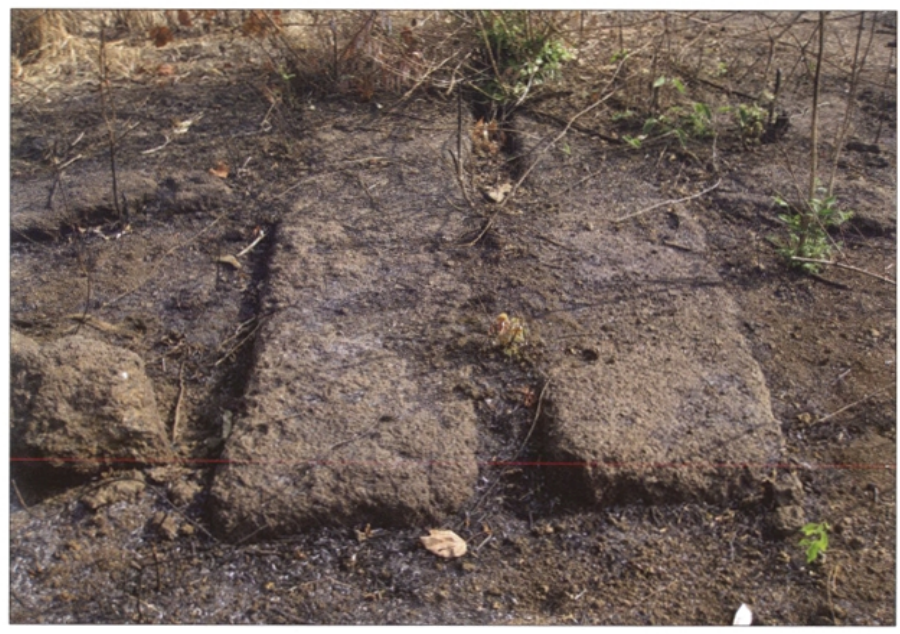

Laterite quarries near Srayang.

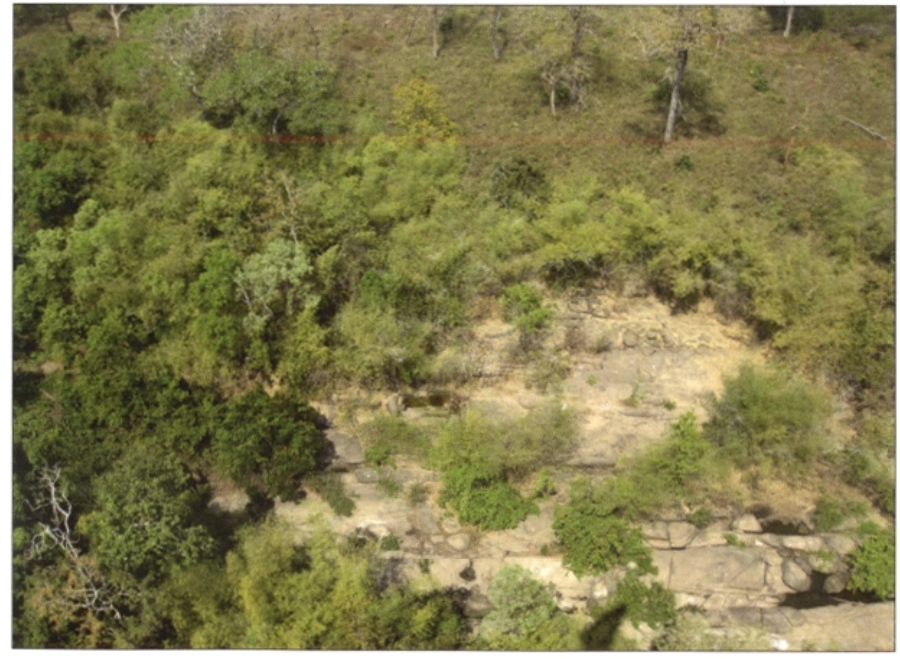

Aerial view of pit quarry area in the sandstone riverbed of the Stung Rongea. 


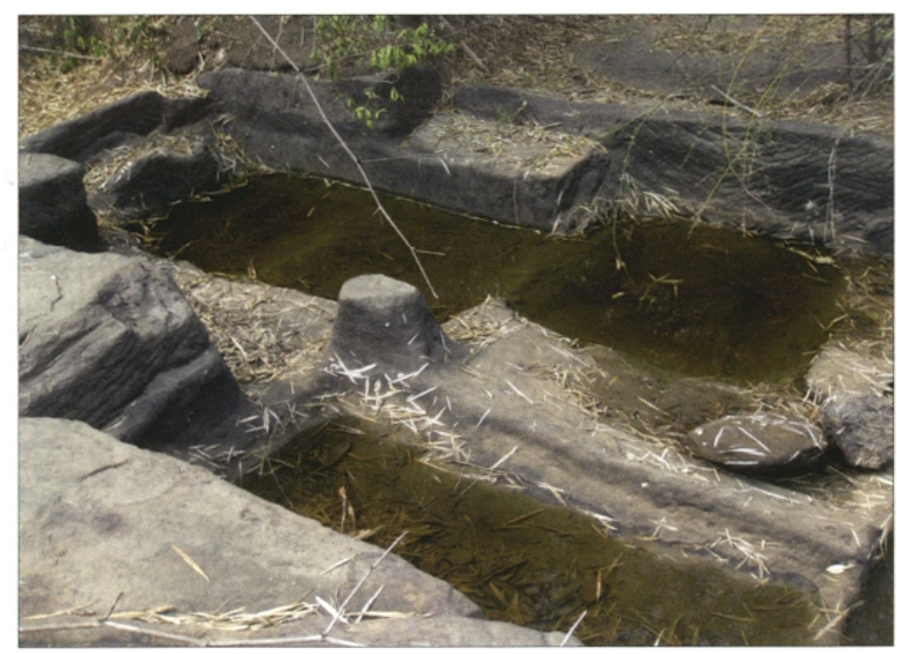

Pit quarry in the Stung Rongea.

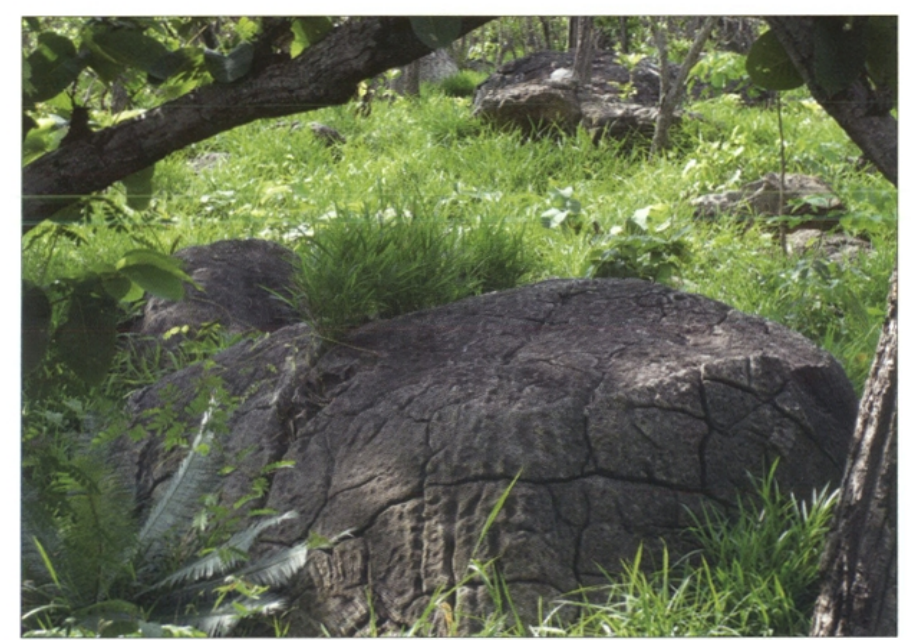

Boulder splitting quarry to the northeast of Banteay Chhmar.

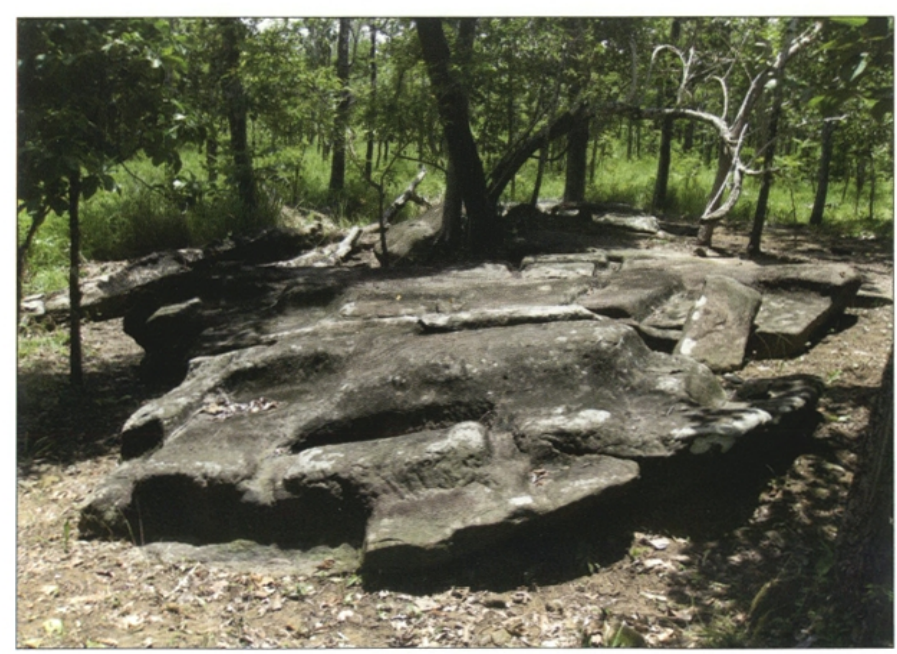

Boulder splitting and channelling at the Trapeang Khna quarry. 


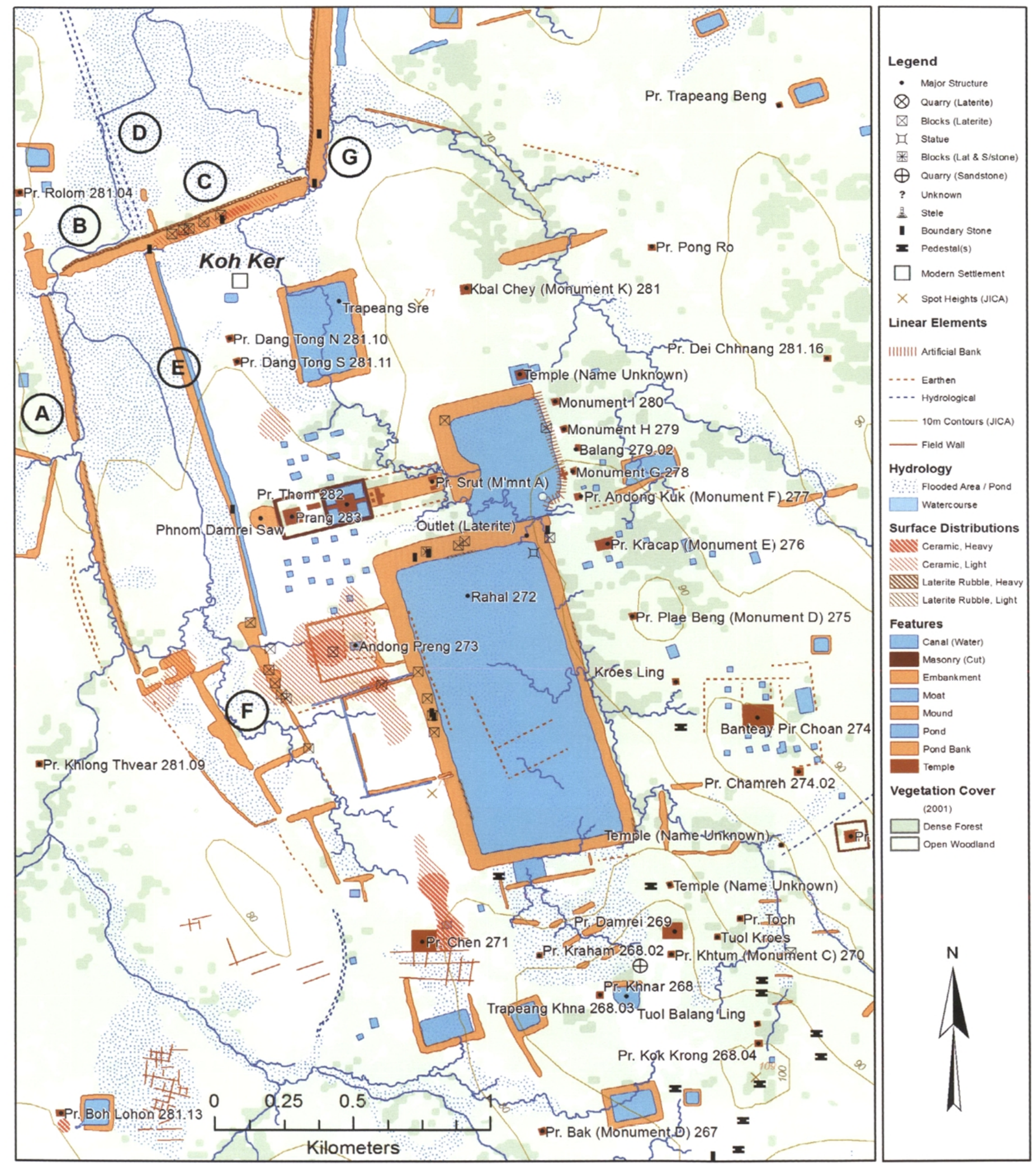

Fig. 8: Detailed map of the Rahal area \& the dykes to the north. 


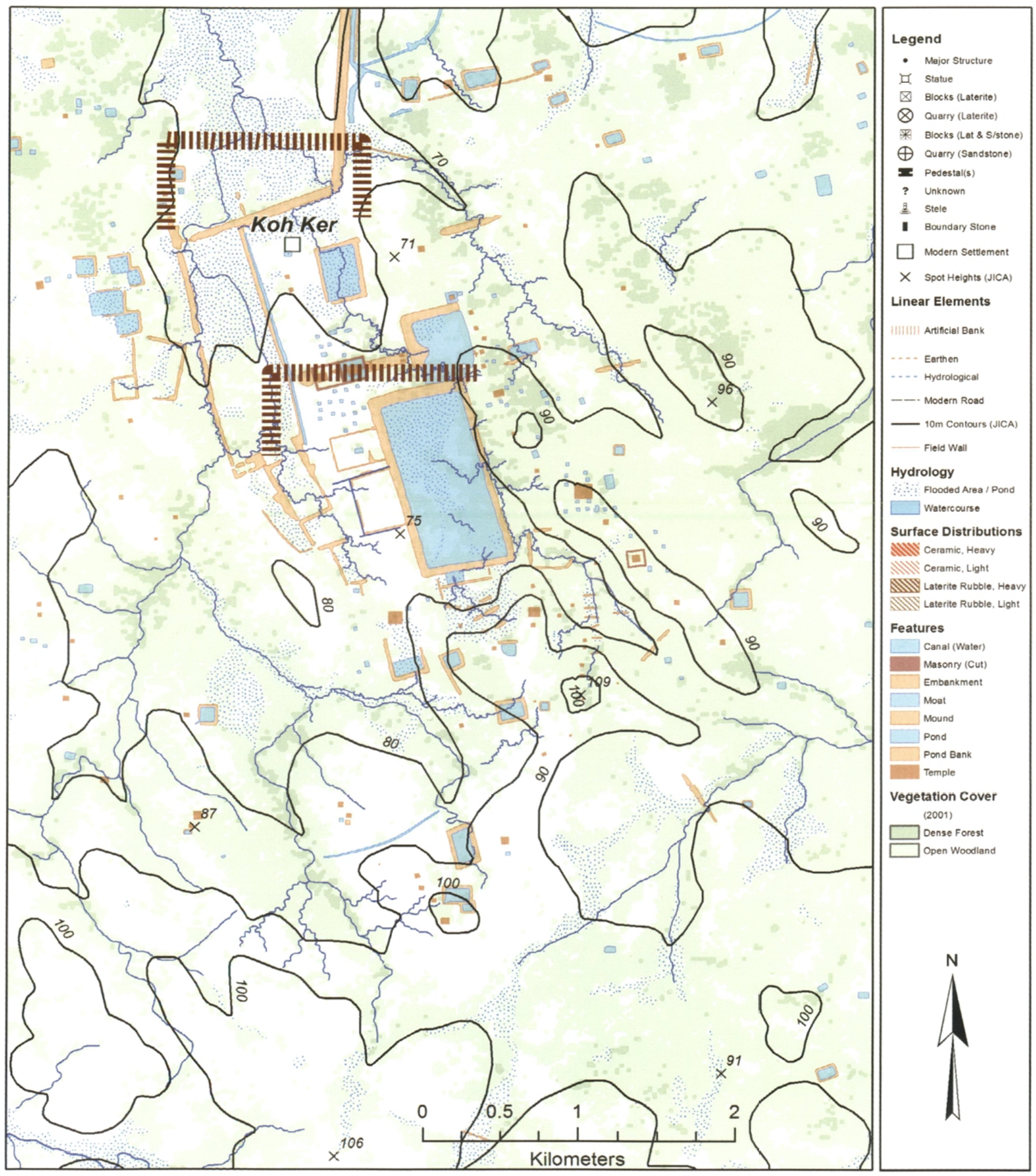

Fig. 9: Alternative and far more effective locations for the Rahal. of similar dimensions and conforming more closely to the 'classic' model of an east-west oriented Angkorian baray. 


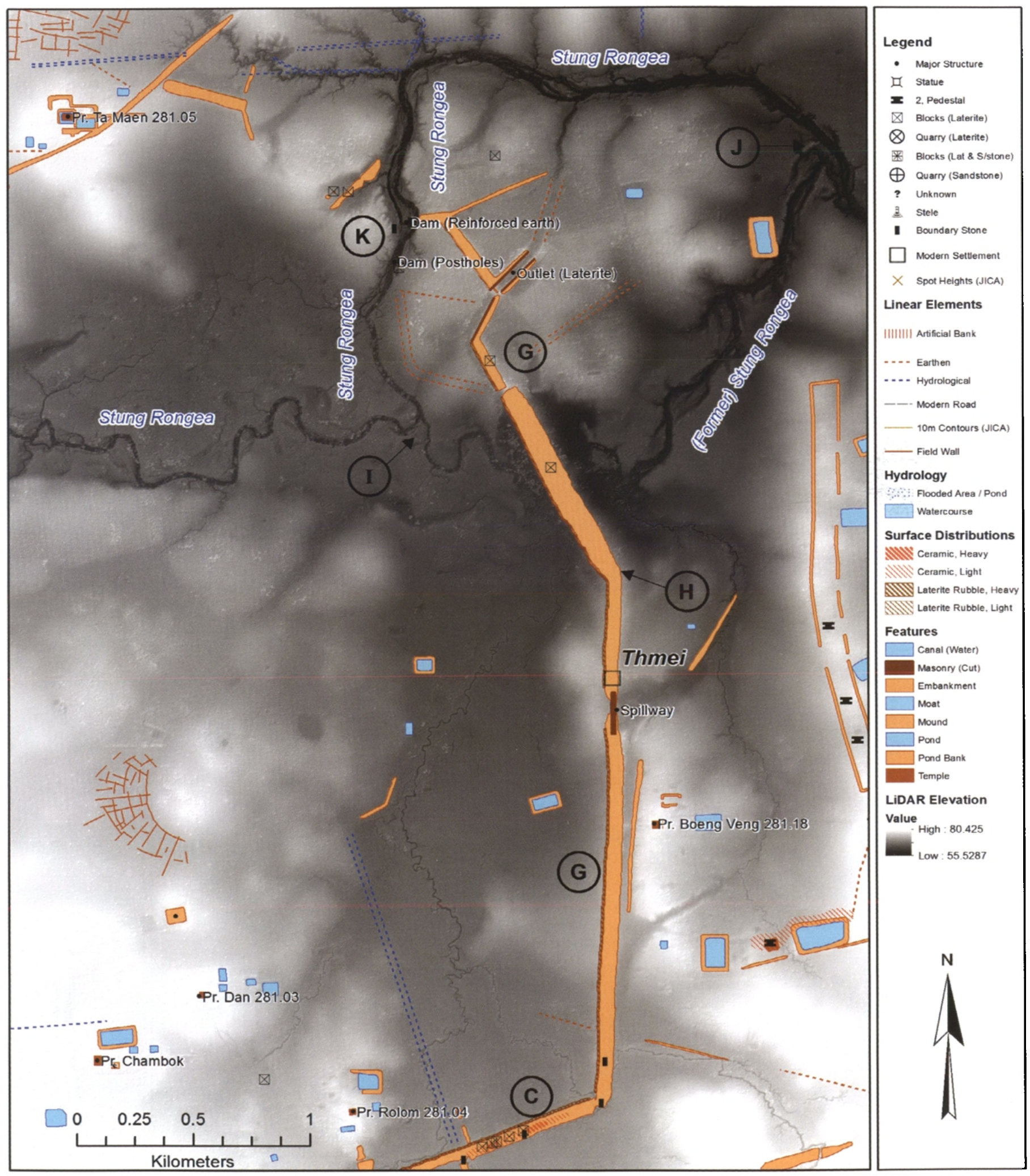

Fig. 10: The northern dam of Koh Ker. and changes to the natural hydrology (background elevation data courtesy of the Khmer Archacology LiDAR Consortium). 


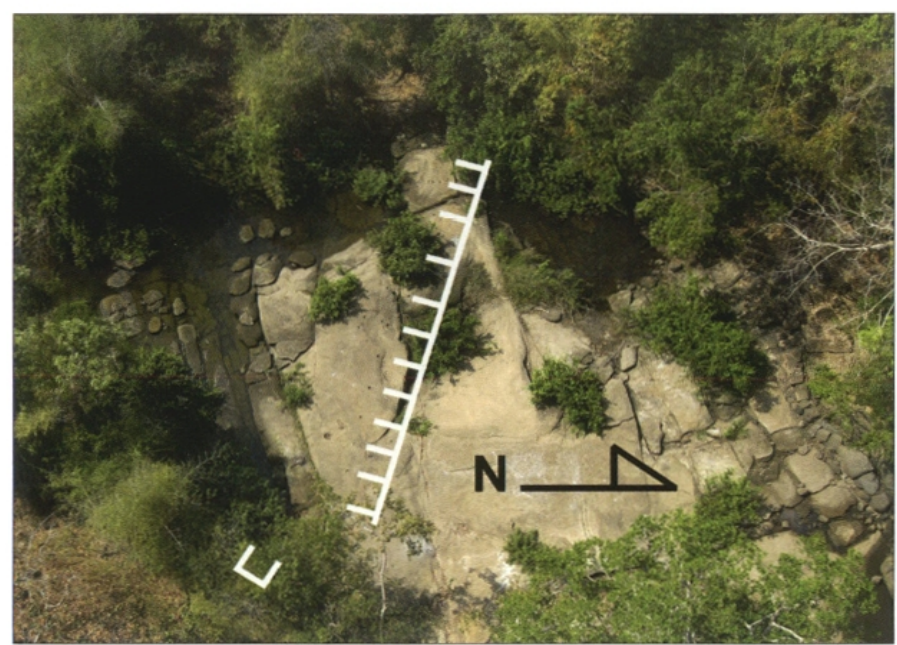

Fig. 11: lilements of the northern dam at Koh Ker.

A line of postholes carved in the river bed of the Stung Rongea, with the location of the buttress marked at bottom (on the east bank).

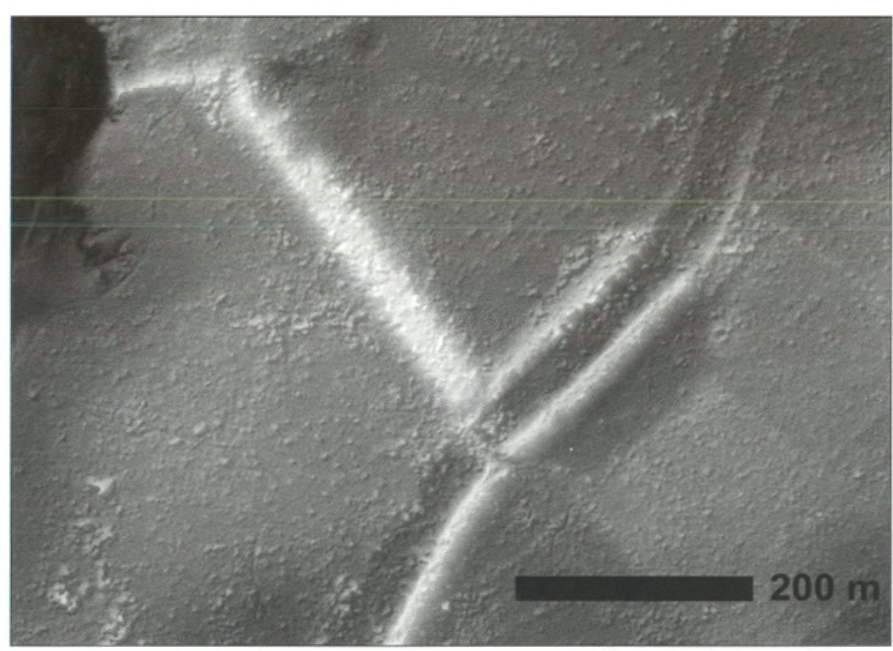

Elevation profile of the outlet structure using lidar elevation data with vegetation filtered from view.

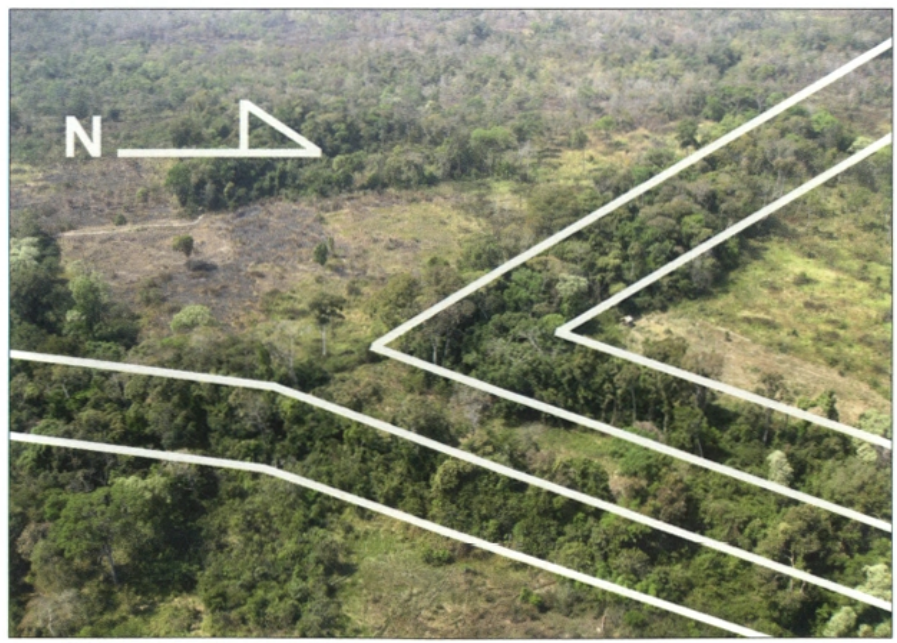

Aerial view. looking to the east, of the parallel-walled outlet structure. 


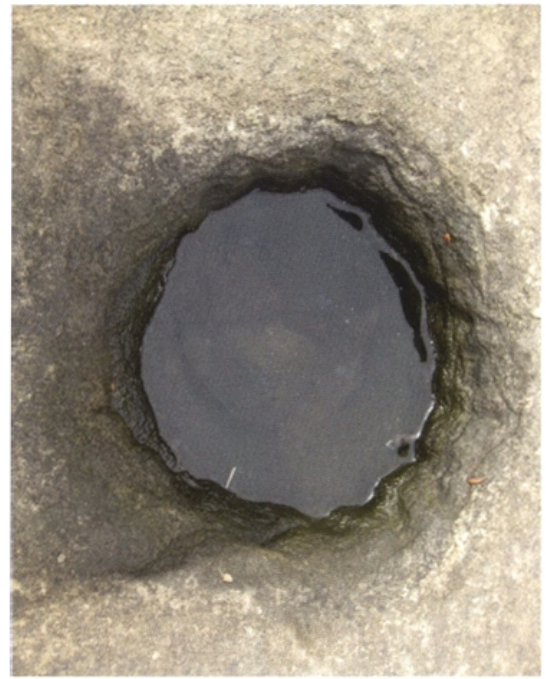

A detail of one of the postholes, showing chisel marks.

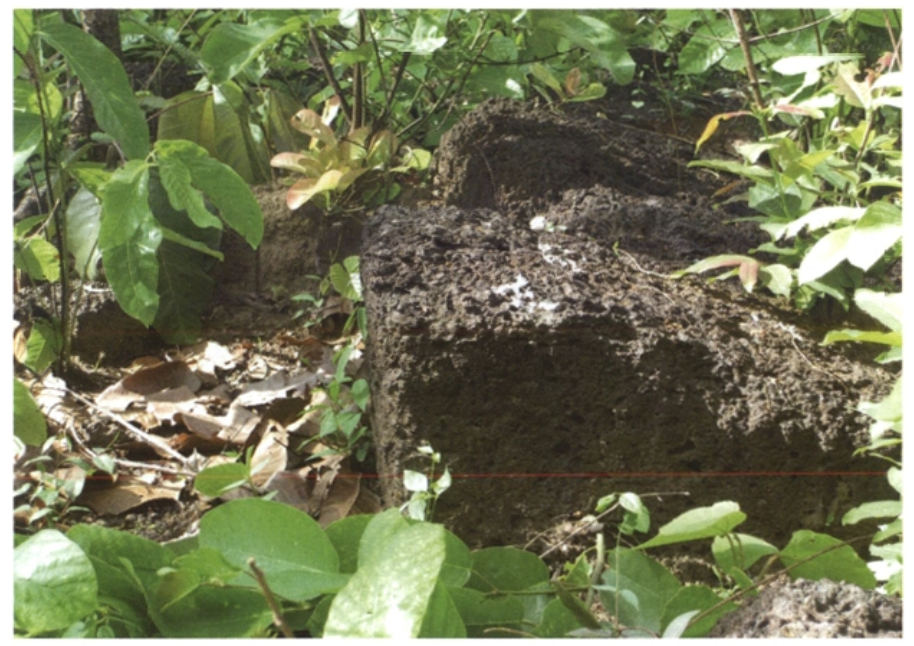

An obliquely carved laterite block of the spillway sloping to the east (to right of the photo).

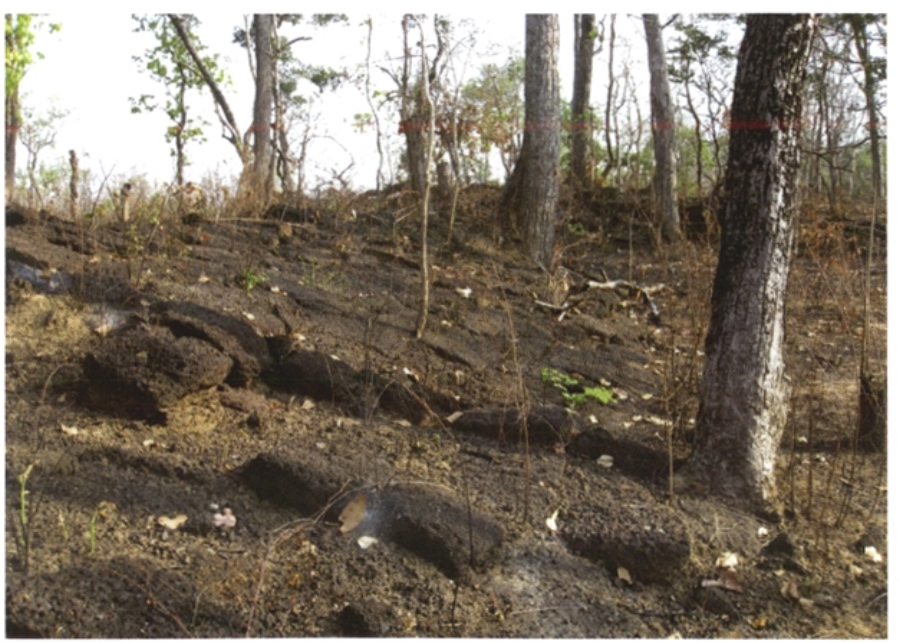

Spillway on the east bank of embankment (G) sloping to the east (to right of photo). 


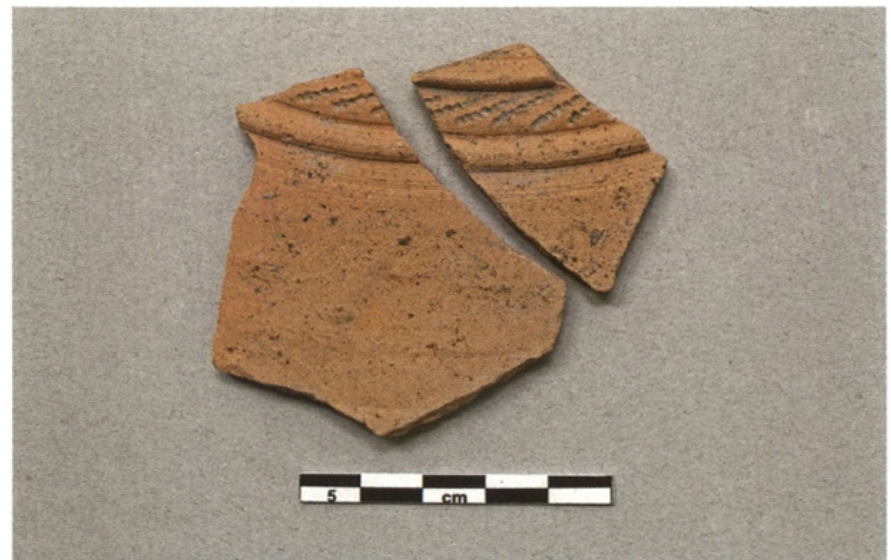

Fig. 12: Surface ceramic finds from various dates.

Pre-Angkorian earthenwares from Prei Khmeng, in the Angkor area (photo courtesy C. Pottier)

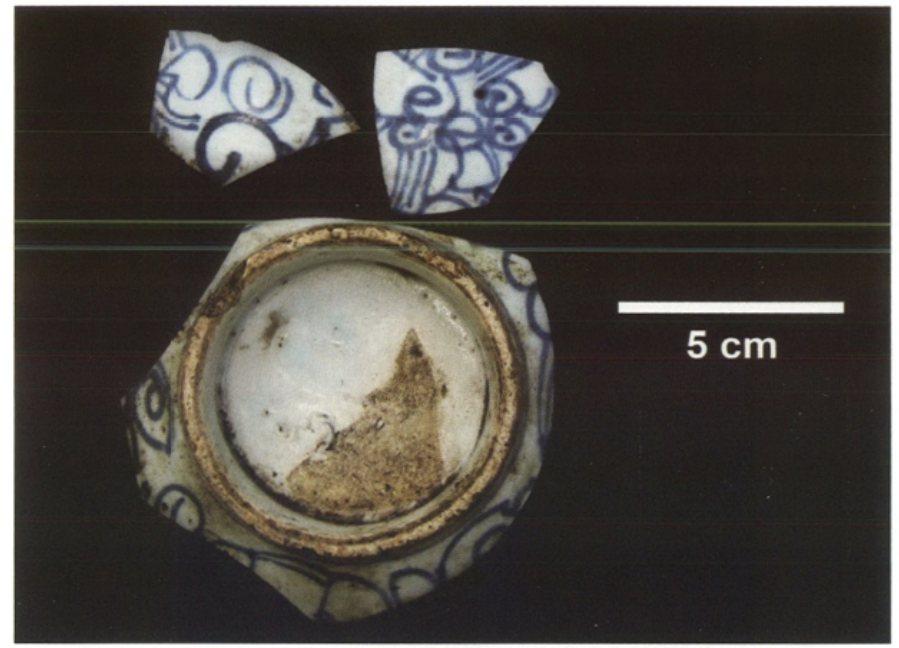

Qing Dynasty ware from Andong Preng.

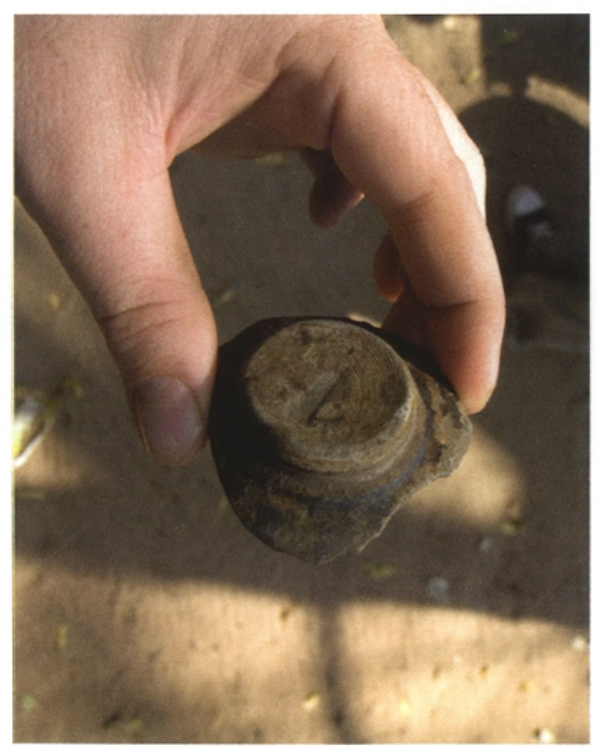

Typical brown glaze ware, from Andong Preng. 


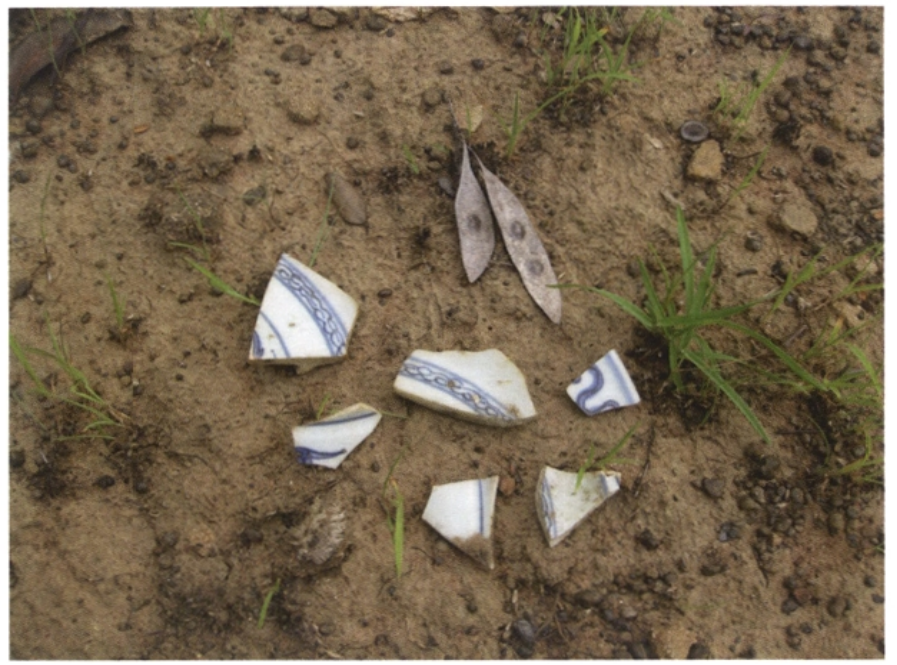

Late Ming Dynasty Chinese ware from the series of embankments marked $(F)$ in Figure 8.

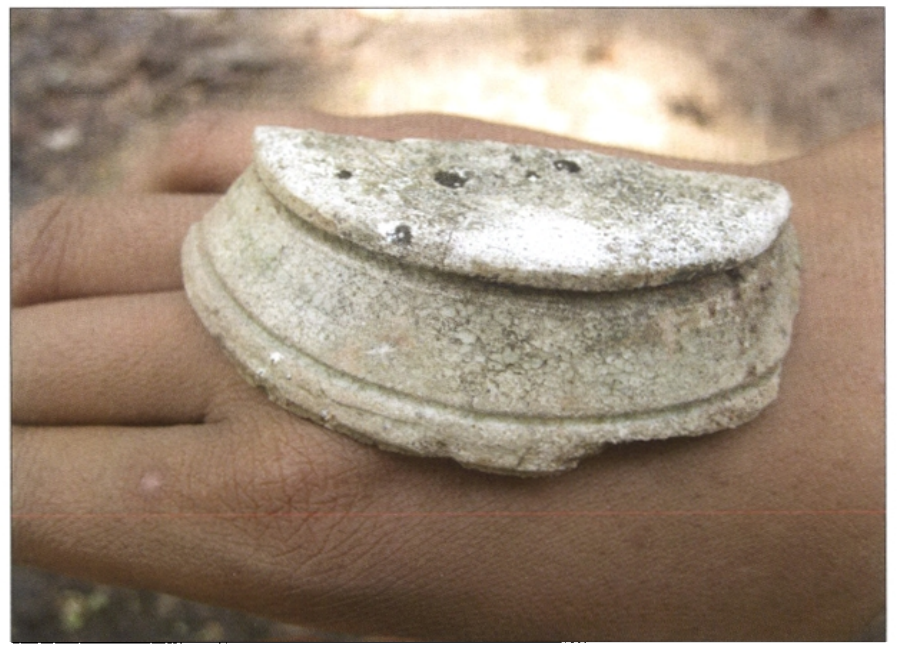

Typical green-glaze or 'Kulen ware', from Andong Preng.

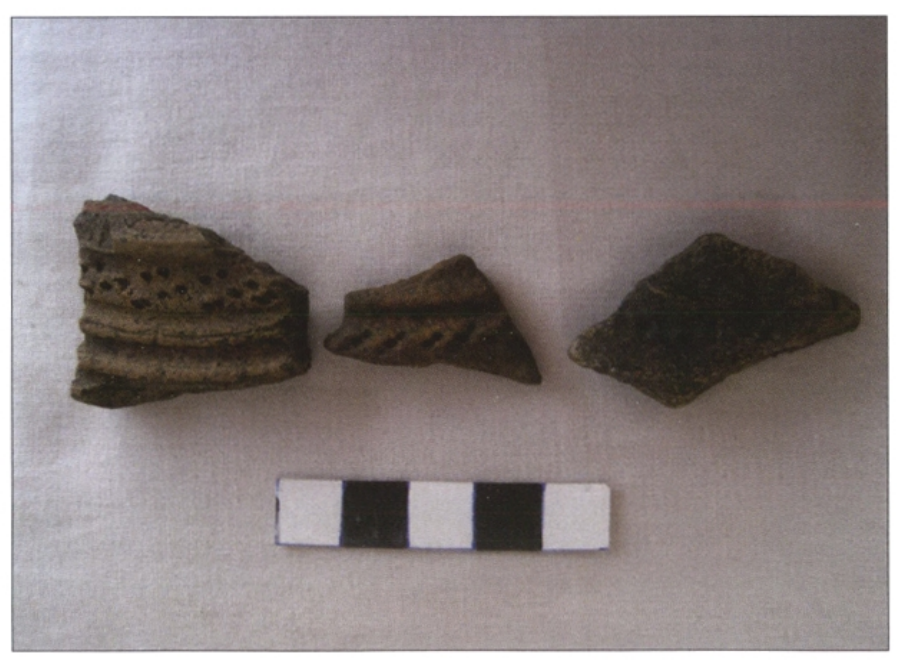

Pre-Angkorian earthenwares from Prasat Boh Lohon (photo courtesy Koh Ker Project). 